\title{
FINANCING FOR DEVELOPMENT IN VIETNAM \\ After International Development Association (IDA) graduation
}

As Vietnam graduates from IDA, the World Bank's concessional finance window, there will be a major change in the types of development finance the country can access. Oxfam is concerned about what this changing financial landscape might mean for Vietnam's fight against poverty, inequality, and gender inequality. This discussion paper explores these challenges by assessing the relationship between official development assistance and the resources needed to support public services, civil society organizations, and avoiding debt. The paper offers recommendations to the World Bank, bilateral donors, the global community, and the Vietnamese government.

\section{Oxfam Discussion Papers}

Oxfam Discussion Papers are written to contribute to public debate and to invite feedback on development and humanitarian policy issues. They are 'work in progress' documents, and do not necessarily constitute final publications or reflect Oxfam policy positions. The views and recommendations expressed are those of the author and not necessarily those of Oxfam.

For more information, or to comment on this paper, email Tariq.Ahmad@oxfam.org 


\section{CONTENTS}

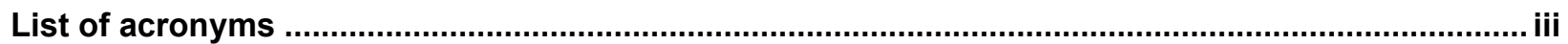

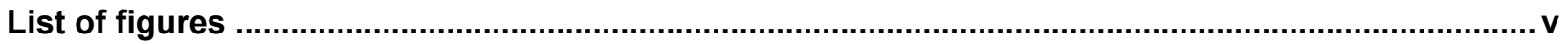

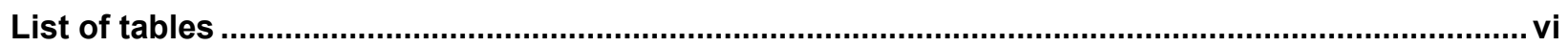

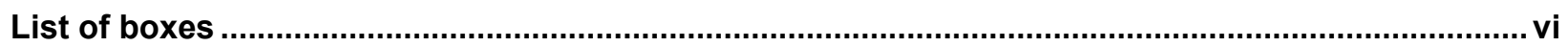

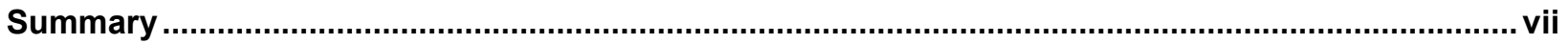

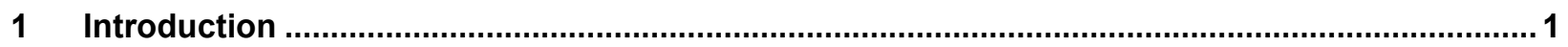

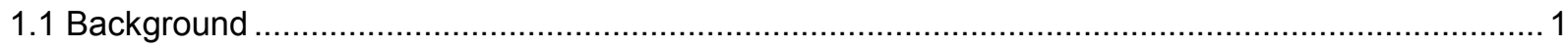

1.2 Country focus, methodology and main research questions .................................................. 3

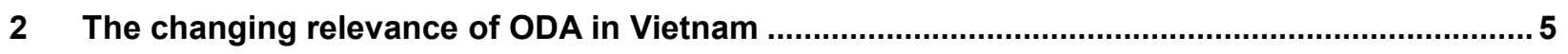

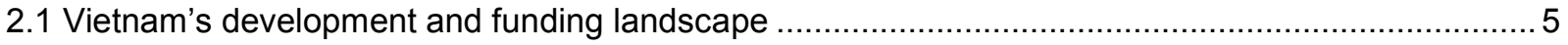

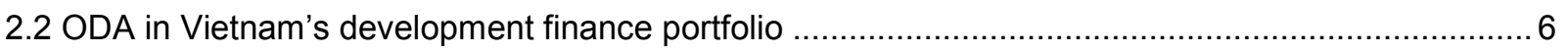

2.3 Multilateral and bilateral ODA donors to Vietnam ................................................................. 10

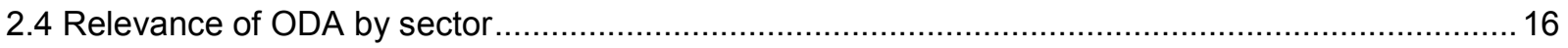

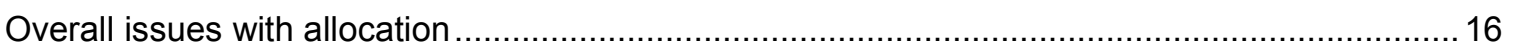

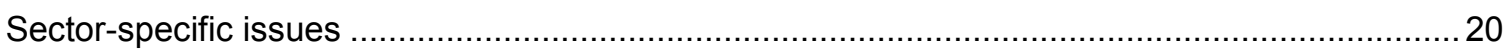

2.5 How is the Vietnamese government adapting to the decrease in concessional finance? ...............27

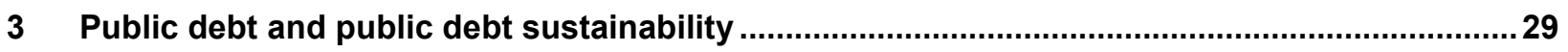

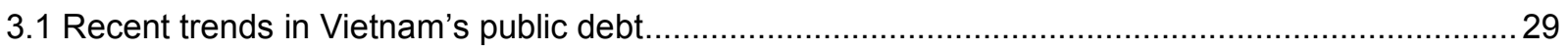

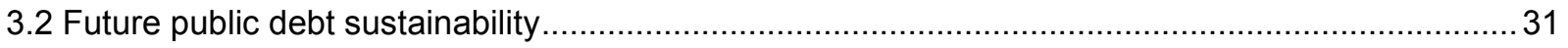

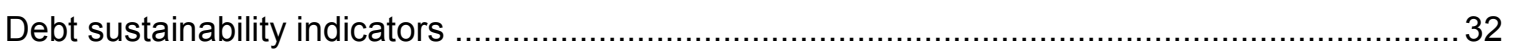

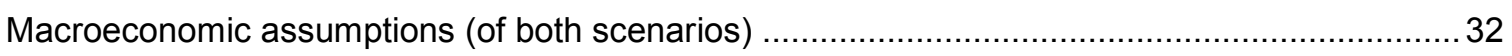

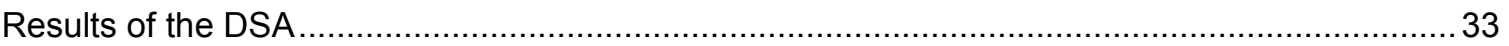

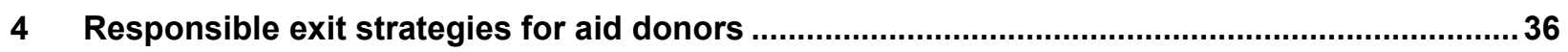

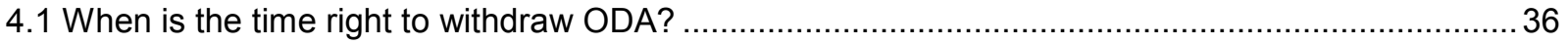

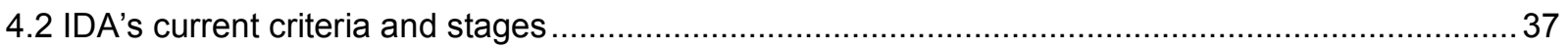

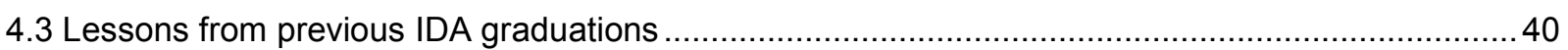

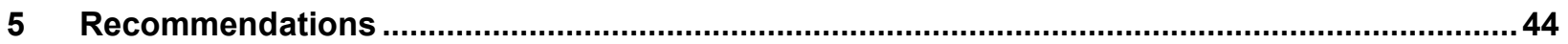

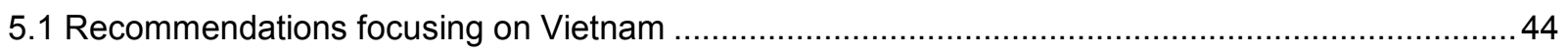

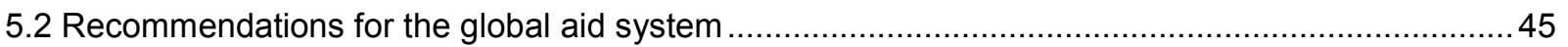

Annex I: Snapshot of Vietnam's recent development........................................................................ 47

Annex II: Recent trends in private external development finance .................................................64

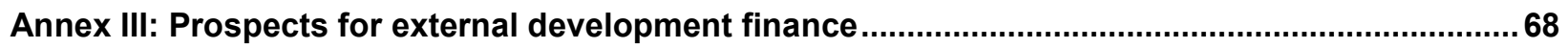

Annex IV: Vietnam's domestic development finance portfolio ...........................................................77

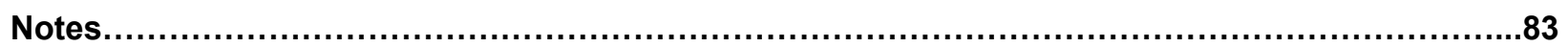




\section{LIST OF ACRONYMS}

$\begin{array}{ll}\text { ADB } & \text { Asian Development Bank } \\ \text { ADF } & \text { Asian Development Fund } \\ \text { ASEAN } & \text { Association of Southeast Asian Nations } \\ \text { ATI } & \text { Addis Tax Initiative } \\ \text { CFBA } & \text { Committee of Finance and Budget Affairs } \\ \text { CIT } & \text { corporate income tax } \\ \text { CPA } & \text { country programmable aid } \\ \text { CPF } & \text { country partnership framework } \\ \text { CSOs } & \text { civil society organizations } \\ \text { DAC } & \text { Development Assistance Committee } \\ \text { DFID } & \text { Department for International Development } \\ \text { DRM } & \text { domestic resource mobilization } \\ \text { DSA } & \text { debt sustainability analysis } \\ \text { DSF } & \text { debt sustainability framework } \\ \text { ECOSOC } & \text { Economic and Social Council } \\ \text { EIB } & \text { European Investment Bank } \\ \text { EU } & \text { European Union } \\ \text { FDI } & \text { foreign direct investments } \\ \text { FfD } & \text { Financing for Development } \\ \text { FY } & \text { fiscal year } \\ \text { GDP } & \text { gross domestic product } \\ \text { GNI } & \text { gross national income } \\ \text { GoV } & \text { Government of Vietnam } \\ \text { HDI } & \text { Human Development Index } \\ \text { HIV } & \text { human immunodeficiency virus } \\ \text { HLM } & \text { High Level Meeting } \\ \text { IBRD } & \text { International Bank for Reconstruction and Development } \\ \text { ICT } & \text { information and communication technology } \\ \text { IDA } & \text { International Development Association } \\ \text { IDS } & \text { international debt statistics } \\ \text { IFC } & \text { International Finance Corporation } \\ \text { IHDI } & \text { Inequality-adjusted Human Development Index } \\ \text { IMF } & \text { International Monetary Fund } \\ \text { INGO } & \text { international nongovernmental organization } \\ \text { ISDS } & \text { Institute for Social Development Studies } \\ \text { ITAIS } & \text { Integrated Tax Administration Information System } \\ \text { ITC } & \text { International Tax Compact } \\ \text { JICA } & \text { Japan International Cooperation Agency } \\ \text { KfW } & \text { Kreditanstalt für Wiederaufbau } \\ \text { LDC } & \text { least developed country } \\ \text { LIC } & \text { low-income country } \\ \text { LMIC } & \text { multilateral development bank } \\ \text { MDB } & \text { MDGs }\end{array}$




$\begin{array}{ll}\text { MIC } & \text { middle-income country } \\ \text { MoF } & \text { Ministry of Finance } \\ \text { MPI } & \text { Ministry of Planning and Investment } \\ \text { MTIP } & \text { Medium Term Investment Plan } \\ \text { NAP } & \text { National Action Plan } \\ \text { NPV } & \text { net present value } \\ \text { OCR } & \text { ordinary capital resources } \\ \text { ODA } & \text { official development assistance } \\ \text { ODI } & \text { Overseas Development Institute } \\ \text { OECD } & \text { Organization of Economic Co-operation and Development } \\ \text { OOF } & \text { other official flows } \\ \text { PI } & \text { portfolio equity investment } \\ \text { PISA } & \text { Programme for International Student Assessment } \\ \text { PIT } & \text { personal income tax } \\ \text { PNG } & \text { private non-guaranteed } \\ \text { PPG } & \text { public and publicly guaranteed } \\ \text { PPP } & \text { purchasing power parity } \\ \text { SDGs } & \text { Sustainable Development Goals } \\ \text { SEDP } & \text { Socio-Economic Development Plan } \\ \text { SEDS } & \text { Socio-Economic Development Strategy } \\ \text { SOEs } & \text { state-owned enterprises } \\ \text { TAMP } & \text { Tax Administration Modernization Project } \\ \text { TIC } & \text { total investment capital } \\ \text { TIWB } & \text { Tax Inspectors Without Borders } \\ \text { UHNWI } & \text { ultra-high-net-worth individual } \\ \text { UMIC } & \text { upper-middle-income country } \\ \text { UN } & \text { United Nations } \\ \text { UNCTAD } & \text { United Nations Conference on Trade and Development } \\ \text { UNDP } & \text { United Nations Development Program } \\ \text { \$ } & \text { United States dollar } \\ \text { USAID } & \text { United States Agency for International Development } \\ \text { VASS } & \text { Vietnam Academy of Social Sciences } \\ \text { VAT } & \text { value-added tax } \\ \text { VBSP } & \text { Vietnam's Bank for Social Policies } \\ \text { VND } & \text { Vietnamese Dong } \\ \text { WBG } & \text { World Bank Group } \\ \text { WEF } & \text { World Economic Forum } \\ \text { WDI } & \text { World Development Indicators } \\ \text { WDR } & \text { World Development Report } \\ \text { WTO } & \text { World Trade Organization } \\ & \end{array}$




\section{LIST OF FIGURES}

Figure 1: The citizen-state compact

Figure 2: Total net ODA to Vietnam, 1990-2016

Figure 3: Actual and projected net ODA, 2012-2019

Figure 4: ODA relative to government expenses, gross capital formation, and TIC

Figure 5: ODA by type of provision, 2008-2016

Figure 6: Disbursements of ODA from IDA (\$ million), 1990-2018

Figure 7: Concessional and non-concessional borrowing from the World Bank (\$ million), 1990-2018

Figure 8: Gross and net disbursements on multilateral loans, 1990-2016

Figure 9: Bilateral net aid flows from Japan and all DAC donors (\$ million), 1990-2016

Figure 10: Bilateral net aid flows from major DAC donors (\$ million), excluding Japan, 1990-2016

Figure 11: Average annual ODA by sector ( $\$$ million and percent), based on 2011-2015

Figure 12: ODA by sector committed for 2016 ( $\$$ million and percent)

Figure 13: Gross disbursements of ODA by sector for all donors and IDA (percent of total), average for 2008-2016

Figure 14: Changes in the allocation of ODA to sectors over time (percent), 2008-2016

Figure 15: Prevalence of stunted height for children under five (percent), all available years

Figure 16: Percentage of people with access to safe water and sanitation, 2000-2015

Figure 17: Gross disbursements of ODA for agriculture (\$ million), 2008-2016

Figure 18: Evolution of PPG debt (\$ billions and percent of GDP), 2012-2016

Figure 19: Interest payments on PPG debt (percent of GDP and revenues), 2012-2016

Figure 20: Results of the DSA with zero concessional debt by 2030

Figure 21: Results of the DSA when keeping the level of concessionality as in 2015

Figure 22: IDA stages

Figure 23: Evolution of annual GDP growth and GDP per capita growth, 1990-2016

Figure 24: Sources of Vietnam's GDP growth

Figure 25: Evolution of Vietnam's HDI compared with Bolivia's and Sri Lanka's, 1990-2015

Figure 26: Growth rate of Vietnam's HDI (percent), 1991-2015

Figure 27: Evolution of income poverty (all available years)

Figure 28: Evolution of income poverty (in terms of millions of people)

Figure 29: Evolution of income inequality (measured by Gini Index)

Figure 30: Evolution of income shares of top and bottom 10 percent, 1992-2014

Figure 31: Evolution of number of UHNWIs

Figure 32: Evolution of HDI and IHDI, 2010-2015

Figure 33: Inequality in human development and income inequality, 2010-2015

Figure 34: Vietnam's score in the WEF's Global Gender Gap Index, 2007-2017

Figure 35: Comparison of women in the labor force across countries around 2010

Figure 36: Net transfers on PPG external debt by creditor (\$ million), 1990-2016

Figure 37: FDI, PI, remittances, and net transfers on PPG and PNG external debt (\$ million), 1990-2016

Figure 38: Government expenditures, revenues, and tax revenues (percent of GDP)

Figure 39: General government revenue (percent of GDP) of Bolivia, Sri Lanka, and Vietnam

Figure 40: CIT rates in selected economies (percent) 


\section{LIST OF TABLES}

Table 1: ODA by sector in Vietnam, Bolivia, and Sri Lanka (based on 2016 commitments)

Table 2: Indicative World Bank lending to Vietnam, FY2018-FY2020 (\$ million)

Table 3: Donor contributions to the education sector (based on 2016 commitments)

Table 4: Donor contributions to the health sector (based on 2016 commitments)

Table 5: Donor contributions to the water sector (based on 2016 commitments)

Table 6: Net ODA projections for 2017-2019 (based on CPA) in \$ million, unless otherwise indicated

Table 7: Focus areas and objectives of the World Bank's CPF for Vietnam

\section{LIST OF BOXES}

Box 1: IDA's eligibility criteria

Box 2: A gradual transition away from IDA

Box 3: Lessons from Indonesia's IDA graduation (Prizzon et al. 2017)

Box 4: CPA for Vietnam, Bolivia, and Sri Lanka, 2012-2019

Box 5: New DAC rules on sovereign loans from DAC members being counted as ODA

Box 6: The Journey to Self-Reliance-USAID's new strategic approach

Box 7: Government revenues in Bolivia, Sri Lanka, and Vietnam 


\section{SUMMARY}

On July 1, 2017, Bolivia, Sri Lanka, and Vietnam officially graduated from the International Development Association (IDA). This means that, based on current World Bank rules, these countries have lost access to concessional finance (loans and grants) from IDA. They may soon also have decreased access to concessional finance from other donors too. In one sense, IDA graduation is good news for a country, because it signals that significant economic growth has occurred. However, the loss of access to concessional financing can also cause considerable challenges and risks for a country, as middle-income status is often accompanied by social dislocation, governance limitations, and inequalities in the distribution of economic gains.

The World Bank has been grappling with how to ensure the IDA graduation process is responsible and sustainable, recognizing the challenges that graduation causes countries. In fact, World Bank officials indicate there have already been important changes to graduation criteria, with internal assessments of a variety of country dynamics now informing graduation decisions. And, while the actual graduation from IDA formally takes place according to the World Bank annual cycle, removing access to IDA finance and benefits may take place more gradually. (See Box 1 and 2 for more details.)

Meanwhile, following the 2017 High Level Meeting (HLM) Communiqué of the Development Assistance Committee (DAC), other donors have also been thinking about how to responsibly withdraw aid from countries. The Communiqué called for a review of the consequences of different transition processes on access to development finance from all sources. It is anticipated that, in 2019, the DAC will provide shared guidance for all donors on the approach to take for countries transitioning away from a relationship that has been largely based on official development assistance (ODA). Furthermore, there is an additional DAC mandate to promote a future in which no country depends on aid. Similarly, the United States Administration for International Development (USAID) has strengthened its intent to help countries on their "Journey to SelfReliance" by creating a policy framework to guide sustainable investments.

Oxfam believes that the ultimate purpose of aid is to create a world where aid is no longer necessary. However, aid continues to play a vital role in helping lower- and middle-income countries build institutions, fight poverty and inequality, promote gender equality, encourage good governance, and meet humanitarian needs. While aid on its own is not enough to tackle these problems, it is necessary, particularly when countries do not yet have sufficient sources of domestic revenue or the capacity to carry additional debt.

Oxfam is concerned about the very real risks associated with a country graduating too soon, as it may either result in that country ending up heavily indebted (if concessional development finance is replaced by nonconcessional borrowing) or past progress being threatened (if development projects or essential services are no longer viable due to a lack of funding). The Government of Vietnam (GoV) (2015) has already recognized that reductions in ODA have created difficulties in financing several social and economic activities, particularly in the provision of healthcare for the disadvantaged and reducing poverty. These risks are especially critical in light of growing inequalities as a result of the changing development finance landscape.

Through an examination of the consequences of IDA graduation on Vietnam, we conclude that transition away from aid should be a more gradual process than it is currently, with a slow hardening of the lending terms and transition from concessional to non-concessional finance. Because lower-middle-income countries often have large numbers of people living in poverty and high levels of inequality, a careful analysis of the appropriate mix of concessional and non-concessional financing is needed. We recommend that while IDA graduation can serve as a reference point, it is important to delink withdrawal of non-IDA ODA from the IDA 
graduation process, so other donors continue to add value through financial and technical support where appropriate and feasible. Oxfam recommends a continuation of ODA, but the nature of ODA should change after a careful analysis to determine the appropriate mix of concessional and non-concessional financing. The World Bank and other donors should target concessional funds to programs and policies with a strong focus on fighting inequality, reducing poverty, and building long-term institutional and financial capacity, especially through domestic revenue mobilization.

In order to deliver social services to communities that are most in need, ODA should strengthen the capacity of both state and non-state recipients, including civil society organizations. ODA should also be focused more on increasing civil society-led accountability initiatives. Maintaining support to gender equality initiatives and the provision of resources to women-led organizations is critical in these efforts. Oxfam recognizes that continued concessional finance for lower-middle-income countries could mean fewer concessional grants and loans available for low-income countries. It is therefore extremely important that these scarce resources are deployed as effectively as possible, ensuring that ODA is a catalyst for social and institutional development rather than simply being a source of cash for services and infrastructure that could have been funded through other means, including through domestic revenues and private sector investment, where appropriate.

This report focuses on Vietnam, which is arguably among the countries best-prepared for IDA graduation given its recent growth and poverty reduction record. Yet even so, Vietnam faces many development and governance challenges that would be aggravated if its IDA graduation leads to a sharp decline in access to concessional finance. Exploring these challenges for a well-prepared country sheds light on the scope of challenges for other graduating countries in less-favorable circumstances.

\section{VIETNAM'S CHANGING DEVELOPMENT PORTFOLIO}

Total net ODA to Vietnam increased steadily each year from 1990 to 2014 (reaching a high of $\$ 4.2$ billion in 2014 ), but then declined relatively sharply to $\$ 2.9$ billion in 2016 . The ratio of ODA to GDP has declined during the last two decades from 5.4 percent in 2000 to only 1.4 percent in 2016 , which is largely due to Vietnam's rapid GDP growth. As detailed in Section 2 in the main paper, this growth would not have been achieved without the inflow of aid.

Recent ODA to Vietnam has been spent largely in economic sectors. During 2011-2015, 53 percent of ODA was allocated to the transport, urban, energy, and industrial sectors. On the other hand, agriculture and rural development, health, and education received, respectively, only 9.5 percent, 4.7 percent, and 3.4 percent of total ODA. In 2016, this imbalance became more pronounced, with the percentage of ODA in the above economic sectors increasing to 68 percent. Thus, as total ODA has declined, its allocation has been away from social sectors.

The fact that most of Vietnam's recent ODA has gone to economic projects creates an opportunity for Vietnam, as ODA is more likely to be easily replaced by private sector investment in economic projects than in social sectors. If the private sector can successfully replace ODA in economic sectors, the reduced future ODA can then be focused on social sectors without reducing the amount of ODA in social sectors.

Furthermore, given its reduced availability, the remaining ODA should primarily focus on institutional and financial capacity building (e.g., aid for domestic revenue mobilization) for both government and civil society actors. This will help ensure that less external assistance will be needed in the future. 
During 2011-2013, the share of all donor funds to Vietnam's education budget was a marginal 2.25 percent. At first glance, this appears to suggest that aid is inconsequential in the education sector. However, this ignores the fact that donors have played an important role in stimulating government spending on education, particularly to help reach disadvantaged groups in Vietnamese society. Hence, the further reduction of ODA will threaten Vietnam's education sector, especially as IDA has been the largest donor for education programs by far. The same applies to the water sector.

With regards to promoting gender equality, so far, almost every program in Vietnam has been externally supported. ODA has facilitated changes in this area by bringing in new ideas for reform, promoting certain groups of reform actors in key ministries, and creating evidence for policy dialogue that did not exist before. It would be inappropriate to claim ODA alone contributed to gender equality achievements; however, it has played a big part. According to local gender practitioners, many ODA-financed programs influenced the GoV's policy and decision-making process, which resulted in pro-reform policies, laws, and legal documents. As ODA declines, opportunities for maintaining dialogues could be substantially reduced, risking a loss of momentum for pro-poor policy changes.

The GoV has detailed its intention to focus on the attraction, management, and use of ODA during 20162020 in Decision 251/QD-TTg (February 2016). It states that "Vietnam has advocated mobilization of all resources for development investment of which ODA and concessional loans from foreign donors remain vital [to accomplish the socio-economic development tasks during the 2016-2020 period]." Beyond the stipulations in Decision 251, the recent decline in ODA has been compensated mostly by an increase in domestic borrowing. However, the management of Vietnam's public financial sector is relatively weak and Vietnam's banking sector is vulnerable. This will make it difficult to further mobilize domestic resources for development.

\section{IMPACT ON VIETNAM'S PUBLIC DEBT SUSTAINABILITY}

With a likely decline in the flow of ODA in the future, the GoV will need to rely on other sources of revenue to fill the gap. This could be filled by far more expensive non-concessional financing, which will not only impact the availability of revenues (e.g., through higher interest payments), but also Vietnam's debt sustainability.

Vietnam's long-term public and publicly guaranteed (PPG) external debt reached \$47.1 billion in 2016 . Vietnam's public domestic debt increased from \$34.6 billion in 2012 to an estimated $\$ 78.5$ billion in 2016. Hence, total public debt increased from $\$ 74.5$ billion in 2012 to $\$ 125.6$ billion in 2016 , which is an increase of 68.6 percent in only four years. The increase in public debt, and especially the shift towards nonconcessional domestic public debt, implies that the government will have to spend more and more on debt service and will therefore have fewer and fewer resources available for critical development interventions. Furthermore, the growth rate of total public debt has been considerably higher than the growth rate of GDP.

Using current (2014-2016) macroeconomic indicators, Oxfam projections show that if Vietnam's level of concessional debt gradually decreased from its current level to zero by 2030 , its debt-to-GDP ratio will increase from about 60 percent in 2015 to nearly 90 percent in 2030. The debt service-to-revenue ratio is also projected to increase from 41 percent in 2015 to 75 percent in 2030 under this scenario. On the other hand, if the level of concessional debt remains as it was during 2014-2016, Vietnam's fiscal debt would be sustainable. 
If the GoV wants to keep its debt sustainable, it will need to take at least one of three actions: (1) increase its revenue-to-GDP ratio, (2) decrease its expenditure-to-GDP ratio, and/or (3) stabilize the level of concessionality of its public external debt. Given the difficulty in rapidly increasing domestic tax revenues in an equitable way and a projected decline in trade taxes, it will certainly be challenging for the GoV to rapidly increase its revenue-to-GDP ratio. It is essential, however, that the GoV makes a bold move to do so, as private sector funding is neither sufficient nor appropriate to finance some key services, particularly health and education services. This must be done in a way that does not place the burden on the poorest and most vulnerable populations. There are a number of progressive tax reforms that the GoV could adopt with the right support and political will. The 2018 Commitment to Reducing Inequality Index and Vietnam Fair Tax Monitoring Report 2017 show that while Vietnam's tax structure is generally progressive, it could be improved by increasing corporate taxes; keeping the value-added tax (VAT) steady; strengthening wealth taxation, such as property tax; removing harmful tax incentives, and reducing the level of tax avoidance. ${ }^{1}$

\section{WHEN IS THE RIGHT TIME FOR A COUNTRY TO GRADUATE?}

The seemingly simple answer to the question of when the time is right for a country to graduate from receiving ODA is when (a) poverty has been reduced to an acceptable minimum level in that country, and (b) the loss of ODA will not threaten the progress made. However, determining the exact indicators to use to measure these simple criteria is complicated and controversial.

On the other hand, the current criteria used to determine graduation from IDA, which focus on the level of average gross national income (GNI) per capita and a country's credit worthiness, are much simpler. But the criteria are also unsatisfactory, as average GNI says-due to different levels of inequality-very little about poverty in a country. The World Bank does use other analyses to determine the graduation criteria, but reaching a specific level of GNI per capita and creditworthiness are the primary indicators. Only if there is no inequality would average GNI per capita be a useful indicator for poverty. Inequality-adjusted Human Development Index (HDI) would be a far better indicator, shifting the focus of development from national income accounting to people-centered policies.

IDA and its donors should re-evaluate the policy on how to determine a country' readiness to graduate and what type of support should be prioritized as concessional finance contributions to a given country diminish.

\section{WHAT CAN WE LEARN FROM PREVIOUS GRADUATIONS?}

Since IDA was established in 1960, 44 countries have graduated from IDA. However, nine of these 44 graduates (20.4 percent) have since re-entered IDA, which supports the argument that IDA graduation can happen prematurely. In some cases, the re-entry point was decades after graduation, as with Nigeria and Côte d'Ivoire.

The United Nations Economic and Social Council (ECOSOC)'s Financing for Development Follow-up in April 2018 acknowledged that ODA and other concessional finance are still important for a number of middleincome countries. These discussion on graduation perhaps come too late for Vietnam, but they are critical for the next cohort of graduates and those that come after them. 


\section{RECOMMENDATIONS RELATED TO VIETNAM}

The first key recommendation is that Vietnam continues to receive ODA in order to improve the capacity and responsiveness of institutions that provide social services, as the provision of these services is not suited to commercial loans and is unlikely to be funded sufficiently from domestic revenues in the medium term. The second key recommendation is that ODA provided to Vietnam could be more effective by revising government regulations on ODA. Third, the effectiveness of ODA should be enhanced by decentralizing aid to include both state and non-state recipients, including established civil society organizations, to more effectively reach people and communities that still have high levels of poverty. Fourth, Vietnam should make use of the wide range of complementary development finance mechanisms available (e.g., domestic revenue mobilization, foreign direct investment, remittances, etc.), which if effectively tapped will help Vietnam achieve the SDGs without threatening its fiscal debt sustainability. Fifth, given that the international financial system is prone to crisis, Vietnam needs to be more proactive in shaping and implementing crisis prevention strategies at both the regional and international level. Finally, given that Vietnam is one of five coastal developing countries most affected by climate change, it needs to increase its efforts to mainstream its climate change response.

\section{RECOMMENDATIONS FOR THE GLOBAL AID SYSTEM}

IDA needs to adjust its graduation process transparently, reflecting the indicators and data available today. The GNI per capita indicator was useful in the last century, but it is long overdue to be replaced by a combination of poverty and social indicators. While the World Bank uses a variety of other indicators and assessments to determine IDA graduation readiness, the discussions are primarily driven by the GNI per capita threshold. Moving forward, donors should base their ODA transition on comprehensive development indicators, including inequality and gender inequality, not only on national income accounting indicators. At a minimum, the income per capita criterion should be replaced with the inequality-adjusted HDI, which has been reported annually for almost every country since 2010. All of these changes should be made and communicated transparently. Development partners should also affirm that meeting the SDGs is the operational objective for the allocation of aid, with country-level SDG-based poverty reduction strategies at the heart of development support based on a combination of needs and aid effectiveness criteria.

Thorough transition plans, in which downside risks are carefully weighed, are crucial. IDA transition periods should be extended beyond the current timeframe, ensuring a gradual decline in access to concessional financing (instead of such financing peaking shortly before graduation) that is responsive to the country context including inequality and more comprehensive development indicators. Furthermore, there is room to better coordinate ODA transition strategies across donors. The recent focus on private sector involvement in aid should not distract from the need to use ODA for priority public investments in social sectors. Directing ODA to social sectors will maximize progress in achieving the SDGs in sectors for which private sector involvement is either not possible or risks having a negative impact on poverty and inequality (e.g., via user fees). Supporting sectors and programs that are most vulnerable to a decline in aid should be the priority for future ODA, along with building institutional and financial capacity (e.g., through aid for domestic revenue mobilization). ${ }^{1}$ 



\section{INTRODUCTION}

\subsection{BACKGROUND}

The global development finance landscape is shifting quickly as Official Development Assistance (ODA) becomes a less prominent financial flow to developing countries. The global development community is wrestling with what this means for resources devoted to fight poverty, economic inequality, and gender inequality, considering that ODA has played a critical role in financing these efforts to date.

A key milestone that affects a country's ability to finance development is the graduation from lowincome country (LIC) status to lower-middle-income country (LMIC) status, and the country's subsequent loss of qualification for highly concessional finance from various donors, especially from the International Development Association (IDA), the concessional lending arm of the World Bank. In the 39 poorest countries in Africa, IDA is the single largest source of donor funds for basic social services, demonstrating the IDA's key role. ${ }^{2}$

On July 1, 2017, Bolivia, Sri Lanka, and Vietnam officially graduated from IDA. In one sense, IDA graduation is good news for a country, because it signals that significant economic growth has occurred. But graduation also means that, based on current World Bank rules, they have lost their access to concessional financing (loans and grants) from IDA. IDA graduation is typically followed by decreased access to concessional financing from other donors too.

The loss of access to concessional financing causes considerable challenges and risks, as growth is often accompanied by social dislocation, governance limitations and unequal distribution of economic gains. In theory, LMICs have enough domestic resources to address these challenges; in practice, however, vested interests and institutional constraints make it difficult to mobilize new revenues for public purposes. The World Bank recognizes the challenges that graduation causes countries and has opened up the discussion regarding ways to help countries transition. In fact, World Bank officials indicate there have already been important changes to graduation criteria, with internal assessments of a variety of country dynamics now informing graduation decisions. And, while the graduation from IDA to non-IDA formally takes place according to the World Bank annual cycle, removing access to IDA may take place more gradually. (See Box 1 and 2 for more details.)

The World Bank is not the only donor that has been questioning the appropriate way to help countries that transition through different phases of development by providing financing for development and/or providing non-financial support. In 2019, the Development Assistance Committee (DAC) of the Organization of Economic Co-operation and Development (OECD), a forum to discuss aid issues among traditional aid donors, is developing guidance for all donors on their approach to countries transitioning away from a largely ODA-based relationship.

The 2017 DAC High Level Meeting (HLM) Communiqué ${ }^{3}$ called for "analytical work to help identify where ODA is most needed (such as in least-developed countries, low-income countries, small island developing states, landlocked developing countries, and fragile and conflict-affected contexts) and where additional actions may be required" (para. 19). It also recognized "the need to ensure that development co-operation approaches and tools can effectively respond to the new complexity of sustainable development by providing appropriate support to countries as they transition through different phases of development." It called for review and reflection "on the 
evidence base that documents the consequences of different graduation processes on access to development finance from all sources, and [...] policy analysis on the different patterns of cooperation, including financing, channels, and objectives in countries in transition" (para. 20). In 2018, it carried out a study with the Cabo Verde government to assess the country's challenges as it graduates from LDC status to LMIC. ${ }^{4}$ This is parallel to an additional DAC mandate to promote "a future in which no country will depend on aid" (para. 22).

Similarly, the Administrator of the United States Agency for International Development (USAID), Mark Green, has stated that the objective of foreign assistance "should be ending its need to exist." 5 Green began an internal process to create a policy framework designed to support strategic transitions away from largely ODA-based relationships. As detailed in Box 6 (Annex III) of this report, setting appropriate criteria to determine transition readiness, with the intention of guiding investments towards these preparations, is one of the key work streams in the new policy.

Oxfam believes that the ultimate purpose of aid is to create a world where aid is no longer necessary. However, many developing countries rely on ODA and the bilateral relationships created with ODA to help support poverty reduction. When done transparently and effectively, aid can play a vital role in helping developing countries grow, fight poverty and inequality, promote gender equality, encourage good governance, and meet humanitarian needs. While aid is not sufficient on its own to tackle these problems, it is often necessary. The central role of aid in a post-2015, when the Sustainable Development Goals (SDGs) were agreed, world should be to support the citizenstate compact (illustrated in Figure 1).

\section{Figure 1: The citizen-state compact}

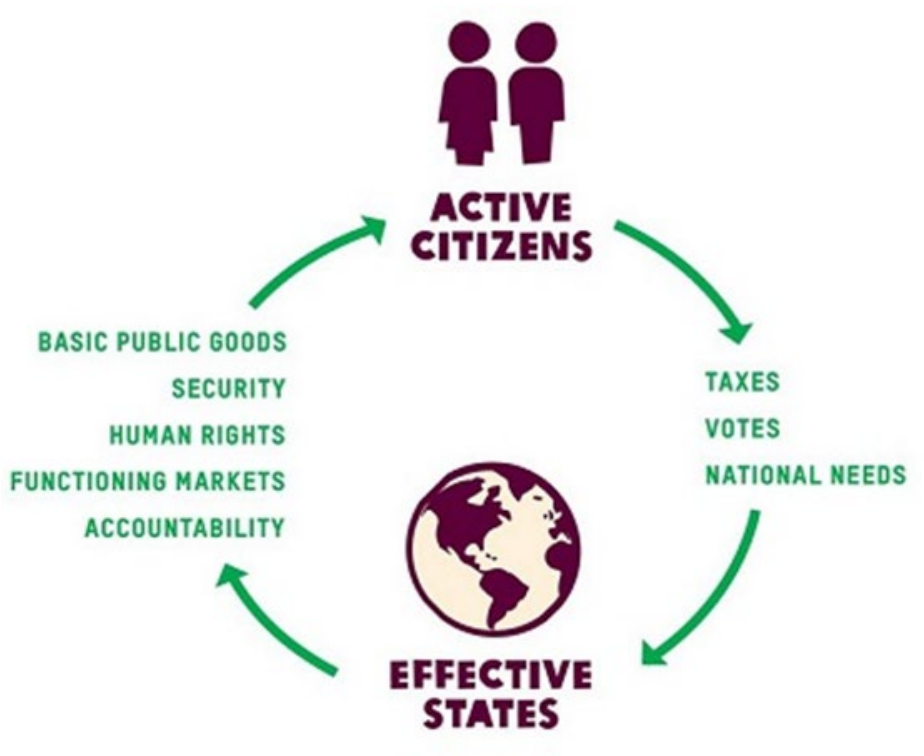

Source: Oxfam America (n.d.). Active Citizens and Accountable States. Available at: https://policy-practice.oxfamamerica.org/work/active-citizens-accountable-states/.

The citizen-state compact sits at the center of the relationship between citizens and government institutions in a country, and is necessary to drive continued progress in development. Aid remains as relevant as ever for the world's poorest countries and communities. Ultimately, accountability for the achievement of the SDGs lies with governments. Governments have the primary responsibility for making the investments that are necessary for all their citizens to achieve the SDGs and "leave no one behind." 6 
There are risks associated with withdrawing ODA too early. Distribution of ODA is determined by key indicators that are set up and defined in mostly northern-dominated global institutions. These indicators lack important nuances. For example, because of high and growing levels of inequality, per capita income is an inadequate indicator of whether a country continues to need concessional financing. With the majority of the world's poor people living in middle-income countries (MICs), there is an urgent need to rethink the criteria for transition away from ODA, particularly the criteria for determining when a country is ready to graduate from IDA. Criteria should focus more on the ability of the country to reach the SDGs and the need to "leave no one behind."

Oxfam is concerned about the risks associated with graduating too soon, and especially that graduating countries will face different finance terms from other lenders as well - not just the World Bank - and could therefore find themselves heavily indebted very quickly. This could significantly undermine their ability to finance the SDGs. In response, donors are promoting various adjustments, including boosting domestic revenue mobilization (DRM) for public development projects as well as mobilizing the private sector for development. In fact, Vietnam is one of the World Bank's pilots for its new Maximizing Finance for Development (MFD) agenda, which focuses on mobilizing the private sector and is described in more detail in Annex III.

Similarly, the Government of Vietnam (GoV) (2015) stated: "Reductions in ODA create difficulties in the government's financing of several social and economic activities, particularly in the provision of healthcare for the disadvantaged and in poverty reduction. The impact mostly lies in the reduced flexibility to carry out new policies and reforms. Therefore, one of the priorities for the coming years is to use these resources in a more strategic and effective manner to maximize the expected outcomes. The Government of Vietnam is also keen to increase the share of financing from other sources, including the private sector (foreign as well as domestic) through public private partnerships." 7

\subsection{COUNTRY FOCUS, METHODOLOGY AND MAIN RESEARCH QUESTIONS}

This report focuses on Vietnam, though it also refers a few times to fellow graduates Bolivia and Sri Lanka. Among the three countries that graduated from IDA on July 1, 2017, at the end of the latest three-year replenishment period, "IDA18," Vietnam is arguably the best prepared in terms of its recent growth and poverty reduction record. Yet, even so, Vietnam faces a series of development challenges that may be aggravated by reduced access to ODA. Exploring these challenges for a well-prepared country sheds light on the scope of the challenges for other graduating countries that are in less-favorable circumstances.

This report combines longitudinal quantitative and qualitative research methods through the review of secondary literature, the use of various databases, and in-depth interviews. Quantitative analysis in this report relied mostly on OECD aid statistics, the World Bank's World Development Indicators (WDI) and International Debt Statistics (IDS), and data provided in various other reports, including from the GoV. Qualitative analysis included use of desk research and in-depth interviews with 18 selected key informants (from the GoV, multilateral and bilateral donors, and Vietnamese research centers), which took place in May 2018.

Quantitative data have been collected and examined for consistency across different sources. The data have then been analyzed using descriptive analyses, especially figures, that shed light on the evolution of various aid and debt indicators. The data were then summarized verbally and examined for implications based on standard economic theory. Qualitative data were analyzed through 
content analysis and then combined and checked for consistency with qualitative assessments in the literature.

Finally, the debt sustainability analysis in Section 3.2 used a debt projection module developed in 2002 by Gunter, Lopez, Ramadas, and Wodon at the World Bank. It was used widely during the subsequent decade, including by researchers outside the World Bank. The module uses standard calculations for the projections (like any debt projection module does) based on the assumptions stated in the report. Further details on these assumptions are available upon request.

The four research questions for the research behind this discussion paper were:

1. What is the development finance portfolio for Vietnam now and in the future?

2. What may be the effect of these trends on Vietnam's ability to fight poverty, inequality, and gender inequality now and in the future?

3. What are the implications of IDA graduation on other sources of concessional development finance?

4. What can bilateral donors, multilateral donors, and the GoV do to ensure continued resources are effectively invested in fighting inequality, poverty, and gender inequality?

The remainder of this report is structured as follows: The next section (Section 2) examines the impact the changing development finance portfolio has on Vietnam by analyzing the relevance of ODA for Vietnam's ambitious development goals. It includes a review of the relevance of ODA by sector, and how the government has responded to the decline in ODA. Section 3 analyzes the impact the changing development finance portfolio has on Vietnam's public debt sustainability. Section 4 addresses when the right time is for IDA and other donors to withdraw aid. The last section provides recommendations.

There are four annexes, which are provided to give a better understanding of the broader context and the key messages of this report. Annex I provides a snapshot of Vietnam's recent development in terms of economic growth, human development, poverty reduction, economic inequality, gender inequality, and social mobility. Annex II provides recent trends in Vietnam's private external development finance. Annex III details prospects for external development finance, while Annex IV explores Vietnam's domestic development finance portfolio. 


\section{THE CHANGING RELEVANCE OF ODA IN VIETNAM}

This section examines the impact of changes in Vietnam's overall portfolio of ODA by first analyzing the relevance of ODA for Vietnam's development goals. It then provides some sectoral analysis, reviewing the relevance of ODA by sector in order to get a better idea of which sectors may suffer the most from the recent and further decline in ODA. It concludes by discussing the government's plans for receiving ODA in the future.

\subsection{VIETNAM'S DEVELOPMENT AND FUNDING LANDSCAPE}

Vietnam has experienced rapid economic growth in the last 30 years of Đổi Mới (Renewal) reforms (averaging 6.4 percent from 1985-2016), characterized by rising average incomes and a steady and significant fall in the number of people who are living in poverty. Indeed, from 1992 to 2016 more than 30 million people escaped extreme poverty in Vietnam, defined as living below $\$ 1.90$ a day purchasing power party (PPP, adjusted 2011). ${ }^{8}$ Vietnam's Human Development Index (HDI) increased from 0.48 in 1990 to 0.68 in 2015. In terms of current US dollars, GDP per capita increased from $\$ 95$ in 1990 to $\$ 2,171$ in 2016. Vietnam attained LMIC status in 2009 and achieved all of the Millennium Development Goals (MDGs), with the exception of environmental protection.

Vietnam performed well on both human development and economic growth in the early and midĐổi Mới years, but Vietnam's strong performance has waned in recent years, especially after the 2008 global financial crisis. Disparities between regions, provinces, and population groups have not been closed. While past growth has brought significant social transformation, it has also brought social risks and dislocations. Those still in poverty are harder to reach, particularly within ethnic minority communities. ${ }^{9}$

As of 2016, 1.9 million Vietnamese lived below $\$ 1.90$ a day, 8.1 million lived below $\$ 3.20$ a day, 9.3 million lived below the national poverty line (which is equivalent to 2011 PPP $\$ 3.34$ a day), and 25.5 million lived below $\$ 5.50$ a day. From 2014 to 2016, national statistics show poverty declining nationwide for both ethnic minorities and the majority of the population. The poverty gap, which measures how far consumption of the poor is below the poverty line, has also steadily declined, indicating that poverty is becoming less severe among those still living in poverty. However, about 30 percent of Vietnam's population can still be classified as economically insecure (which is defined as having a daily per capita consumption of less than a 2011 PPP of $\$ 5.50$ ). While welfare has improved across the board, inequalities between groups are not closing fast enough. Close to 45 percent of ethnic minorities still live in poverty. Thus, ethnic minorities who make up only 15 percent of the country's population, constituted 73 percent of the poor in $2016 .{ }^{10}$

While the impact of this rapid growth on economic inequality in Vietnam has been more modest than in most other countries, as documented in Oxfam's (2017) Vietnam inequality report, economic inequality has been increasing. The challenge of eliminating poverty and achieving economic security (which is internationally defined as having a daily per capita consumption of at least a 2011 PPP of $\$ 5.50$ ) is significant. Despite the rapid poverty reduction Vietnam achieved between 2010 and 2016 (the average reduction in the $\$ 5.50$ poverty line was 21.3 percent for every two years 
between 2010 and 2016), it will take until at least 2031 for the percentage of people living below $\$ 5.50$ (2011 PPP) to fall below 5 percent. ${ }^{11}$

The World Bank (2018) concludes that Vietnam is far from being done with the job of eliminating poverty and that there are various new challenges that need to be addressed. The World Bank and GoV have also raised concerns about Vietnam's future economic trajectory, suggesting that that the country needs to address some of the underlying bottlenecks if it wants to achieve more inclusive growth in the medium to long term. The GoV identifies these bottlenecks as including access to education, employment, and vocational training; lack of technological innovation; and the need for a more effective social protection system. ${ }^{12}$

Finally, given that Vietnam is one of the countries most vulnerable to climate change, Vietnam's future growth rate is heavily dependent on climate and other environmental factors. Climate change-related disasters, such as annual typhoons and ongoing salinization of the Mekong Delta, tend to reduce growth and could erode decades of progress in poverty reduction. While addressing the impacts of climate change, the GoV also faces environmental risks resulting from its own pursuit of high growth rates as a goal rather than a means of development. ${ }^{13}$ These social and environmental risks are increasing in spite of-or in some cases directly because of-continued GDP growth. A decline in access to concessional financing and donor-supported technical assistance following IDA graduation would remove one important avenue to address these risks.

\subsection{ODA IN VIETNAM'S DEVELOPMENT FINANCE PORTFOLIO}

Excluding some temporary declines, total net ODA to Vietnam (including both development grants and concessional loans) increased steadily each year from 1990 to 2014 (reaching a maximum of $\$ 4.22$ billion), but then declined relatively sharply to $\$ 2.89$ billion in 2016 (Figure 2). Meanwhile, ODA as a percentage of Vietnam's GDP has declined overall since the 1990s. 
Figure 2: Total net ODA to Vietnam, 1990-2016

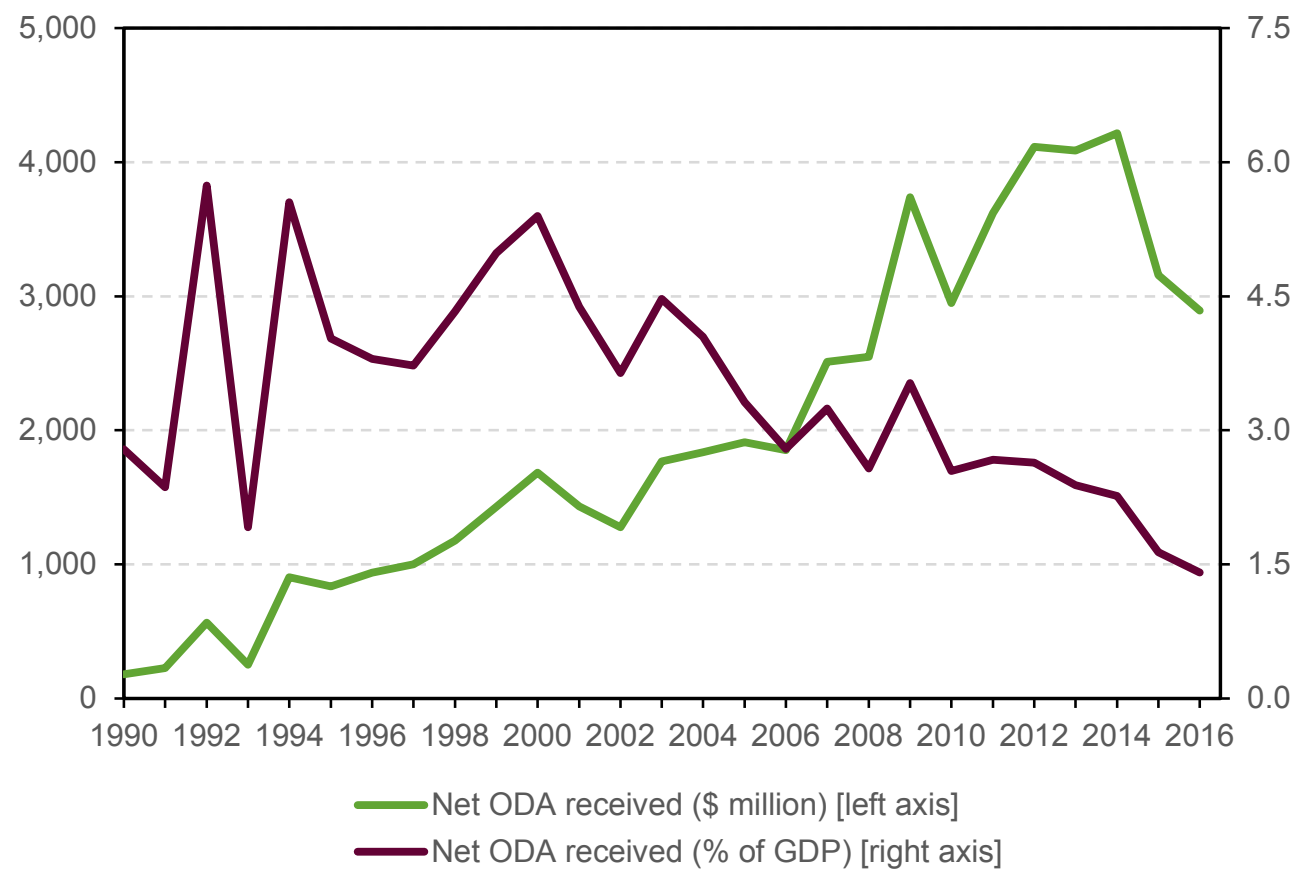

Source: Based on World Bank (2018), WDI/IDS database. Available at https://datacatalog.worldbank.org/dataset/world-development-indicators:

Looking at more recent years and some projections (2012-2019), the left chart of Figure 3 shows that actual net ODA to Vietnam averaged $\$ 4.14$ billion per year from 2012 to 2014, after which it decreased by slightly more than one quarter in only two years to $\$ 2.89$ billion in 2016 . While the longer-term trend is estimated to be downward, based on OECD data on country programmable aid (CPA) for 2017-2019, net ODA may have increased a bit in nominal terms for 2017, after which it is estimated to have declined. However, as the right chart of Figure 3 shows, actual net ODA expressed as a percentage of GDP shows a clearly declining trend since 2012 (despite the marginal increase from 2016 to 2017). Not only has the share of net ODA to GDP been declining, it is also small. In 2012, the net ODA-to-GDP ratio was 2.64 percent; in 2016 it was 1.41 percent, and for 2019 it is estimated to be 1.35 percent. 
Figure 3: Actual and projected net ODA receipts, 2012-2019
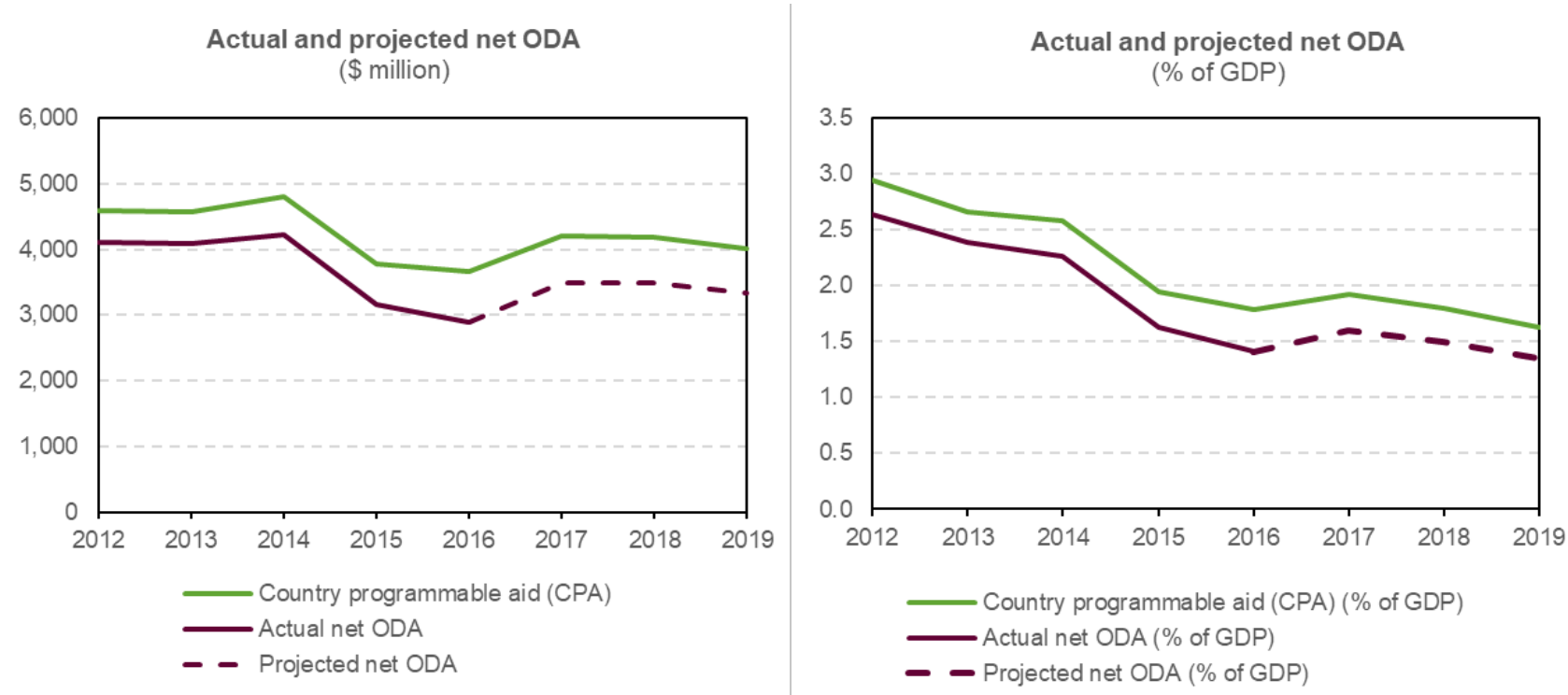

Source: Left chart: CPA is based on OECD (2018), CPA indicator and OECD Table 25e. Actual net ODA figures are based on World Bank (2018), WDI/IDS database; projected net ODA figures are estimated based on the average CPA-to-ODA ratio from 2014-2016. Right chart: Calculated by author based on left chart and using an annual GDP growth rate of 6.3 percent for 2017-2019.

While the net ODA-to-GDP ratio is indeed small (mainly because GDP has increased a lot), the impact of ODA goes beyond its size. According to the GoV, "in spite of accounting for only nearly 3 percent of GDP, the ODA and concessional loans from foreign donors in [the] 2011-2015 period have supported Vietnam a lot in socio-economic infrastructural development and reduction of poverty in a sustainable way." ${ }^{4}$ Some specific examples of contributions of ODA to education, health, water/sanitation and gender equality are presented in the following section.

To better understand the role of ODA, it is useful to compare ODA to (a) government expenses, (b) gross capital formation, and (c) total investment capital (TIC). ${ }^{15}$ This is shown in Figure 4. While the long-term trends are still downward, the ratios are far higher, especially for the ODA-to-TIC ratio. The ODA-to-TIC ratio was 42.7 percent in 2011, after which it increased to 57.9 percent in 2014 , before falling back to 41.3 in 2015 . The net ODA-to-government expense ratio declined more or less continuously from 14.5 percent in 2011 to 6.38 percent in 2016, while the net ODA-to-gross capital formation ratio declined from 9.0 percent in 2011 to 5.3 percent in 2016. 
Figure 4: ODA relative to government expenses, gross capital formation, and TIC

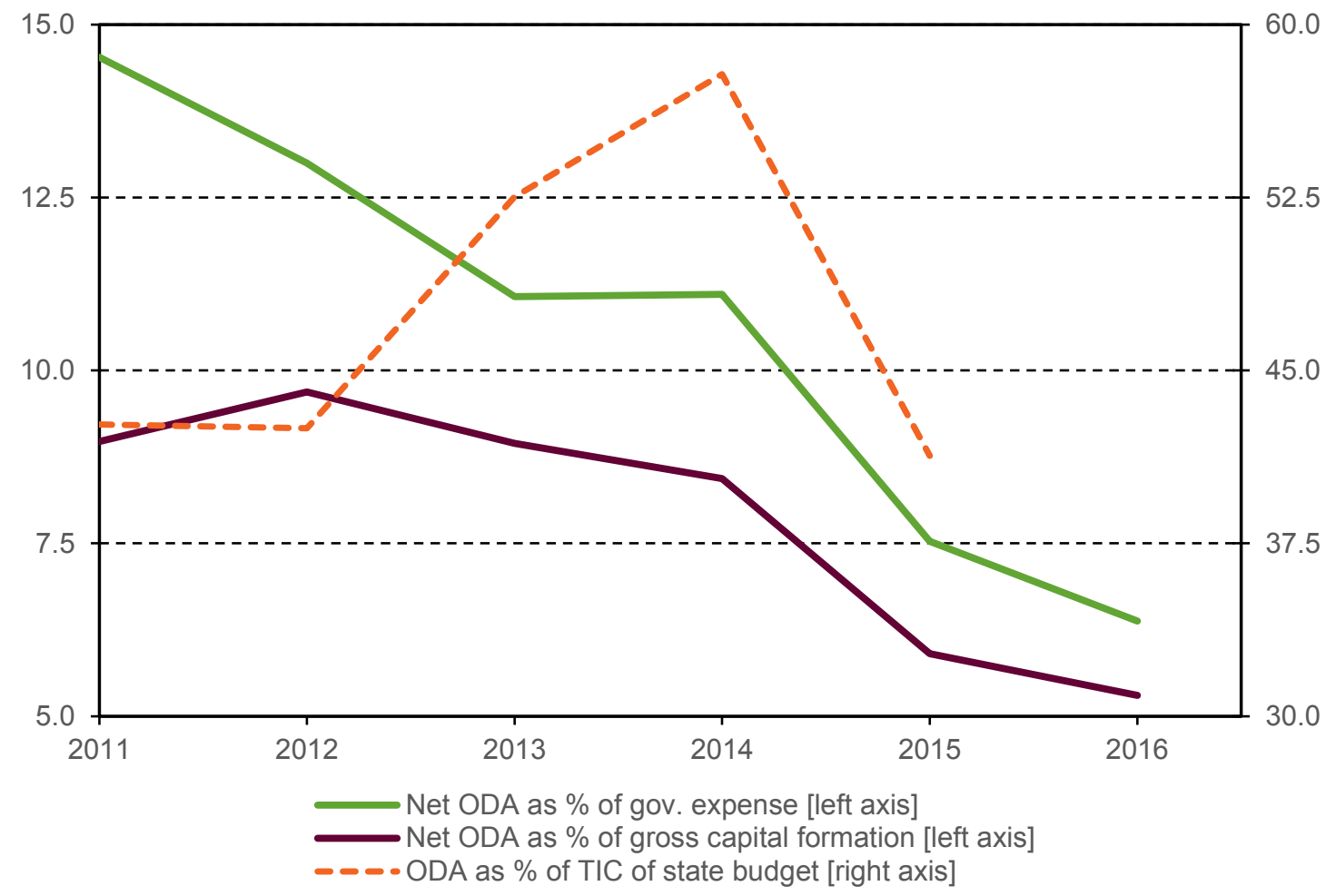

Source: TIC based on GoV (2016), Decision 251, Table 3; otherwise World Bank (2018), WDI/IDS database.

During the last two decades, some $\$ 4.3$ billion of aid has been provided to Vietnam via more than 1,000 international nongovernmental organizations (INGOs), of which the 500 most active have supported over 3,000 programs and projects focusing on gender, health, education, ethnic minority poverty reduction, and environmental protection. ${ }^{16}$ From 2013-2017, the average annual ODA disbursed via INGOs amounted to $\$ 297.4$ million, which is 8.3 percent of net ODA Vietnam received during these years. ${ }^{17}$ Some donors, notably Irish Aid and USAID, began to channel ODA funds to domestic Vietnamese NGOs over the same period. In addition, many INGOs work directly with Vietnamese civil society partners, meaning that a substantial part of ODA to INGOs has supported the development of domestic organizations.

If future reductions in ODA affect international and domestic NGOs, these investments are not likely to be taken over by domestic donors, the private sector, or government agencies. Some within the government believe that the reduced availability of ODA will require a reduction in, or end to, ODA channeled through non-state recipients in favor of centralization, with a focus on funding largescale, nationally important infrastructure projects and projects which have potential to generate revenues.information ${ }^{18}$

Figure 5 shows that by 2016, Vietnam's donors provided nearly all (90 percent) of their assistance via project-type interventions. General budget support, which amounted to 18.2 percent of total assistance in 2009, was less than half a percent in 2016, while the share of sector budget support was reduced from 14.6 percent in 2009 to 3.6 percent in 2016. 
Figure 5: ODA by type of provision, 2008-2016
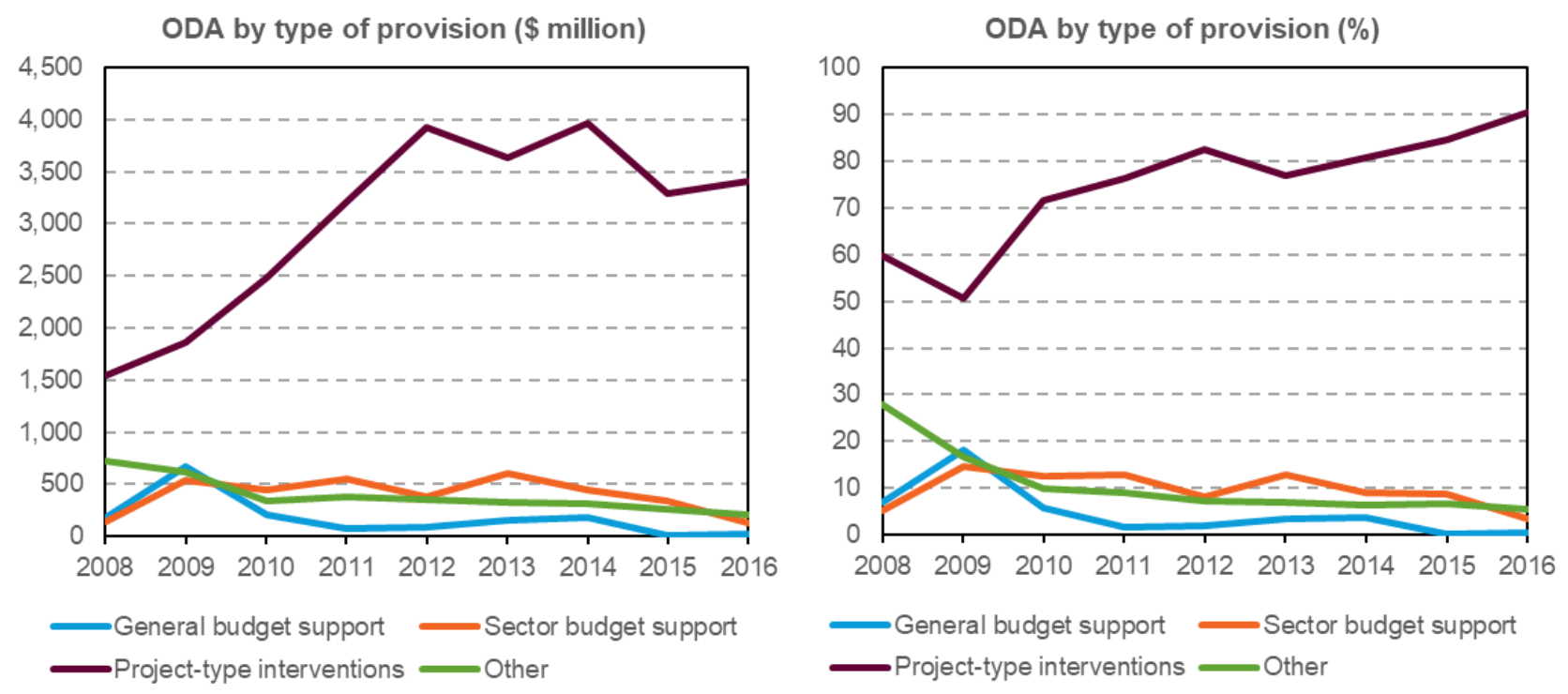

Source: Created by author based on OECD DAC CRS database.

\subsection{MULTILATERAL AND BILATERAL ODA DONORS TO VIETNAM}

Governments can raise external funds to finance development from:

1. International organizations, mostly multilateral development banks (MDBs) like the World Bank and the Asian Development Bank (ADB);

2. Other governments, mostly advanced countries constituting the OECD, though some new donors like China have emerged more recently; and

3. Foreign commercial banks (via loans or sovereign bonds).

Figure 6 shows the flow of concessional funds to Vietnam (in terms of gross disbursements) from IDA from 1990 to 2018 (though the data for 2017 and 2018 is based on commitments as data on actual disbursements was not available at the time of research). Typical IDA loans are highly concessional as they come with a long maturity and zero interest rate, though there is a fee of 0.75 percent on outstanding and disbursed loans equivalent to an interest rate.

Figure 6 shows that IDA's disbursements have been volatile. Concessional ODA from IDA started to decrease drastically following its all-time high of $\$ 1.38$ billion in 2014, decreasing to $\$ 915$ million in $2015, \$ 756$ million in 2016, $\$ 313$ million in 2017 , and $\$ 0$ in 2018 . Given that Vietnam graduated from IDA on July 1, 2017, the last time the GoV received concessional funds from IDA was in the first half of 2017. IDA continues to provide loans to the Vietnam on a transitional basis, but these loans are provided at non-concessional International Bank for Reconstruction and Development (IBRD) terms. 
Figure 6: Disbursements of ODA from IDA (current \$ million), 1990-2018

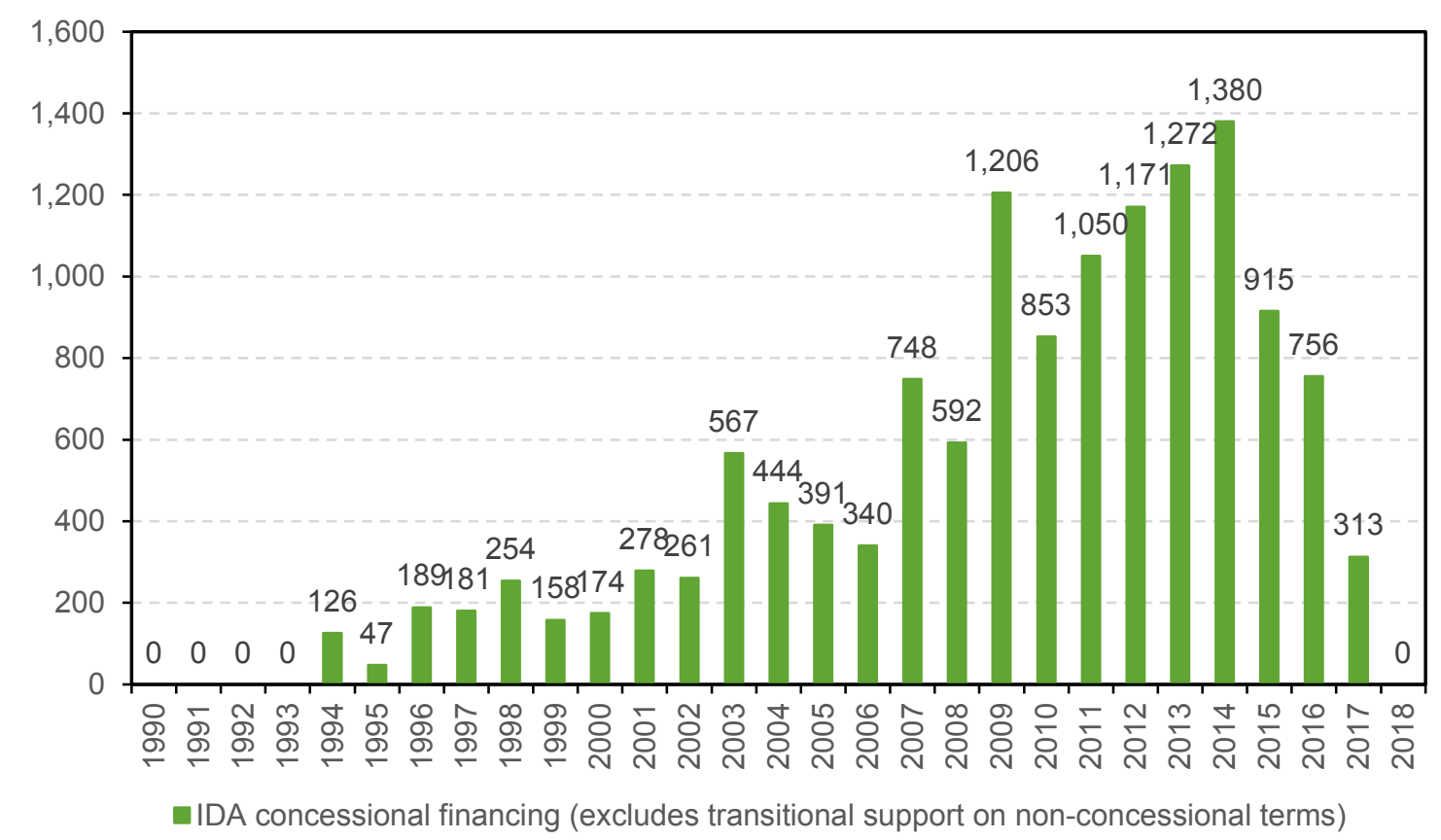

Source: World Bank (2018), WDI/IDS database [data for 1990-2016]; IDA (2017), IDA Country Allocations for FY17, Table 1; and World Bank Group (2017) Vietnam - Country Partnership Framework for the Period FY18FY22.

As Figure 7 shows, some of this decline in ODA from IDA has been replaced by disbursements of non-concessional loans from IDA and IBRD. However, keeping in mind that the data for 2017 and 2018 are based on commitments (and that commitments are typically higher than actual disbursements), it may well be the case that the sum of IDA and IBRD disbursements have been declining since 2014. 
Figure 7: Concessional and non-concessional borrowing from the World Bank (\$ million), 1990-2018

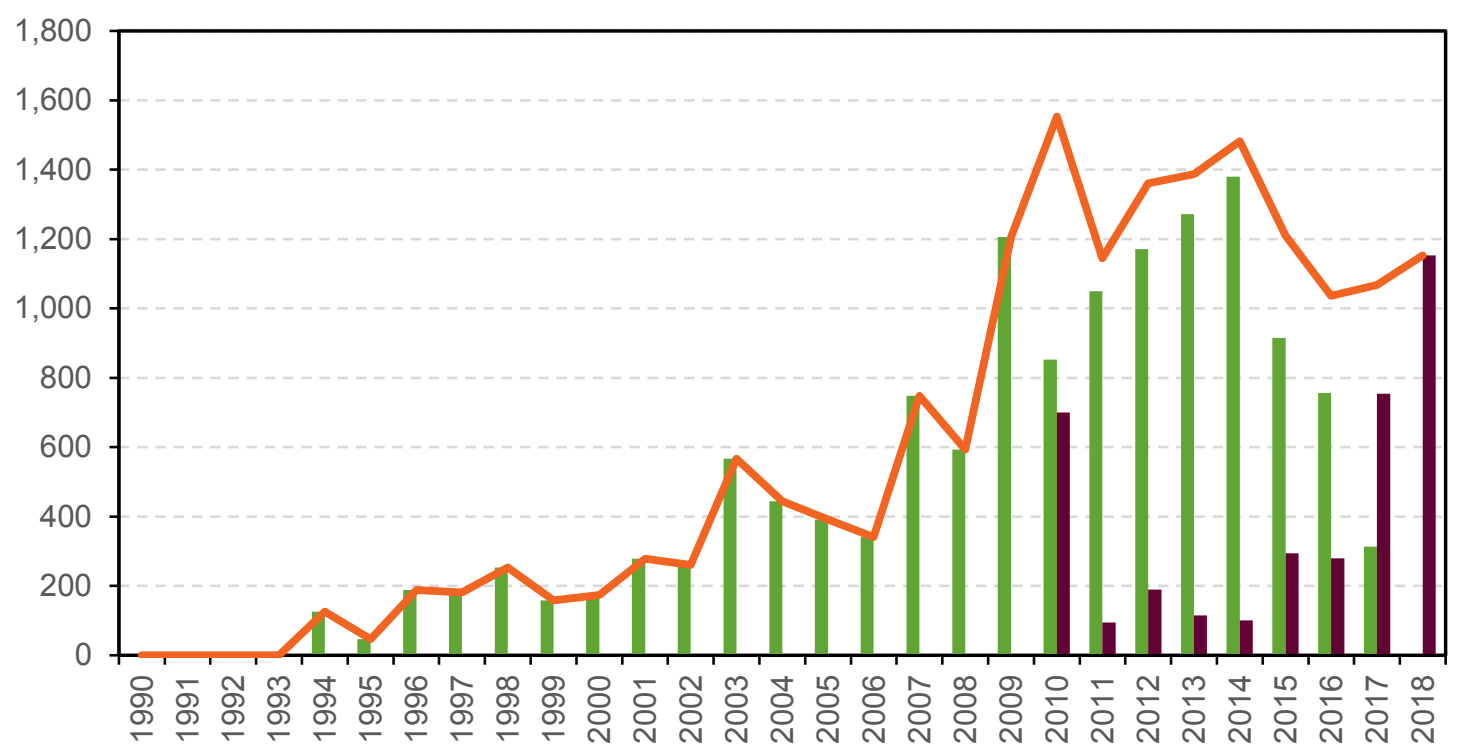

IDA concessional financing (excludes transitional support on non-concessional terms)

IBRD (non-concessional financing) and IDA transitional support on non-concessional terms

Total of IDA and IBRD

Source: World Bank (2018), WDI/IDS database [1990-2016]; IDA (2017), IDA Country Allocations for FY17, Table 1; IBRD Financial Statements, FY17; and World Bank Group (2017) Vietnam - Country Partnership Framework for the Period FY18-FY22 (2017 and 2018 calendar year based on halves of two fiscal years).

The other main multilateral donor (in terms of financial flows) to Vietnam is the ADB, which has provided substantial concessional loans to Vietnam for many decades and also started to provide substantial non-concessional loans to Vietnam since 2009. The two top lines of the left chart of Figure 8 show, respectively, the gross disbursement of all multilateral loans and the gross disbursement of all multilateral concessional loans. As reference points, the two lines below show the gross disbursements from IDA and IBRD. Most of the difference between total multilateral concessional disbursements and IDA's disbursements is due to the ADB's disbursements of concessional loans (so-called Asian Development Fund (ADF) loans or credits, which typically come with a long maturity and a 2 percent interest rate/fee). 
Figure 8: Gross and net disbursements on multilateral loans, 1990-2016
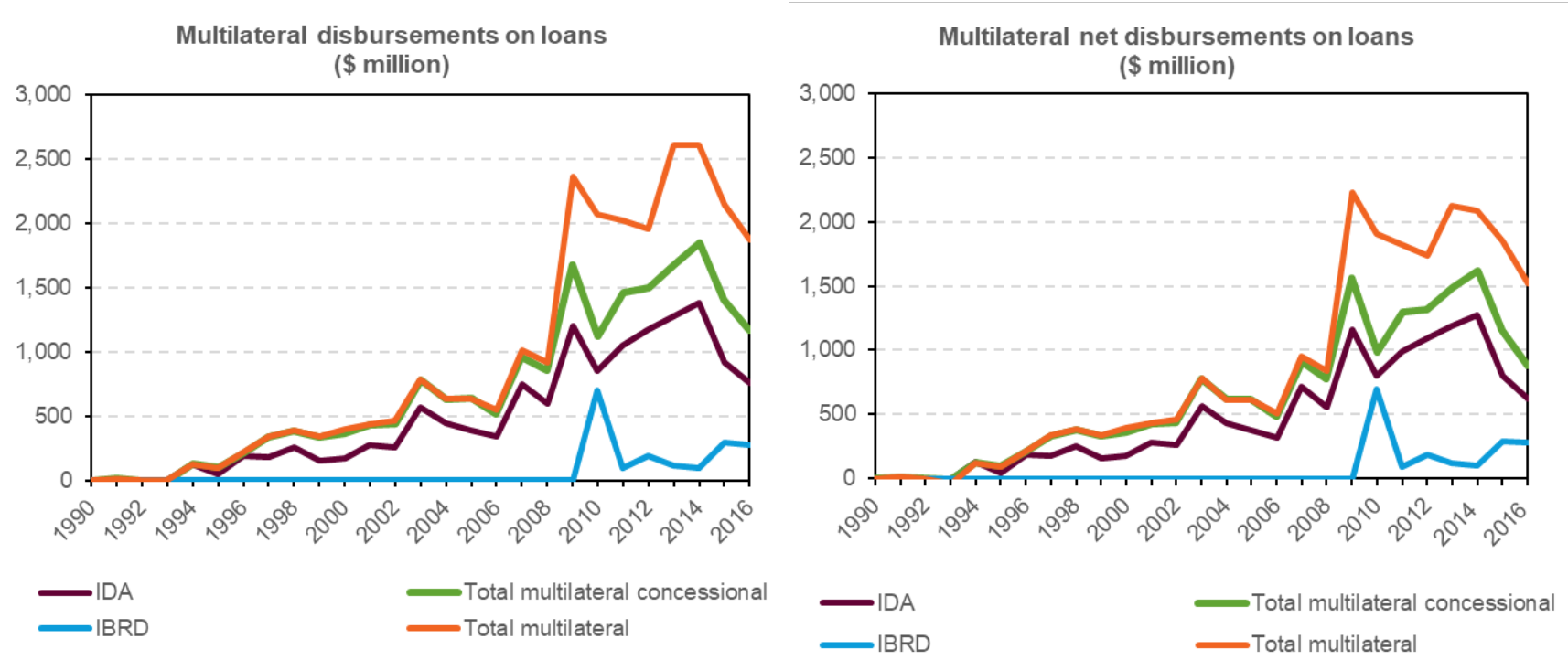

Source: Based on World Bank (2018), WDI/IDS database.

Though not a multilateral development bank, the European Union (EU) also has significant ongoing aid programs in Vietnam worth about $\$ 480$ million under its Multi-annual Indicative Program 20142020. ${ }^{19}$ Most of this aid is in grant form, hence it is not included in Figure 8. As things stand, the EU is not phasing out of Vietnam and it is expected that the EU will commit new funds beyond 2020. The two biggest EU programs for the period 2014-2020 are rural electrification (with funding commitments of about $\$ 415$ million), and a Governance and Rule of Law project (with commitments of about $\$ 60$ million). ${ }^{20}$

The top line of Figure 9 details the total bilateral net aid flows from all DAC donors, and shows an overall increasing trend from 1990 to 2012, and a clear decline since. Given the large share of Japan in total bilateral aid flows, Figure 9 also shows Japan's net aid flows, and highlights that flows from Japan largely determine the trends of the total bilateral aid flows. Japan's share in total bilateral aid reached an all-time high of 72.5 percent of the total bilateral aid flows in 2000 , though it still averaged 55 percent from 2010 to 2016. During that period, Japan's bilateral aid was more than the sum of all other bilateral donors together. One important difference of Japanese bilateral aid to that of aid provided by most other DAC donors is that Japan (also South Korea) provides most of its aid via concessional loans, while most of the other DAC donors provide their aid mostly via grants. 
Figure 9: Bilateral net aid flows from Japan and all DAC donors (\$ million), 1990-2016

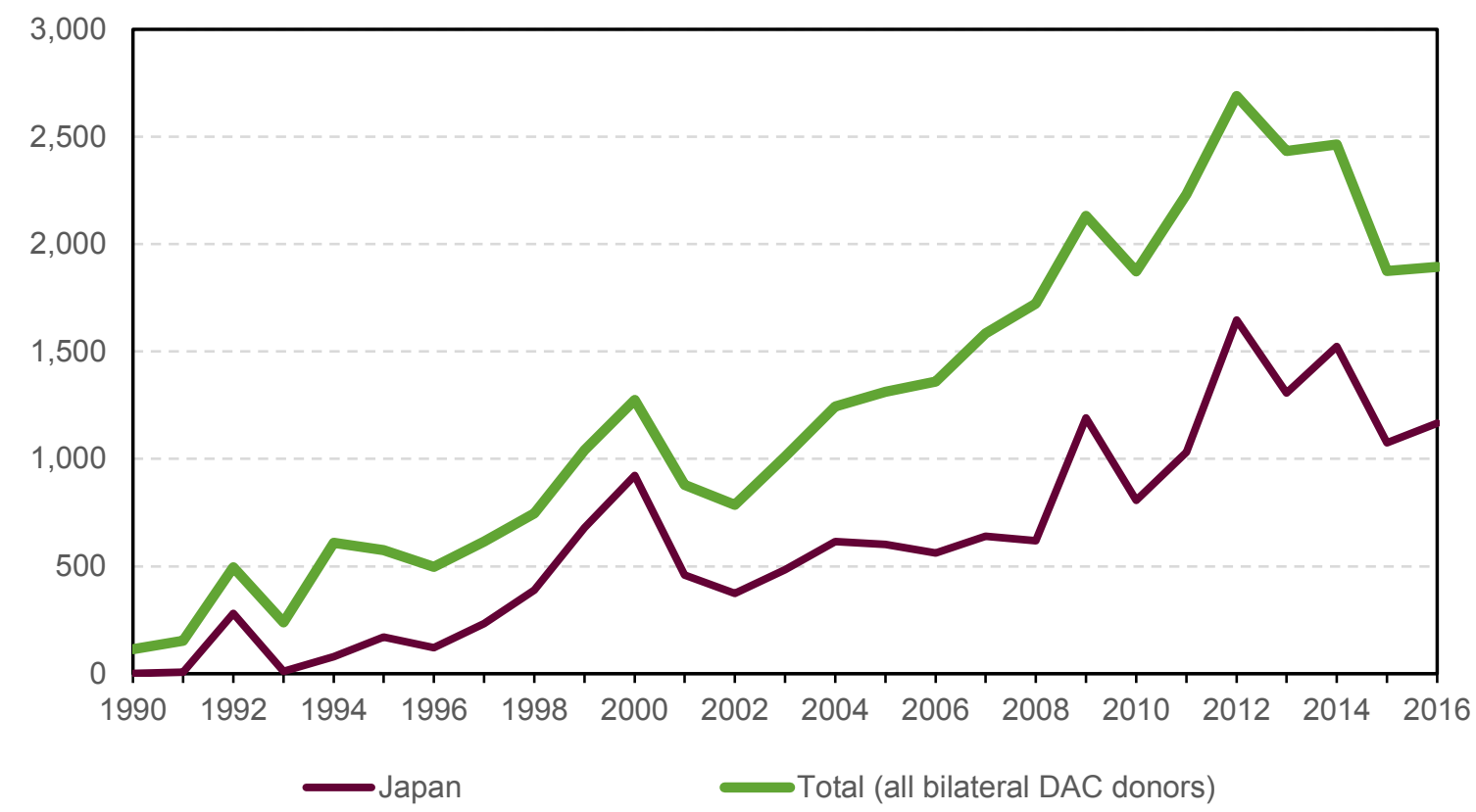

Source: Based on World Bank (2018), WDI/IDS database.

Figure 10 shows the bilateral net aid flows of the seven largest bilateral donors to Vietnam, excluding Japan. For most of the years, France was Vietnam's second largest bilateral donor. However, since 2012, the South Korea has replaced France as Vietnam's second largest bilateral DAC donor. For several bilateral donors, net aid flows to Vietnam are clearly declining. Denmark's net aid peaked in 2007 (when it was the fifth largest DAC aid donor), the UK's net aid peaked in 2008 (when it was the third largest DAC aid donor), France's net aid peaked in 2010 (when it was the second largest DAC aid donor), Japan's net aid peaked in 2012, and Australia's and South Korea's net aid peaked in 2013. Among the eight largest bilateral DAC donors to Vietnam, only Germany and the US show an increasing trend. Some of Vietnam's traditional bilateral development partners, particularly European donors, have already decided to transition away from bilateral assistance, though they continue to provide assistance through multilateral channels or via global or regional programs. Indeed, the Netherlands stopped its bilateral support in 2012, Sweden in 2013, Denmark in 2015, the UK in 2016 and Finland in 2017/18. ${ }^{21}$ 
Figure 10: Bilateral net aid flows from major DAC donors (\$ million), excluding Japan, 19902016

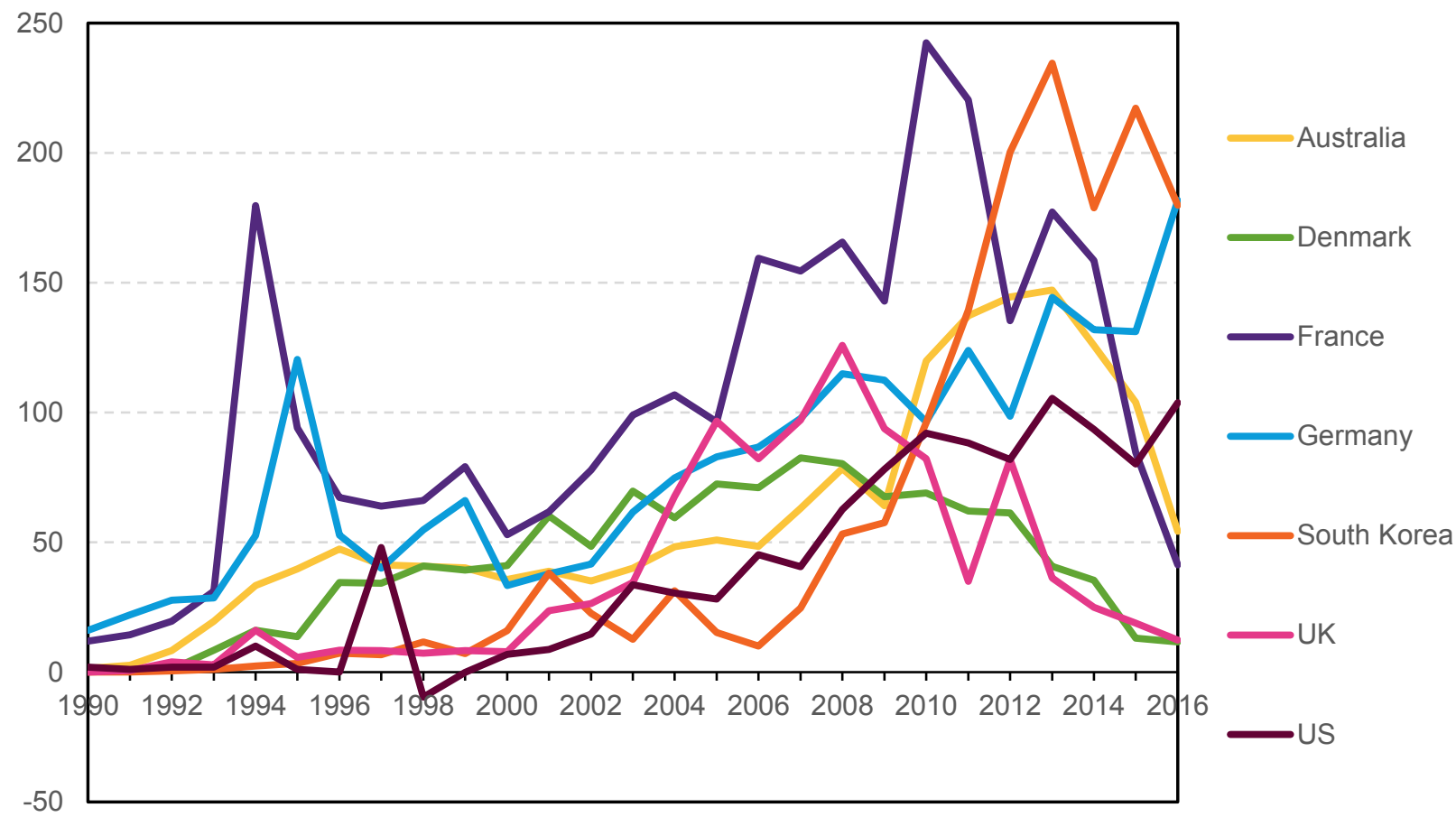

Source: Based on World Bank (2018), WDI/IDS database.

There is no data available on concessional or non-concessional loans from China to Vietnam, neither within the World Bank's International Debt Statistics (IDS) database nor in the OECD online database. However, based on a 2017 OECD report, ${ }^{22}$ China's net ODA in 2015 amounted to $\$ 3.4$ billion. While it is unknown if any of this Chinese ODA has been provided to Vietnam, it is known that China provides commercial loans to Vietnam that do not qualify as ODA. However, like for the DAC donors, there are no detailed data available on other official flows (OOF) from bilateral donors (i.e., non-concessional). 


\subsection{RELEVANCE OF ODA BY SECTOR}

\section{Overall issues with allocation}

The allocation of ODA to Vietnam varies considerably across sectors. The 2011-2015 average annual allocation of ODA in Vietnam is shown in Figure 11 and is based on data from the Ministry of Planning and Investment, and then updated with OECD data for 2016 in Figure 12.

Figure 11: Average annual ODA by sector (\$ million and percent), based on 2011-2015
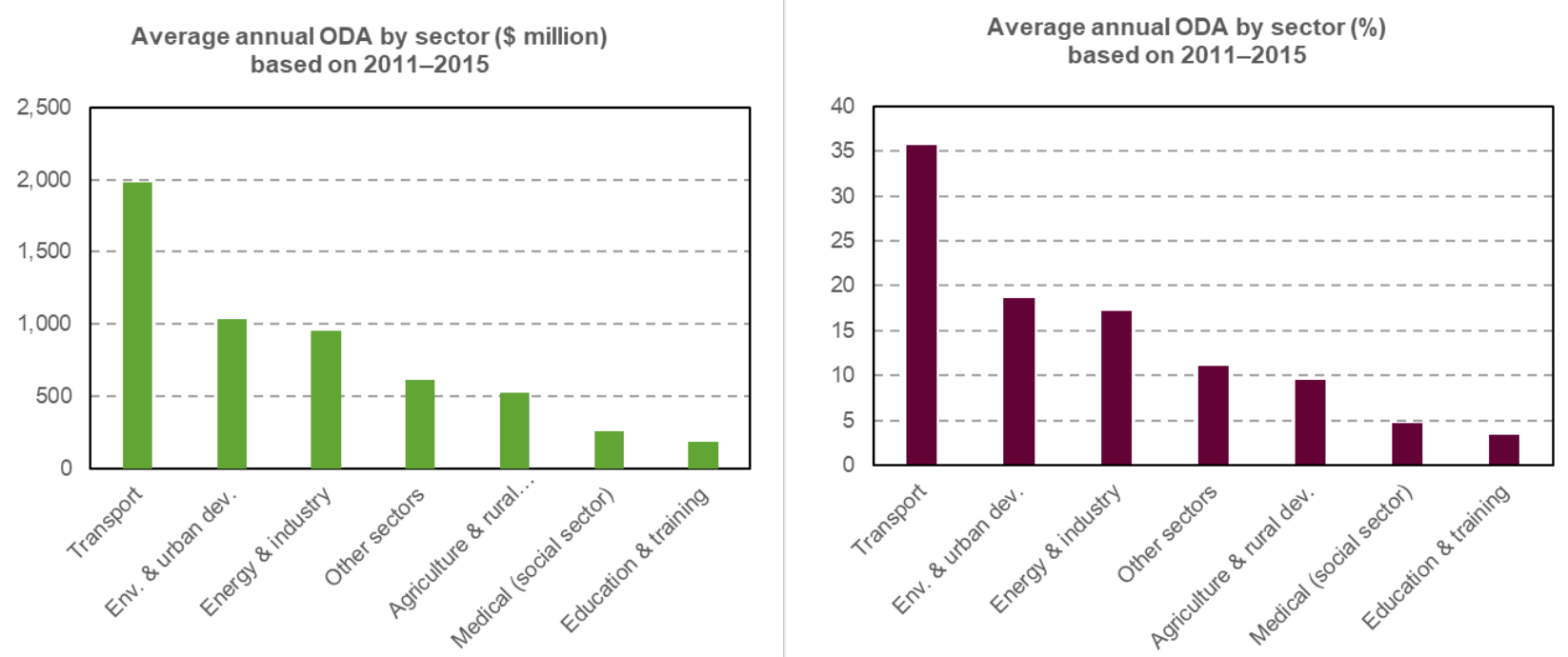

Source: Decision 251, Table 1, referring to data by the Ministry of Planning and Investment.

During 2011-2015, the largest proportion of ODA to Vietnam (35.68 percent) went to the transport sector, 18.65 percent was provided for environmental and urban development projects (including water supply, drainage, and response to climate change), and 17.14 percent was provided for energy and industry projects. On the other hand, agriculture and rural development, medical (i.e., health), and education and training received, respectively, only 9.47 percent, 4.65 percent, and 3.35 percent of the total ODA.

Though the OECD information for 2016 provided in Figure 12 is using a different sector classification, the data does not seem to indicate that there has been a major reallocation towards social sectors. To the contrary, given that 68 percent of all ODA in 2016 has been allocated to economic sectors (including transportation, energy, and industry), which added up to 53 percent during 2011-2015, the recent reallocation of ODA seems to have been away from social sectors. 
Figure 12: ODA by sector committed for 2016 (\$ million and percent)
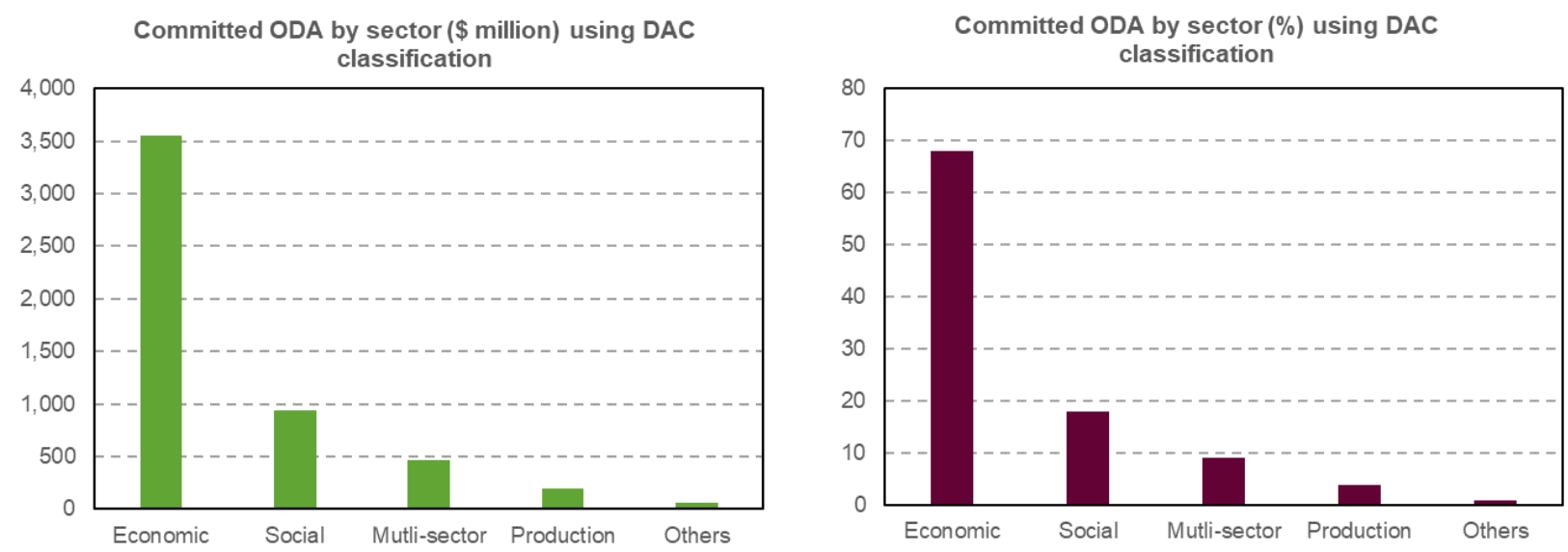

Source: Based on data provided in OECD DAC (2018), Development Aid at a Glance, Table 1.3.6.

As Table 1 shows, there are large differences in how ODA is allocated to sectors across the three countries that graduated from IDA in 2017, despite all countries having similar GDP per capita. In Vietnam, the lion's share (68 percent) of all ODA is allocated to economic sectors. On the other hand, in Bolivia and Sri Lanka, only 8.7 percent and 37.4 percent are allocated to economic sectors. In Vietnam, the second largest share (18 percent) is allocated to social sectors (mostly education, health, and water and sanitation), while social sectors get 30.1 percent and 29.0 percent, respectively in Bolivia and Sri Lanka. The reason for these differences appears to be government priorities: In Vietnam, Decision 251/QD-TTg explicitly prioritizes ODA to economic sectors (see section 2.5 below), with social sector development in a subordinate position.

Table 1: ODA by sector in Vietnam, Bolivia, and Sri Lanka (based on 2016 commitments)

\begin{tabular}{|l|l|l|l|l|l|l|l|l|l|}
\hline & Social & Economic & $\begin{array}{l}\text { Prod- } \\
\text { uction }\end{array}$ & $\begin{array}{l}\text { Multi- } \\
\text { sector }\end{array}$ & $\begin{array}{l}\text { Gen. prog. } \\
\text { aid }\end{array}$ & $\begin{array}{l}\text { Humani- } \\
\text { tarian }\end{array}$ & Others & Total \\
\hline & \multicolumn{5}{|l|}{ Commitments (\$ million) } \\
\hline Vietnam & 943 & 3,555 & 197 & 470 & 5 & 52 & 7 & $\mathbf{5 , 2 2 9}$ \\
\hline Bolivia & 261 & 75 & 104 & 312 & 9 & 104 & 3 & $\mathbf{8 6 7}$ \\
\hline $\begin{array}{l}\text { Sri } \\
\text { Lanka }\end{array}$ & 553 & 715 & 256 & 234 & 95 & 55 & 1 & $\mathbf{1 , 9 1 0}$ \\
\hline & By sector for each country (\%) & & & & & & \\
\hline Vietnam & 18.0 & 68.0 & 3.8 & 9.0 & 0.1 & 1.0 & 0.1 & $\mathbf{1 0 0 . 0}$ \\
\hline Bolivia & 30.1 & 8.7 & 12.0 & 36.0 & 1.0 & 12.0 & 0.3 & $\mathbf{1 0 0 . 0}$ \\
\hline $\begin{array}{l}\text { Sri } \\
\text { Lanka }\end{array}$ & 29.0 & 37.4 & 13.4 & 12.3 & 5.0 & 2.9 & 0.1 & $\mathbf{1 0 0 . 0}$ \\
\hline
\end{tabular}

Source: Created by author based on information provided in OECD DAC (2018), Development Aid at a Glance, Table 1.3.6. ODA by sector. 
Given that ODA is assumed to decline further in the near future for all three countries, the fact that most of Vietnam's recent ODA has gone to economic projects might be an opportunity, as ODA is more likely to be easily replaced by the private sector in economic projects than social ones. In other words, if the private sector can successfully replace ODA in the economic sector, the reduced future ODA can then be focused on the social sector and complement the existing ODA. Furthermore, given the reduced availability of ODA, the remaining ODA should focus on capacity development and civic actors to ensure less reliance on ODA in the future.

Table 2: Indicative World Bank lending to Vietnam, FY2018-FY2020 (\$ million)

\begin{tabular}{|c|c|c|c|c|}
\hline & $\begin{array}{c}\text { CPF } \\
\text { Focus } \\
\text { Area } \\
\end{array}$ & $\mathrm{IDA}^{\mathrm{b}}$ & IBRD & Other \\
\hline \multicolumn{5}{|l|}{ FY18 } \\
\hline Dynamic Cities Urban Development Project (IPF) & 1 & 330 & & \\
\hline HCMC Subnational DPOl & 1 & 100 & & \\
\hline PHRD Revenue Mobilization (IPF) & 1 & & & 4.2 \\
\hline Health Service Delivery Reform Project (IPF) & 2 & & 80 & 15 \\
\hline GPOBA Quality Deaf Education in Vietnam Project & 2 & & & 3 \\
\hline HCMC Flood Risk Management Project (IPF) & 3 & & 400 & \\
\hline $\begin{array}{l}\text { GEF Mekong Delta Integrated Climate Resilience and Sustainable } \\
\text { Livelihoods Project }\end{array}$ & 3 & & & 6 \\
\hline Vietnam HCFC Phase-out Project Stage II & 3 & & & 14.6 \\
\hline Power Sector DPO4 & 3 & 170 & & \\
\hline GCF Risk-sharing Facility for Industrial Enterprises & 3 & & & 80 \\
\hline Climate Change and Green Growth DPO2 & 3 & 90 & & \\
\hline FCPF North Central Coast Region Emission Reduction Program & 3 & & & 90 \\
\hline GEF Strengthening Partnerships to Protect Endangered Wildlife & 3 & & & 3 \\
\hline Subtotal & & 690 & 480 & 215.8 \\
\hline \multicolumn{5}{|l|}{ FY19/20 } \\
\hline Fiscal Governance DPO2 & 1 & 300 & & \\
\hline HCMC Subnational DPO2 & 1 & 100 & & \\
\hline Revenue Administration for Integration and Development (IPF) & 1 & 100 & & \\
\hline Agriculture Restructuring Project (DPO/IPF) & 1 & 100 & & \\
\hline Southem Region Waterways and Transport Logistics Corridor Project (IPF) & 1 & & 250 & \\
\hline Vietnam National University Project (IPF) & 2 & 100 & & \\
\hline EVN Solar Power Project (IPF) & 3 & & 200 & \\
\hline Distribution Efficiency II (IPF) & 3 & & 350 & \\
\hline Power Sector Reform DPO5 & 3 & 170 & & \\
\hline Mekong Delta Water Security Project (IPF) & 3 & & 400 & \\
\hline CAT-DDO & 3 & & 200 & \\
\hline Subtotal & & 870 & 1,400 & - \\
\hline
\end{tabular}

a. The indicative list is based on government-expressed demand for support and is not exhaustive. All IDAls transitional support will be programmed.

b. IDA transitional support on non-concessional (IBRD-like) terms.

Note: Exchange rate: 1 SDR = \$1.36 (March-April 2017 average).

Source: World Bank (2017), Country Partnership Framework for the Socialist Republic of Vietnam for the Period FY18-FY22, Table 3, p. 40.

According to a World Bank press release on April 5, 2018, ${ }^{23}$ the World Bank's Vietnam Country Partnership Framework (CPF) for fiscal year (FY) 2018 to FY2022 will focus specifically on the "economic integration of the poor and vulnerable groups" for which the World Bank will provide 
support for targeted interventions to expand economic opportunities for people in "remote and disadvantaged" areas. However, looking at Table 2, it is clear that many projects do not focus on the economic integration of the poor and vulnerable groups in remote and disadvantaged areas. For example, the Dynamic Urban Cities Development Project, for which $\$ 330$ million is allocated, constitutes nearly half of the non-concessional IDA allocations in FY2018.

There is some agreement among the interviewed informants that IDA graduation will have the biggest effect on poverty reduction, as this is the area in which almost every IDA dollar has been granted. Other majorly affected sectors will be health (especially HIV programs), education (especially for the most vulnerable groups in disadvantaged areas), gender equity (especially women rights), democracy, and governance. In these areas, it will be quite challenging for Vietnam to sustain the momentum and to make further progress.

As Figure 13 shows, while the share of all donor's ODA allocated to social infrastructure and services amounts to 29.2 percent during 2008-2016, IDA's allocation to social sectors amounts to 38.8 percent. On the other hand, the share of ODA allocated to economic sectors amounts to 45.5 percent compared with 40.5 percent for IDA. The share of ODA allocated to production sectors is relatively small for both all donors and IDA, while the share of ODA allocated to multi-sectors and others amounted to 17.3 percent for all donors and 11.8 percent for IDA. Examining the annual data from 2008 to 2016 shows that excluding 2009, when IDA's share in total ODA provided to Vietnam was 33 percent, IDA's share in total ODA remained relatively stable around 25 percent from 2008 to 2016.

Figure 13: Gross disbursements of ODA by sector for all donors and IDA (percent of total), average for 2008-2016

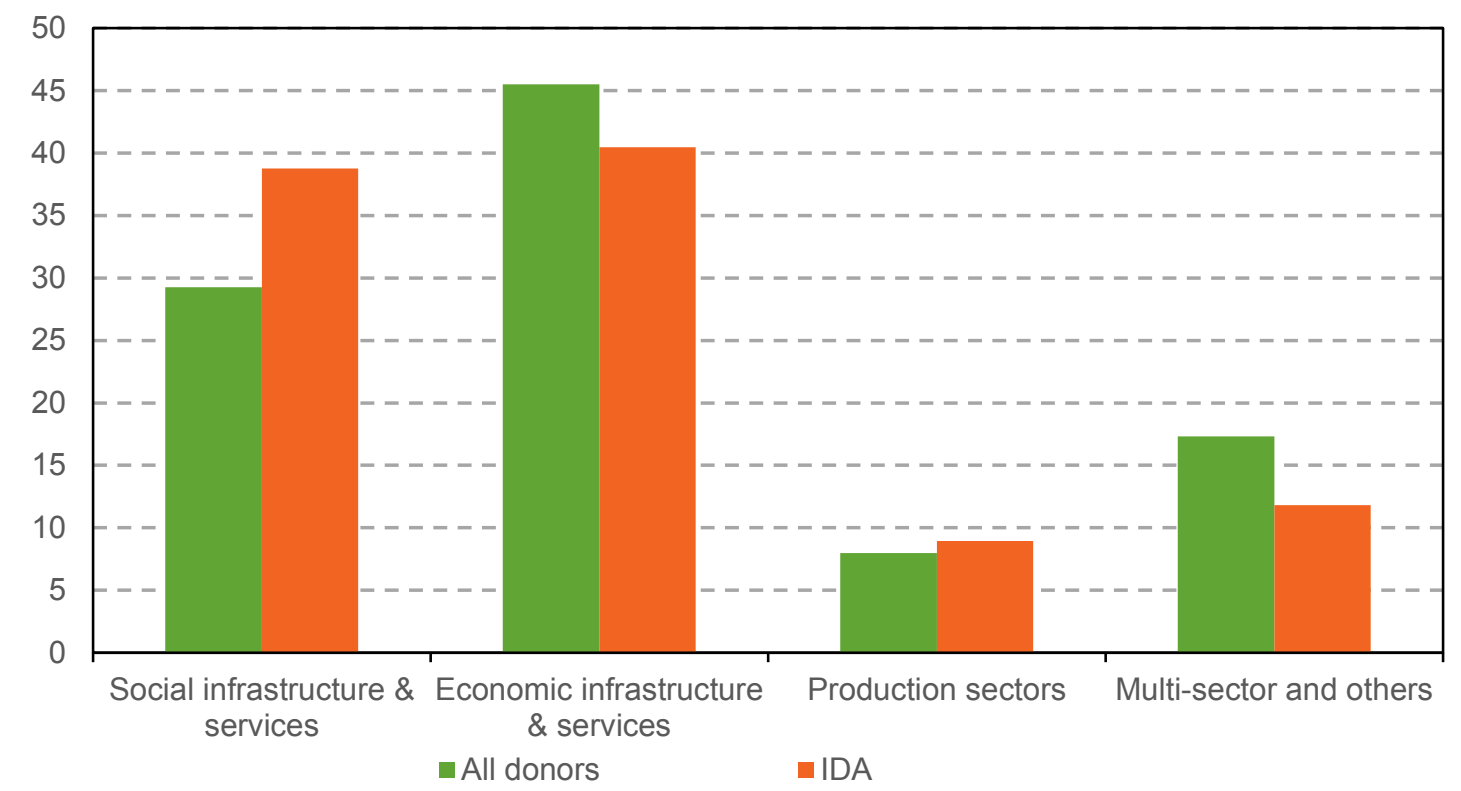

Source: Created by author based on OECD DAC CRS database.

Finally, Figure 14 shows that the share of ODA allocated to education is on a declining trend for both ODA provided by all donors and ODA provided by IDA, while the share of ODA allocated to health remained relatively stable overall. Taking into account that net ODA declined considerably to $\$ 2.89$ billion in 2016 (down from the 2011-2015 average of $\$ 3.84$ billion), we should have seen a reallocation of the reduced ODA towards social sectors. This is because social sectors have fewer opportunities to involve the private sector than for example the transport sector, where there are 
typically options to recover investments. On the other hand, Oxfam's own research beyond Vietnam demonstrates user fees related to private sector involvement in health and education have been shown to have detrimental impacts on poor communities and women and girls in particular.

Figure 14: Changes in the allocation of ODA to sectors over time (percent), 2008-2016 ${ }^{24}$
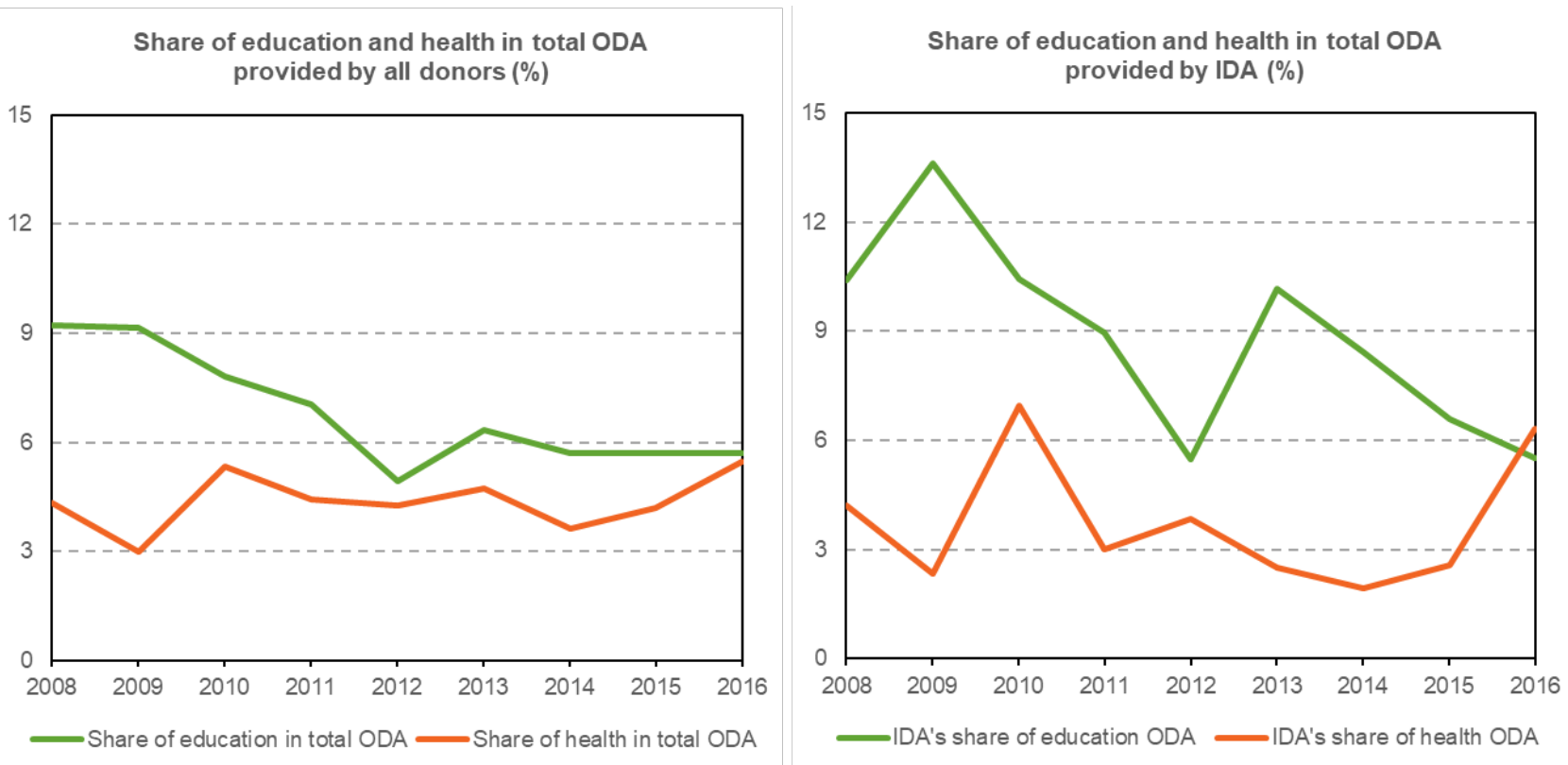

Source: Created by author based on OECD DAC CRS database.

\section{Sector-specific issues}

The following analysis provides a tentative assessment of how the expected reduction in ODA might affect the education, health, water, and agriculture sectors. It combines the limited information on which donors have left or reduced their provision of ODA to Vietnam with information on the donors' involvement in these four sectors.

\section{Education}

As shown in Figure 11 earlier, the average annual donor contribution to Vietnam's education sector was $\$ 186$ million during 2011-2015, which is broadly consistent with the 2016 commitments provided in Table 3 below. Furthermore, we also know that the average annual spending on education by the GoV was $\$ 8.275$ billion during 2011-2013. ${ }^{25}$ Taking this information together, it can be inferred that donors to Vietnam's education sector has been a marginal 2.25 percent. And given that Vietnam is no longer eligible for concessional IDA funds (which has been the largest donor for education by far), ODA for the education sector is likely to be reduced further.

What might explain this marginal involvement by the donor community? First, Vietnam already achieved universal primary education two decades ago, reaching net primary school enrollment of 99 percent in 1998 (even though it declined and then increased marginally after that). Second, there is some indication that Vietnam has maintained education quality during rapid expansion by ensuring that disadvantaged students receive relatively equitable access to quality schooling. As stated in the World Development Report (WDR) 2018 (p. 4), "Vietnam surprised the world when the 2012 results of the Programme for International Student Assessment (PISA) showed that its 15year-olds were performing at the same level as those in Germany." ${ }^{26}$ However, Vietnam's 
surprisingly good performance in the PISA study has since been explained by selective samples that exclude some poorly performing schools or students. ${ }^{27}$

Table 3: Donor contributions to the education sector (based on 2016 commitments)

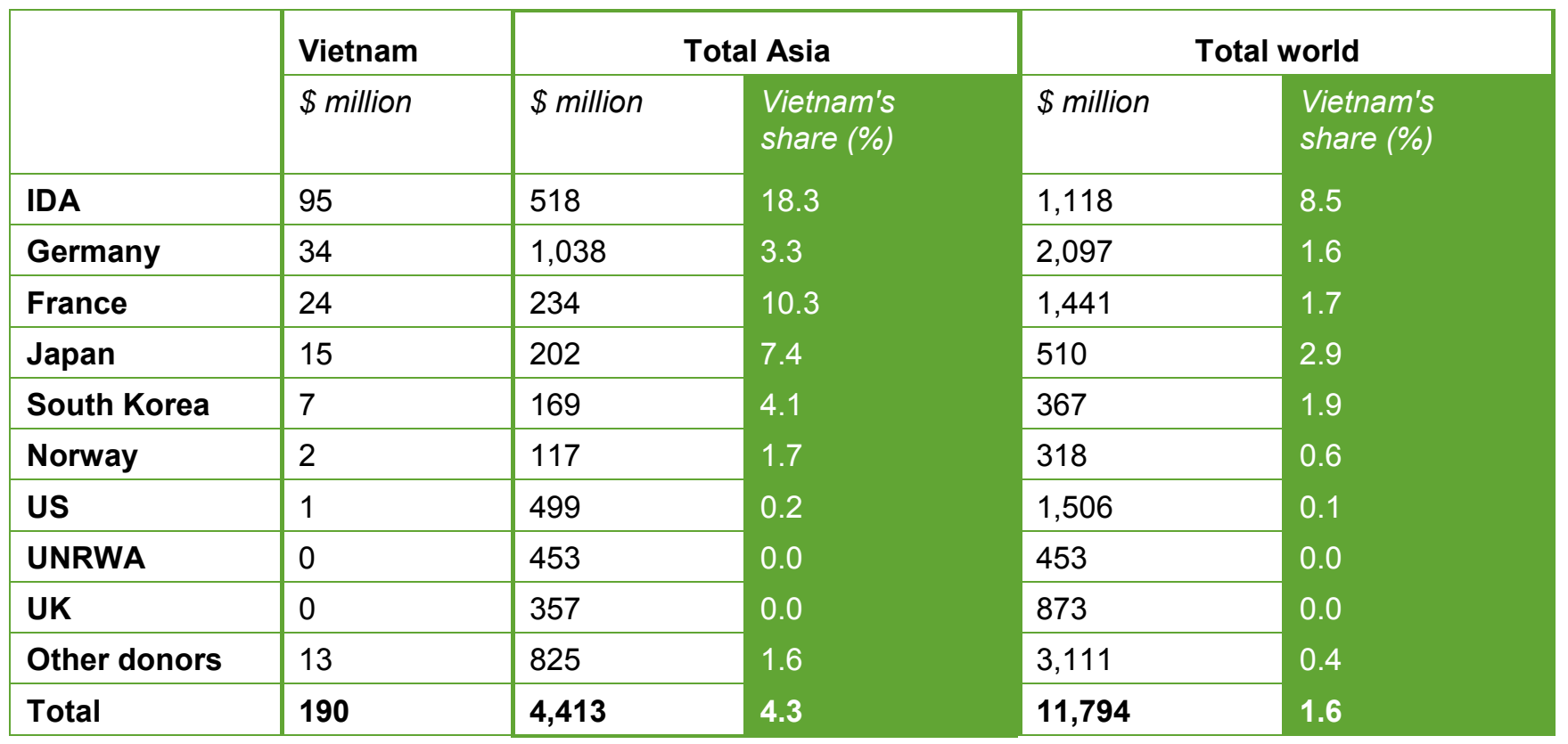

Source: Created by author based on OECD DAC (2018), Table 4.3.8 for top 10 donors in Asia and the World.

While reaching universal primary education is a critical milestone for LICs, it is far from enough to achieve the SDGs. Bodewig and Badiani-Magnusson $(2014)^{28}$ have shown that Vietnam's current challenge is to make its workforce more productive and better equipped with the skills needed for new job demands. Similarly, the Global Partnership for Effective Development Co-operation $(2016)^{29}$ has stated that future sustainable development will require continued investments in human capital. Furthermore, the ADB $(2017)^{30}$ has shown that MICs that succeed in reaching highincome status invest more in human capital than those that are trapped at MIC status.

The World Bank's Vietnam poverty assessment (2018) had also suggested that it is a priority for Vietnam to implement education reforms designed to equalize opportunities and develop workforce skills, which will help with further reducing poverty and promoting shared prosperity.

Despite the small share of ODA in the education sector, the further reduction of ODA does threaten it, as ODA's contribution goes beyond the monetary value to stimulating government spending towards and policy development for a more equitable education sector.

\section{Health and nutrition}

Although Vietnam is expected to eliminate extreme income poverty by 2030 (SDG1), its outlook for SDG2 (zero hunger) is still bleak. ${ }^{31}$ One of the reasons is that Vietnam still has far too many children with stunted growth, one of the indicators for SDG2. As Figure 15 shows, in 2010 (which is the last year such data is available) about one-quarter (23.3 percent) of all children under age five were stunted. This is one of many examples of how focusing on GDP per capita can be a misleading marker on how a country is doing. 
Figure 15: Prevalence of stunted height for children under five (percent), all available years

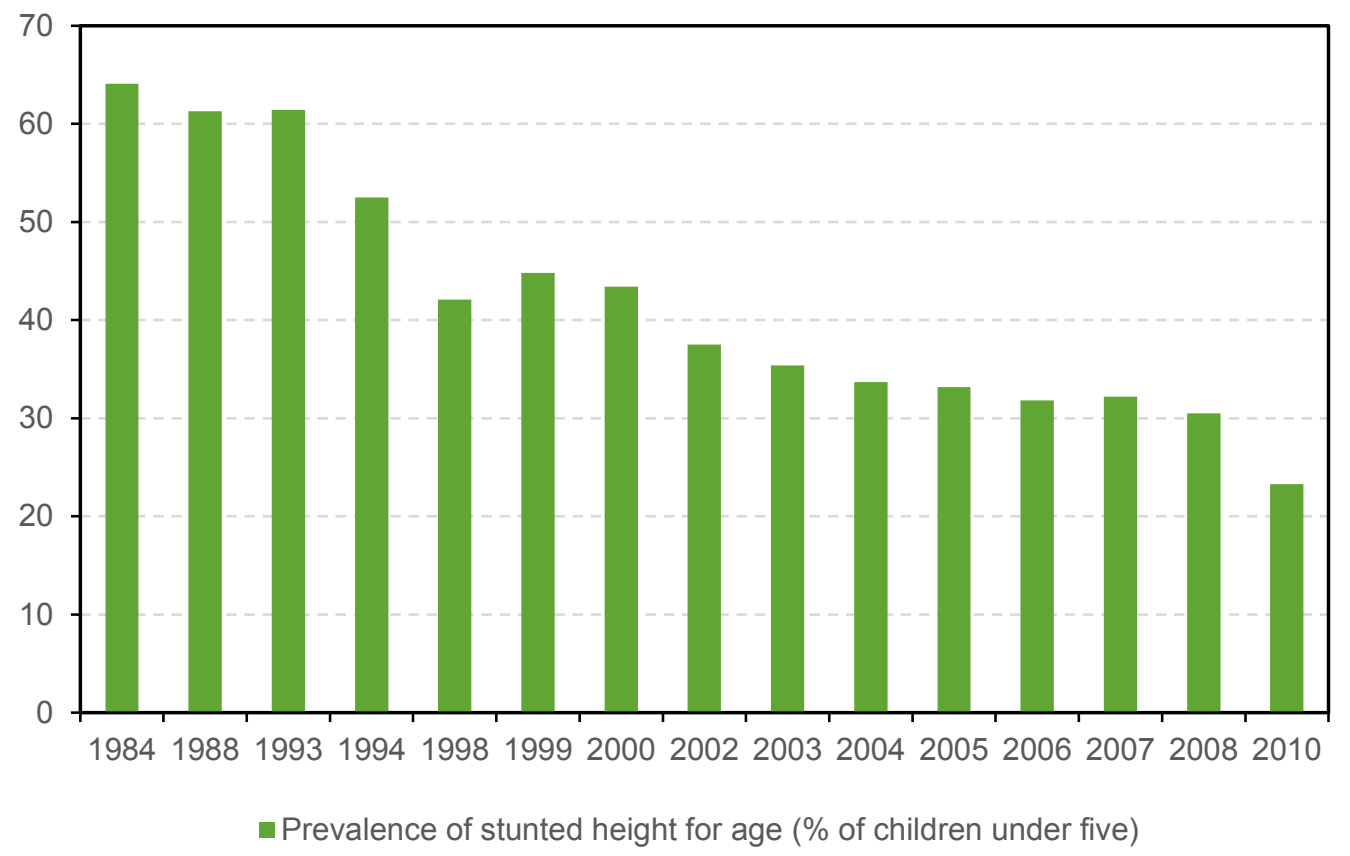

Source: Based on World Bank (2018), WDI/IDS database.

As Table 4 shows, donor contributions to the health sector in Vietnam are not only low in absolute terms (totaling $\$ 103$ million in 2016), they are also low relative to donor contributions to health in other Asian countries. Of the $\$ 3.45$ billion committed by donors to Asian countries, Vietnam received only 3 percent. And of that 3 percent, the US provided nearly half, a legacy of the Bush administration's President's Emergency Plan for AIDS Relief. If the US and other donors stop providing ODA to the health sector, some interviewees expressed concerns it would jeopardize the continuation of HIV programs, social work community stations, and other community health care activities. ${ }^{32}$ 
Table 4: Donor contributions to the health sector (based on 2016 commitments)

\begin{tabular}{|c|c|c|c|c|c|}
\hline & \multirow{2}{*}{$\begin{array}{c}\text { Vietnam } \\
\text { million }\end{array}$} & \multicolumn{2}{|c|}{ Total Asia } & \multicolumn{2}{|c|}{ Total World } \\
\hline & & $\$$ million & $\begin{array}{l}\text { Vietnam's } \\
\text { share (\%) }\end{array}$ & $\$$ million & $\begin{array}{l}\text { Vietnam's } \\
\text { share (\%) }\end{array}$ \\
\hline US & 47 & 663 & 7.1 & 9,248 & 0.5 \\
\hline Global Fund & 15 & 622 & 2.4 & 2,972 & 0.5 \\
\hline Japan & 11 & 434 & 2.5 & 724 & 1.5 \\
\hline Germany & 2 & 174 & 1.1 & 648 & 0.3 \\
\hline Canada & 2 & 156 & 1.3 & 798 & 0.3 \\
\hline South Korea & 2 & 141 & 1.4 & 239 & 0.8 \\
\hline WHO & 2 & 130 & 1.5 & 493 & 0.4 \\
\hline IDA & 0 & 280 & 0.0 & 1,325 & 0.0 \\
\hline EU institutions & 0 & 156 & 0.0 & 1,029 & 0.0 \\
\hline Other donors & 23 & 694 & 3.3 & 3,712 & 0.6 \\
\hline Total & 103 & 3,452 & 3.0 & 21,188 & 0.5 \\
\hline
\end{tabular}

Source: Created by author based on OECD DAC (2018), Table 4.3.12 for top 10 donors in Asia and the World.

\section{Water and sanitation}

Vietnam scores higher on SDG water indicators (SDG6) compared with similar countries. Yet it faces a number of challenges in providing universal coverage. ${ }^{33}$ As Figure 16 shows, as of 2015, 91 percent of Vietnam's population used at least basic drinking water services, though only 78 percent used at least basic sanitation services. Figure 16 also shows continuous progress during 2000 2015, which has been achieved due to considerable donor support. As Table 5 shows, in 2016, donor commitments to Vietnam's water sector were $\$ 531$ million, which is relatively high compared with the $\$ 190$ million committed to education and $\$ 103$ million to health. Furthermore, out of the $\$ 2.99$ billion that donors allocated to the water sector in Asia, Vietnam got 17.7 percent. However, given that more than half of these commitments to Vietnam came from IDA, Vietnam has by now lost more than half of the ODA in the water sector. While a recent (2016) World Bank report ${ }^{34}$ praised Vietnam as one of the few developing countries having spent a sufficient share of its GDP in the water and sanitation sector, much of this spending by the government has been induced by high donor support. With IDA gone as the key donor in the water sector, the government's spending on water and sanitation may be reduced. 
Figure 16: Percentage of people with access to safe water and sanitation, 2000-2015

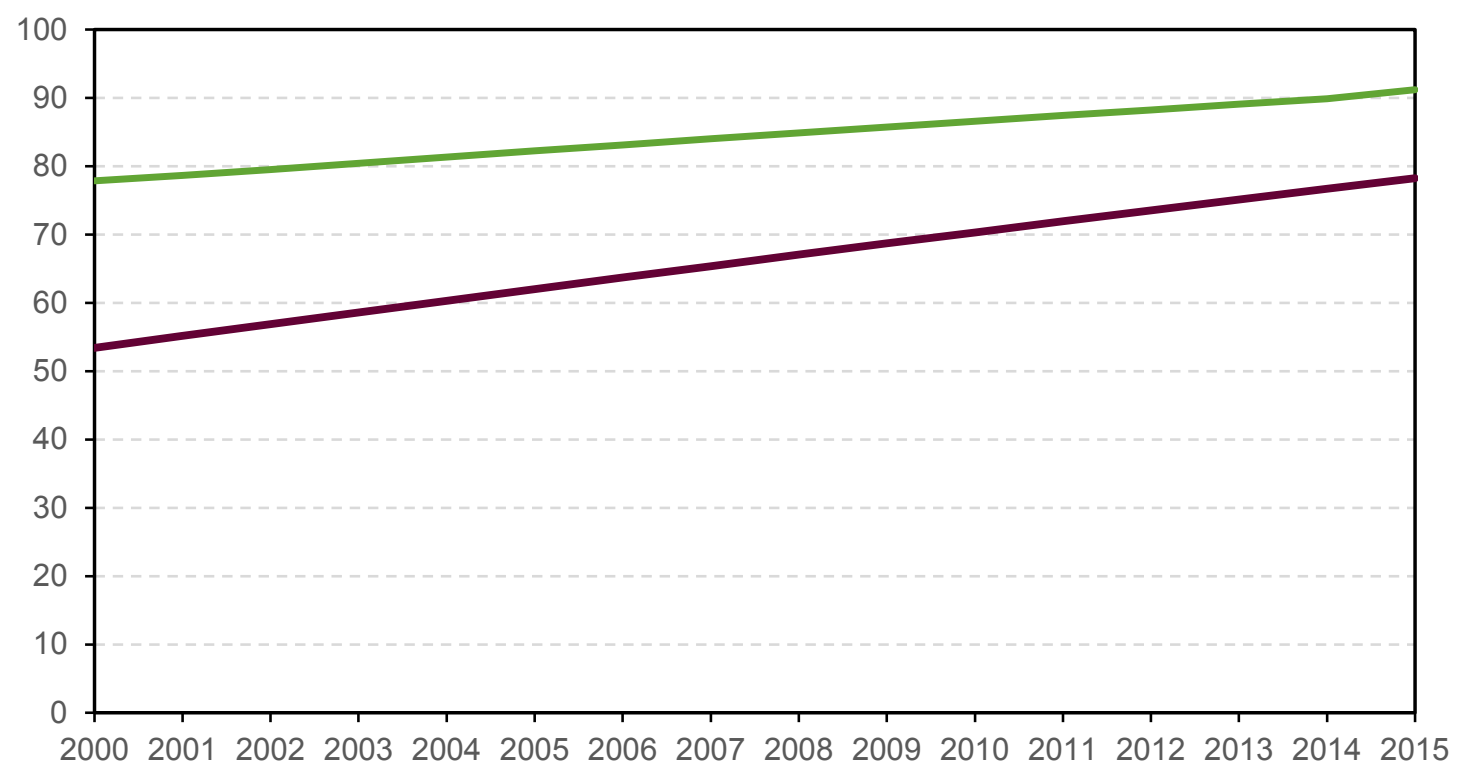

People using at least basic drinking water services (\% of population)

People using at least basic sanitation services (\% of population)

Source: Based on World Bank (2018), WDI/IDS database.

Table 5: Donor contributions to the water sector (based on 2016 commitments)

\begin{tabular}{|c|c|c|c|c|c|}
\hline & \multirow{2}{*}{$\begin{array}{l}\text { Vietnam } \\
\$ \text { million }\end{array}$} & \multicolumn{2}{|c|}{ Total Asia } & \multicolumn{2}{|c|}{ Total World } \\
\hline & & $\$$ million & $\begin{array}{l}\text { Vietnam's share } \\
(\%)\end{array}$ & $\$$ million & $\begin{array}{l}\text { Vietnam's } \\
\text { share (\%) }\end{array}$ \\
\hline IDA & 272 & 616 & 44.2 & 1,095 & 24.8 \\
\hline Japan & 206 & 980 & 21.0 & 1,327 & 15.5 \\
\hline ADB & 27 & 122 & 22.1 & 122 & 22.1 \\
\hline Germany & 6 & 224 & 2.7 & 654 & 0.9 \\
\hline Australia & 4 & 46 & 8.7 & 59 & 6.8 \\
\hline France & 1 & 241 & 0.4 & 846 & 0.1 \\
\hline South Korea & 0 & 176 & 0.0 & 269 & 0.0 \\
\hline US & 0 & 154 & 0.0 & 380 & 0.0 \\
\hline EU institutions & 0 & 128 & 0.0 & 746 & 0.0 \\
\hline Other donors & 15 & 306 & 4.9 & 1,698 & 0.9 \\
\hline Total & 531 & 2,992 & 17.7 & 7,195 & 7.4 \\
\hline
\end{tabular}

Source: Created by author based on OECD DAC (2018) Table 4.3.16. for top 10 donors in Asia and the World. 


\section{Agriculture}

Even though the share of agriculture (value added) in GDP has decreased considerably during the last few decades (the available data shows a decline from 21.0 percent in 2010 to 18.1 percent in 2016), agriculture is still the largest sector for employment. In 2017, 40.9 percent of those aged 1564 and in employment were employed in agriculture, while 25.1 percent were employed in industry, and 34.0 percent in the service sector. There is also a gender gap for employment in agriculture, with 42.4 percent of all women employed in 2017 working in agriculture compared with only 39.5 percent for men. Agriculture is also the predominant sector where children work. In 2012 (which is the only year such data is available), 77.1 percent of all economically active children aged 7-14 were working in agriculture. ${ }^{35}$

As Figure 17 shows, gross disbursements of ODA to agriculture have remained relatively stable in current US dollar terms. From 2008 to 2016 , they averaged $\$ 204$ million for all donors and $\$ 59.2$ million for IDA (which implies that IDA's average share among all donors has been 29.1 percent). However, considering that agriculture still contributes to 40.9 percent of total employment and 18.1 percent of GDP, the share of ODA provided to agriculture in total ODA was relatively low during 2008-2016, averaging 5.1 percent for all donors and 5.8 percent of IDA. Given that most of Vietnam's poor remain in the rural areas, investments in agriculture are at least twice as effective in reducing poverty than investments in other economic sectors (i.e., industry and services). ${ }^{36}$

Figure 17: Gross disbursements of ODA for agriculture (\$ million), 2008-2016

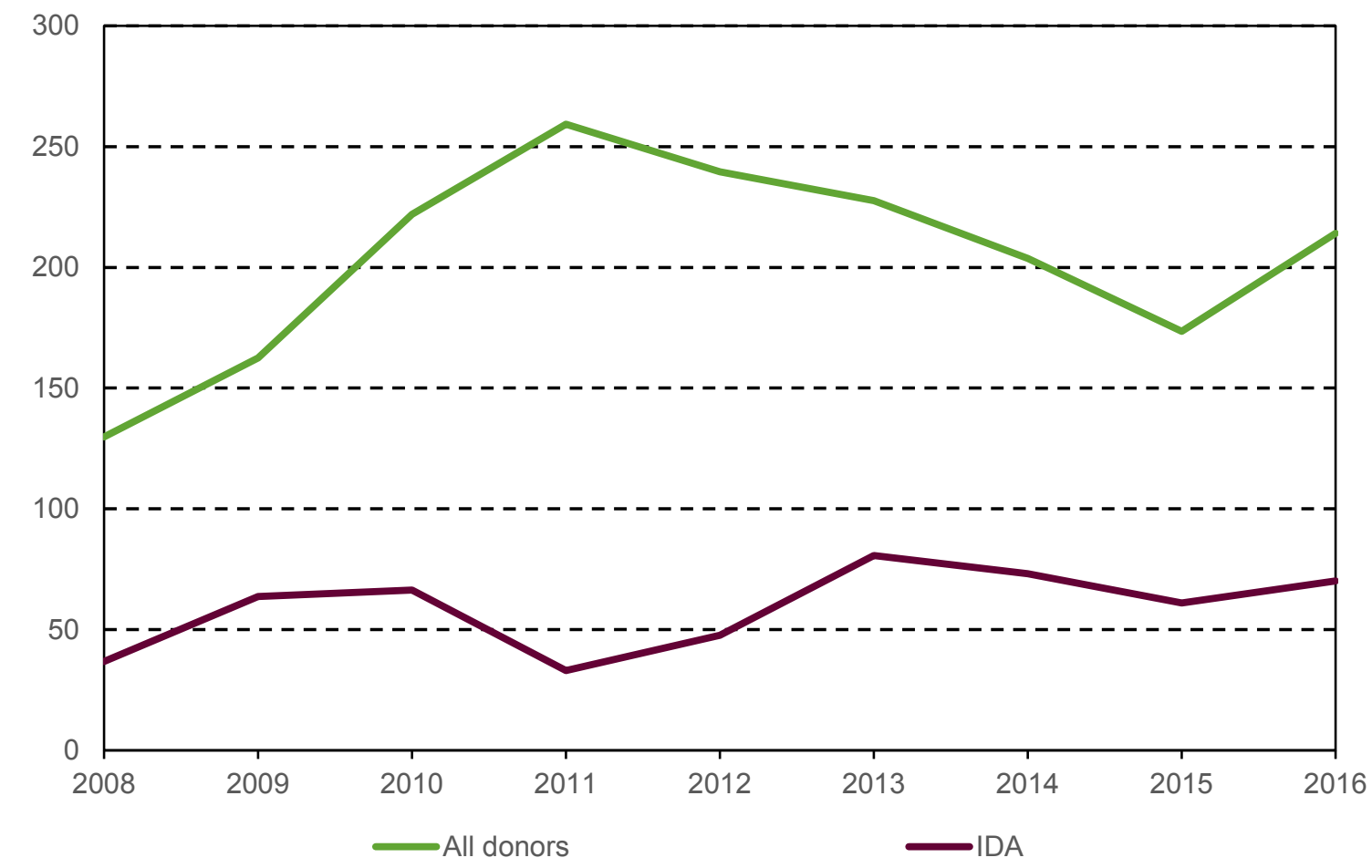

Source: Created by author based on OECD DAC CRS database. 


\section{Gender equality}

Vietnam has less severe gender discrimination than its neighboring countries. ${ }^{37}$ Vietnam has also made substantial achievements in promoting and advancing gender equity since the early 1990s. Though the monetary amounts of ODA specifically targeted at gender equity are small, donors have made a lasting impact by introducing new gender equality concepts, ideas, and terms; raising gender awareness; setting up legal, regulatory and institutional frameworks; and collecting gendered data sets. According to a senior researcher at the Vietnam Institute for Social Development Studies (ISDS), ODA has greatly facilitated changes by bringing in new ideas for reform, promoting certain groups of reformists, and creating evidence for policy dialogue among various parties, all of which did not exist before. Many ODA-financed programs influenced the government's policy and decision-making process, which resulted in pro-reform policies, laws, and legal documents. Although the gains attributed to ODA were made possible by a longer history of gender equality in Vietnam than in its neighboring countries. ${ }^{38}$

Declining ODA poses challenges for Vietnam to maintain its progress towards gender equality. First, there are difficulties in enforcing gender-equal policies and legal requirements pertaining to gender equality advancement. For instance, women are still paid 11 percent lower than men for similar work. As well as this, 7.8 million female laborers work in poor conditions in the informal economy, and women make up more than 57 percent of the unemployed among unskilled laborers. ${ }^{39}$ These issues are unlikely to be resolved without external aid and technical support, as neither market forces nor current government policies are sufficient to change them.

Second, the changes in people's mindsets related to gender awareness remain largely superficial and at times formalistic. The superficial gender awareness permeates within the state as well, thus preventing the translation of good policies/laws into actions. Women remain under-represented in leadership positions, with only 26 percent of such positions occupied by women. Meanwhile, women take on more than 52 percent of manual labor and 66.6 percent of household work. ${ }^{40}$ Third, government spending for gender equity activities is too thin and covers only administrative expenses. Almost all gender equity activities such as advocacy, advisory, policy dialogues, research, and generation of evidence have been financed by external funds. Fourth, many of the reform champions in Vietnam have or will soon be retired, thus losing their direct influence, and it is not clear if and to what extent new reform champions will appear in the post-IDA context. Fifth, there is a lack of investment in capacity building and institutional strengthening of CSOs, who deliver on gender mainstreaming. For example, Oxfam has recently offered the GoV a gender responsive budgeting framework, which helps them to see the differential gender impact of policies.

In summary, Vietnam's transition away from ODA poses significant risks to continued progress towards gender equality in Vietnam. To mitigate these effects, the ISDS researcher suggested that more attention be paid to grassroots women's movements, which are growing and have been facilitated by social media, and to savings and credit groups focusing on women. The ISDS researcher also suggested substantially revising Government Decree 93/2009/ND-CP to help local CSOs have easier access to grant money by donors, such as the European Union (EU) and some embassies, so they can continue with gender equity activities. 


\subsection{HOW IS THE VIETNAMESE GOVERNMENT ADAPTING TO THE DECREASE IN CONCESSIONAL FINANCE?}

The Vietnamese government has detailed its intention to focus on the attraction, management, and use of ODA and concessional loans from foreign donors during 2016-2020 in Decision 251 (dated February 17, 2016). Decision 251 states that "Vietnam has advocated mobilization of all resources for development investment of which ODA and concessional loans from foreign donors remain vital" to accomplish the socio-economic development tasks during the 2016-2020 period. According to the GoV, the total demand for ODA and concessional loans in 2016-2020 is \$39.5 billion, mainly for projects on transport, urban development, agriculture and rural development, environment, education and training, health, and science and technology. The government expects total disbursement of ODA and concessional loans in 2016-2020 of \$25 billion to $\$ 30$ billion, equal to $\$ 5$ billion to $\$ 6$ billion per year on average, which is 14 percent higher than in the 20112015 period.

However, the GoV is cautious of the likely longer-term decline in ODA and has therefore stressed that Vietnamese development agencies must be careful in making decisions on using nonconcessional loans in order to achieve investment efficiency and ensure public debt safety. Decision 251 also states that since Vietnam became a LMIC in 2010, the development cooperation environment is beginning to change gradually from aid relationships to partnerships.

Decision 251 also describes how Vietnam's development partners are expected to change their development cooperation policies depending on whether these development partners end or continue with the provision of ODA. The GoV expects that development partners that have ended their provision of ODA shall focus mainly on stepping up the development of trade relations and investment cooperation with Vietnam through bilateral and multilateral trade and investment agreements, including free-trade agreements.

The GoV expects development partners that continue to maintain ODA programs for Vietnam to make adjustments to their policies to "match the new development cooperation environment" (i.e., be determined by the aid recipient). Alongside this, they expect partners to continue to support Vietnam in policy-making and institutional strengthening; climate change and natural disaster risk reduction; poverty reduction; small-scale investment projects in the health, education and training sectors; and supporting global commitments like the SDGs.

While Decision 251 contains specific details of key targets for ODA during 2016-2020, any reference to support for non-state actors' development activities, such as Vietnamese CSOs' work on poverty reduction, gender equality, and human rights, is conspicuously missing. Decision 251 has detailed plans within the following five areas, which have been prioritized to ensure the attraction and correct management and use of ODA and concessional loans in the 2016-2020 period:

1. Help break through the implementation of the strategy for construction of consistent and modern infrastructure;

2. Support research, construction of socio-economic and cultural development policies and fostering state administration capacity;

3. Support development of human resources for scientific research and technological development; 
4. Support environmental protection, responses to climate change and implementation of strategy for green growth; and

5. Use as the state's capital investment in projects in the form of public-private partnerships; and

Finally, Decision 251 also states that "ODA and concessional loans shall be used to support realization of development visions for geographical territories according to the 2016-2020 socioeconomic development plan, with priority given to localities facing economic difficulties."

Beyond the stipulations in Decision 251, the recent decline in ODA has been compensated mostly by an increase in domestic borrowing (see details in Annex IV). However, the management of Vietnam's public financial sector is relatively weak and Vietnam's banking sector is vulnerable. The mobilization of domestic revenue for development is therefore necessary, even though it is challenging in present circumstances. Education and health still need more investment and spending. Limited ODA funds should focus on social sectors that are not likely to attract nonconcessional lenders. In doing so, the ODA funds can promote gender equality and support domestic resource mobilization (DRM) efforts. As ODA declines, support for a more diverse development finance portfolio should become a major focus of the government and donors alike. It is critical that DRM occurs in a progressive, equitable and transparent way to ensure no further increase in inequality. International and domestic civil society should carefully monitor and advocate gender equality in Vietnam to ensure that past gains are maintained. 


\section{PUBLIC DEBT AND PUBLIC DEBT SUSTAINABILITY}

In addition to the risks Vietnam's IDA graduation poses to its continued progress, as detailed in the last section, this section illustrates that the decline in concessional financing also poses significant risks to Vietnam's public debt sustainability. This section is structured into two main parts: Section 3.1. reviews the recent trends in Vietnam's public debt, and Section 3.2. analyzes the sustainability of Vietnam's public debt.

\subsection{RECENT TRENDS IN VIETNAM'S PUBLIC DEBT}

As was shown earlier, the amount lent to Vietnam through concessional loans has been declining during the last few years. To compensate for the decrease in concessional loans, the GoV has increased its non-concessional debt, mainly via sovereign external bonds, loans from foreign commercial banks, and domestic bonds and loans (see details in Annex II), which are all part of what is called public and publicly guaranteed (PPG) debt.

As shown in the left panel of Figure 18, Vietnam's total public debt increased from $\$ 74.5$ billion in 2012 to $\$ 125.6$ billion in 2016 , which is an increase of 68.5 percent in only four years. And given that the newly contracted debt is less concessional (i.e., comes with higher interest rates), this implies that the government must be spending more on debt service and therefore has fewer resources available for critical development interventions.

Figure 18: Evolution of PPG debt (\$ billions and percent of GDP), 2012-2016
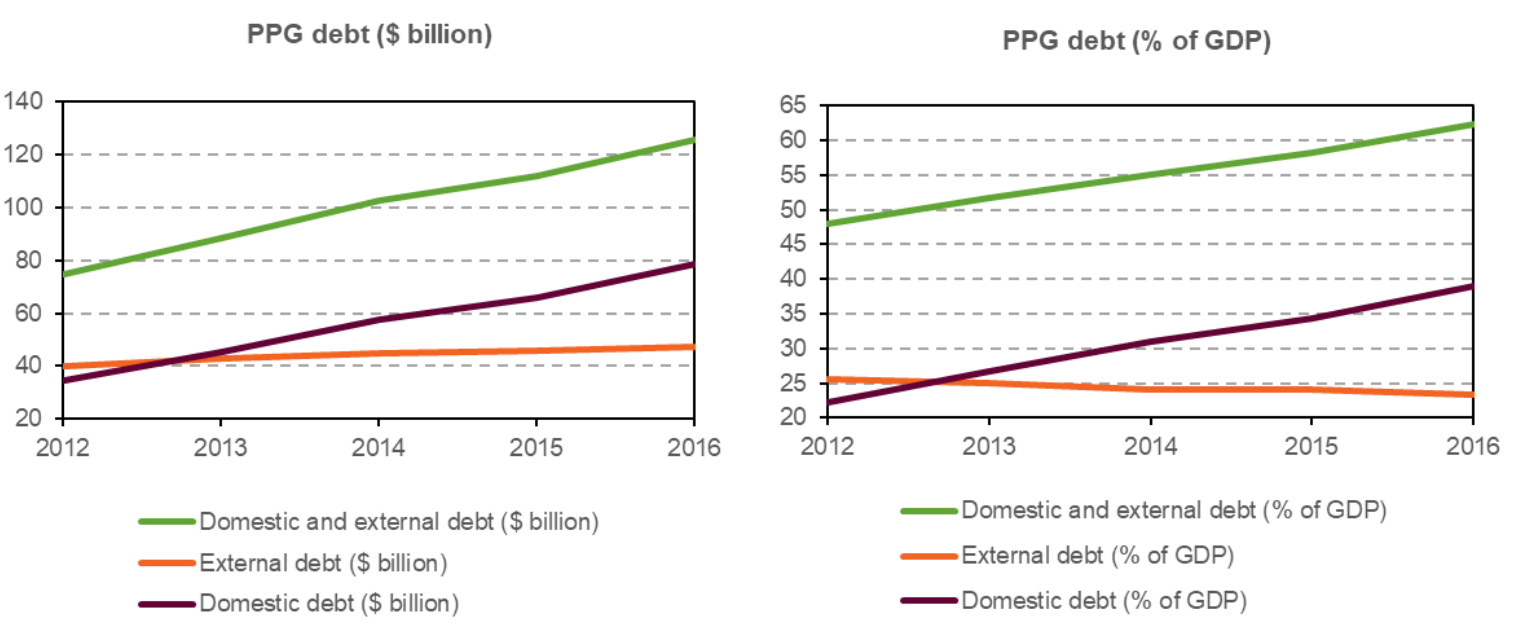

Source: Compiled based on World Bank (2018), WDI/IDS database.

As the right panel of Figure 18 shows, this sharp increase in Vietnam's PPG debt looks slightly better if looking at the debt-to-GDP ratio, which is a more accurate way to examine debt sustainability than looking at absolute debt figures. Still, the growth rate of total public debt has been considerably higher than the growth rate of GDP. The ratio of total public debt to GDP 
increased from 47.9 percent in 2012 to 62.4 percent in 2016. The IMF (2017) Staff Report projected that the stock of total public debt-to-GDP ratio will be 63.8 percent by the end of $2018 .{ }^{41}$

In order to get a better idea of the fiscal sustainability of Vietnam's public debt, Figure 19 shows the interest payments on public debt, respectively as percent of GDP and as percent of government revenues, which provides a more accurate picture. Given that domestic debt is typically not concessional, the sharp increase in public domestic debt (shown in the previous figure) sharply increased interest payments. The ratio of interest payments on domestic public debt to GDP increased by 145.2 percent from 2012 to 2016 . Since government revenues have risen slightly over the same period relative to GDP, the rise in the interest payments-to-revenue ratio is less than the rise in the interest payments-to-GDP ratio. However, the ratio of interest payments on domestic debt to revenues has still more than doubled from 3.7 percent in 2012 to 7.6 percent in 2016. These trends are obviously not sustainable in the long run. With the further decline in ODA, these ratios are expected to increase further, at least in the medium term.

If the GoV is committed to achieving the SDGs, ${ }^{42}$ it will require an increase in public investment. Some parts of the SDG agenda may be financed by private sector resources, although those investments can bring different burdens to the Vietnamese population (see section 5.1 for more information). With a likely decline in the flow of ODA, the GoV will need to either rapidly increase its DRM or else rely more and more on far more expensive non-concessional financing, which will not only impact the availability of revenues (like via higher interest payments), but also Vietnam's debt sustainability.

Given that Vietnam's public debt-to-GDP ratio is already near its legislative cap of 65 percent, the GoV has two main options: (a) increasing domestic revenues to a level that will allow for making the needed priority public investments to achieve the SDGs, or (b) if public resources cannot keep pace, the government will be unable to make these needed investments. In either option, it will be a challenge to keep debt levels at current levels. The GoV and its external development partners are fully aware of these challenges. ${ }^{43}$ 
Figure 19: Interest payments on PPG debt (percent of GDP and revenues), 2012-2016

Interest payments on PPG debt $(\%$ of GDP

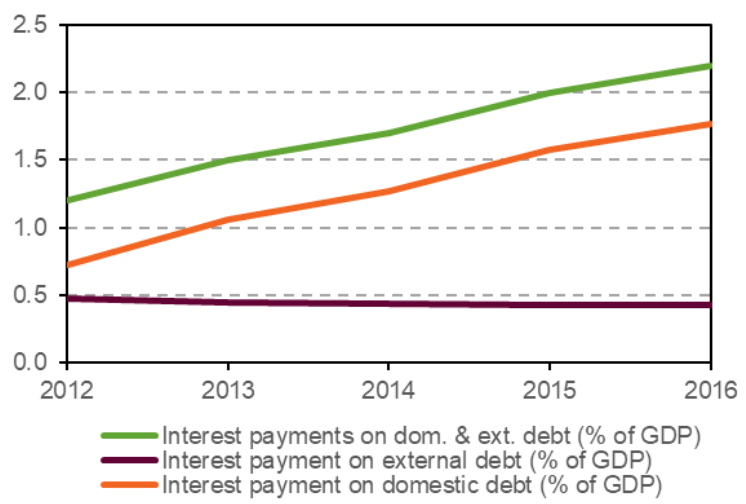

Interest payments on PPG debt

( $\%$ of government revenues)

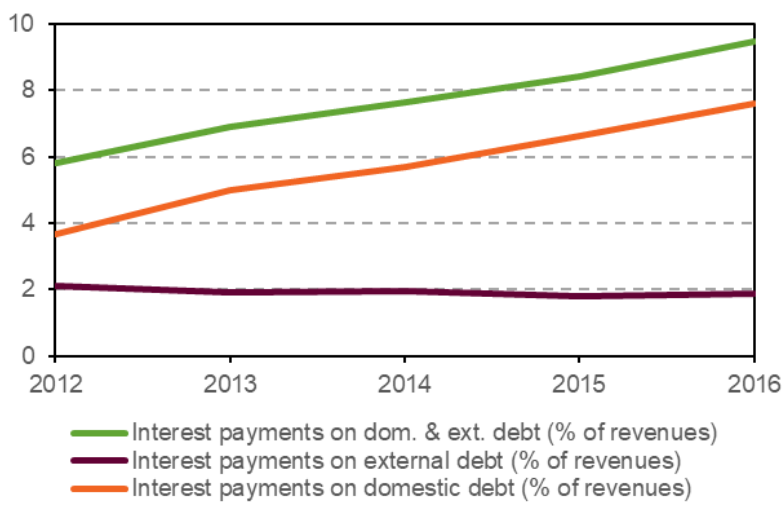

Source: Compiled based on World Bank (2018), WDI/IDS database.

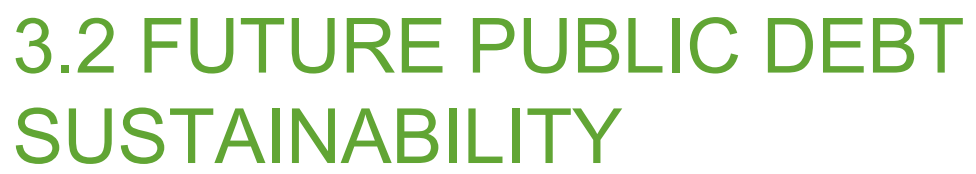

In order to test the feasibility of the above options, the following debt sustainability analysis provides some more concrete figures on what the impact of Vietnam's changing development finance portfolio might be. We make use of a debt projection module developed by Gunter, Lopez, Ramadas and Wodon (2002) ${ }^{44}$ to simulate the evolution of Vietnam's debt from 2015 to 2030 , based on initial conditions in 2015; projections for government expenditures, government revenues, and interest rates; the maturity of public debt; and a variety of other macroeconomic parameters. However, given that the results of any debt sustainability analysis are always based on subjective assumptions made for a variety of future macroeconomic indicators, the main purpose of this debt sustainability analysis is not to focus on the specific future values of debt indicators, but to examine how much the projected values of key debt indicators change as Vietnam continues to replace concessional debt with non-concessional debt. We therefore apply the same macroeconomic projections for two alternative scenarios:

- Scenario 1 assumes that the level of concessional debt will gradually decrease from its current (average 2014-2016) level to zero concessional debt by 2030.

- Scenario 2 assumes that there is no change in the level of concessionality of its public external debt (it stays as it was during the average of 2014-2016).

Just to make sure there is no misunderstanding, given that the underlying assumptions of any debt sustainability analysis (DSA) rarely hold true, neither of these two scenarios are provided as realistic outcomes. However, comparing these two scenarios (which are robust across alternative macroeconomic assumptions) sheds light on the impact of reduced concessionality of Vietnam's public debt. Furthermore, given that the main purpose of this DSA is to shed light on the impact of reduced concessionality of Vietnam's public debt, we have refrained from complicating the results with arbitrary assumptions related to possible contingent liabilities and macroeconomic shocks. 


\section{Debt sustainability indicators}

We limit the analysis to Vietnam's fiscal sustainability for two reasons: First, Vietnam's exports-toGDP ratio is 93.6 percent, which is far above the average for low-, middle- or high-income countries, implying that Vietnam is unlikely to face an unsustainable external debt in the near future. Second, we are more interested in analyzing how the move away from concessional public debt will affect the government's ability to finance development.

Even though Vietnam is no longer a LIC, it still has considerable amounts of concessional external debt stocks, and so we calculate the debt stock indicators in both net present value (NPV) and nonNPV terms ${ }^{45}$ It also makes sense to express debt stock indicators in NPV terms to see the true fiscal burden of Vietnam's move away from concessional debt. Hence, we examine the evolution of five key debt indicators (all in percent):

- total (domestic and external) public debt to GDP;

- total (domestic and external) public debt to government revenues;

- NPV public debt to GDP;

- NPV public debt to government revenues; and

- debt service on total public debt to government revenues.

The first two indicators are standard debt indicators for middle- and high-income countries; the third and fourth indicators are standard debt indicators for LICs; and the fifth indicator is a standard public debt indicator for any country.

\section{Macroeconomic assumptions (of both scenarios)}

This DSA assumes that Vietnam's GDP growth rate remains constant at 6.29 percent, which was the average annual GDP growth rate from 2014-2016. It also assumes that the government revenue-to-GDP ratio remains constant at its three-year average over 2014-2016, which was 23 percent; and that the government expenditure-to-GDP ratio remains constant at its three-year average over 2014-2016, which was 29.5 percent. In other words, the DSA assumes that the overall government deficit remains constant at 6.5 percent of GDP. There are three main reasons for this assumption. First, as was shown in the last section, the medium-term trend in the revenueto-GDP ratio is clearly downward, though the GoV should be able to stabilize it over the longer term. Second, the investments needed to achieve the SDGs will require the expenditure-to-GDP ratio at least to stay at its current level. Third, while we are interested to see what happens to Vietnam's public debt under these assumptions, the more important purpose of this analysis is to see the impact of the changing level of concessionality. This was done by:

- gradually increasing the average interest rate on external public debt from the current 1.79 percent to 4.7 percent by 2030 , and

- gradually decreasing the average maturity on external debt from the current 29.13 years to 10 years by 2030.

All the other initial values of the required macroeconomic variables for the DSA are based on threeyear averages (2014-2016, the latest available data when the DSA was done) and stay the same for both scenarios. The DSA also assumes that the government's ratio of domestic to external financing remains constant at its annual $2014-2016$ average. ${ }^{46}$ Given that this DSA makes projections over 15 years (which is different from the IMF's DSA five-year projections), using initial values that are three-year averages (2014-2016) is crucial to ensure the results aren't arbitrary. 


\section{Results of the DSA}

Figures 20 and 21 show the results of the assumptions described above for the two scenarios for our five debt indicators:

- total public debt to GDP (in percent) in NPV and non-NPV terms (the blue lines),

- total public debt to revenues (in percent) in NPV and non-NPV terms (the green lines), and

- debt service on total public debt to revenues (in percent; the red line).

In scenario 1 (a gradual decline of concessional debt, Figure 20), the debt-to-GDP ratio increases from about 60 percent in 2015 to nearly 90 percent in 2030 . This is 25 percentage points above Vietnam's current legal limit of 65 percent, which is however very difficult to enforce as debt dynamics cannot be legislated. What could be legislated is the size of the government deficit, which has, however, not been adopted by the GoV. In NPV terms, the percentages are only initially lower, because NPV debt and nominal debt are the same with zero conditionality. Similarly, the debt-torevenues ratio (shown on the right vertical axis) increases from about 280 percent in 2015 to nearly 430 percent in 2030 (in non-NPV terms). And the debt service-to-revenues ratio (shown on the left vertical axis) is projected to increase from 41 percent in 2015 to 75 percent in 2030 . None of these debt indicators can be considered to represent a sustainable debt. It should be stressed that none of these indicators are realistic, as the GoV would likely cut expenditures a long time before reaching the debt levels presented. Instead of making arbitrary assumptions on what future expenditures changes might be, the assumptions used in this DSA are based on historical values and the results intended to provide an important reference point when compared with scenario 2 .

In scenario 2 (no change in the level of concessionality, Figure 21), the NPV debt-to-GDP ratio would also increase by 2030 , but only to about 73 percent compared with nearly 90 percent in scenario 1. Similarly, the NPV debt-to-revenues ratio would increase to about 350 percent (compared with 430 percent in scenario 1), and the debt service-to-revenues ratio would increase to about 57 percent (compared with 75 percent in scenario 1). In other words, while the scenario of keeping the concessionality levels stable still increases all debt ratios, the far smaller increases in these ratios might be considered sustainable for the upper-middle-income country Vietnam could be in 2030 . 
Figure 20: Results of the DSA with zero concessional debt by 2030

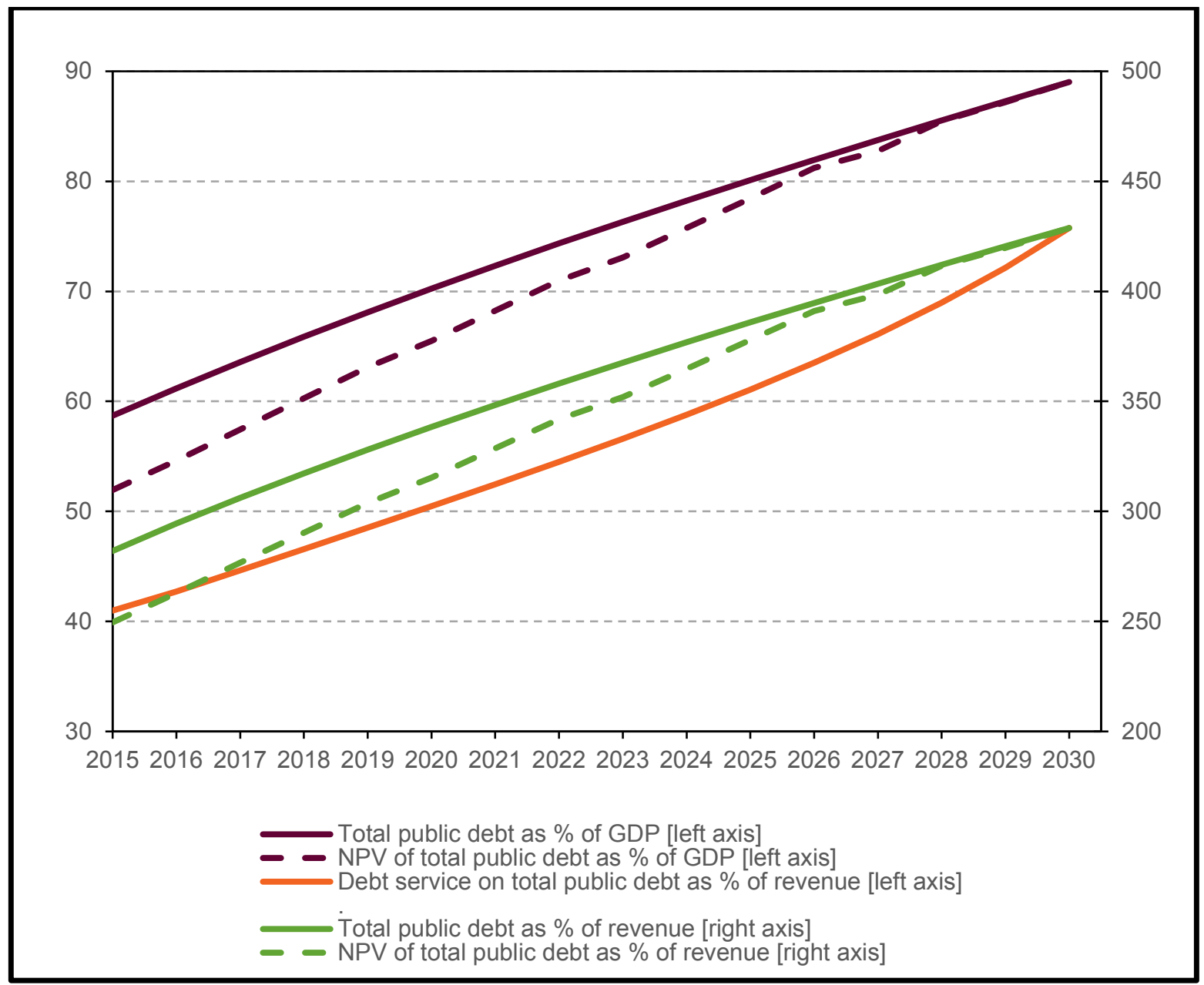

Source: Results based on DSA. 
Figure 21: Results of the DSA when keeping the level of concessionality as in 2015
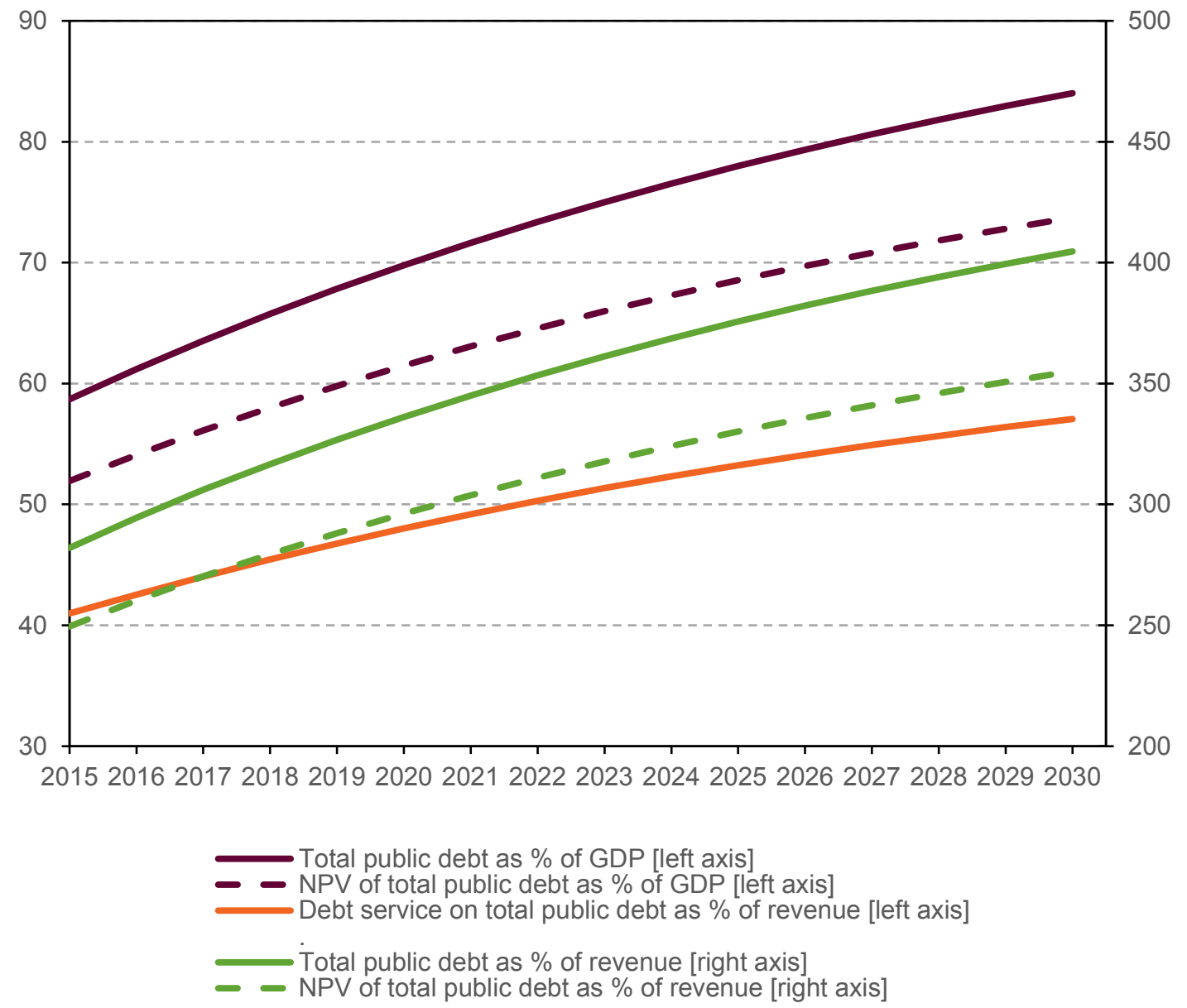

Source: Results based on DSA.

These results are largely independent of any specific assumption about GDP growth, with government deficits fixed at 6.5 percent of GDP. ${ }^{47}$ Lower future government deficits would, of course, result in lower debt levels than deficits of 6.5 percent. However, even a gradual reduction of the deficit from its current 6.5 percent to 3.5 percent in 2030 would still see the debt-to-GDP ratio increase to above 70 percent if gradually reducing the level of concessionality to 0 percent by 2030 . In other words, if the GoV wants to keep its debt sustainable, it will need to take at least one of three actions: (i) massively increase its revenue-to-GDP ratio, (ii) massively decrease its expenditure-to-GDP ratio, and/or (iii) massively increase the concessionality of its public external debt.

The second action would entail cutting expenditure, which would not allow Vietnam to undertake the priority public investments that are required to achieve the SDGs and would have other far-reaching social consequences, such as increased inequality. If the third action of continued concessional financing for social sectors is unavailable, the only remaining option is to massively increase domestic revenues. Though this cannot be achieved overnight, it can be attained over the medium term if the Vietnamese government is committed to boosting DRM, especially by adopting new and progressive taxes on rich individuals and corporations. 


\section{RESPONSIBLE EXIT STRATEGIES FOR AID DONORS}

This section examines what responsible exit strategies look like for aid donors by (1) examining when the time is right for donors to withdraw ODA from a country, (2) reviewing what IDA's current graduation criteria are, and (3) what lessons have been learned from previous IDA graduations.

\subsection{WHEN IS THE TIME RIGHT TO WITHDRAW ODA?}

The seemingly simple answer to the question of when the time is right for donors to withdraw ODA from a country is when (a) poverty has been reduced to an agreed minimum level and (b) the loss of ODA will not threaten the progress made. It would then need to be determined what the exact indicators are for these two criteria.

There are two measurement issues related to reducing poverty to some minimum level. First, what poverty measure should be used? Are we referring to extreme poverty (defined at PPP $\$ 1.90$ a day) or another less extreme definition of poverty, such as PPP $\$ 3.20$ a day? Second, how do we define that minimum level? For example, would a poverty rate of less than 1 percent be considered to meet that minimum level?

The question of which poverty measure to use is related to the question of an acceptable minimum level of poverty. It might make sense to use more than one poverty measure and more than one level. For example, a country might be considered to have reached an acceptable minimum level if the poverty rate at $\$ 1.90$ a day has fallen below 1 percent and the poverty rate at $\$ 3.20$ a day has fallen below 5 percent. Finally, given that poverty is a multidimensional phenomenon, these poverty measures should go beyond income poverty.

There are many more complex issues related to how to determine if the termination of ODA will not threaten future progress. In the case of Vietnam, the impact of losing access to concessional aid on its debt sustainability is the most relevant. And as shown earlier, the loss of access to concessional aid is indeed threatening Vietnam's future progress.

One way to reduce the complexity of these issues would be to gradually decrease the provision of ODA to zero over an extended period, allowing observation to determine if the country is ready or not. Indeed, the current blend period, during which a country gets both concessional IDA financing as well as non-concessional IBRD financing, was supposed to smooth this transition. However, as was shown earlier, IDA's financing in Vietnam peaked less than three years before its graduation from IDA, which didn't leave enough time for a gradual transition from a high level of concessional finance before its exit.

In any case, indicators are needed to assess if the gradual reduction and ultimate termination of ODA is harming future progress. USAID's new metrics-driven approach of using 17 third-party indicators has the potential to provide a thorough assessment of a country's readiness. ${ }^{48}$ 


\subsection{IDA'S CURRENT CRITERIA AND STAGES}

The current criteria used to determine graduation from IDA focus on the gross national income (GNI) per capita and a country's creditworthiness (see Box 1). Graduation from IDA is not an immediate decision. Figure 22 illustrates IDA's graduation process, which has two intermediate steps before the final graduation from IDA. An "IDA-only country" becomes a "gap country" if its GNI per capita has been above the cutoff point for more than two consecutive years. The cutoff point is determined annually and in FY2018 required having a GNI per capita of less than $\$ 1,165$ to be an IDA-only country. Once declared to be creditworthy by the IBRD, the gap country becomes a "blend country," and then finally graduates from IDA after an internal IDA review, though that process is currently far from transparent.

\section{Figure 22: IDA stages}

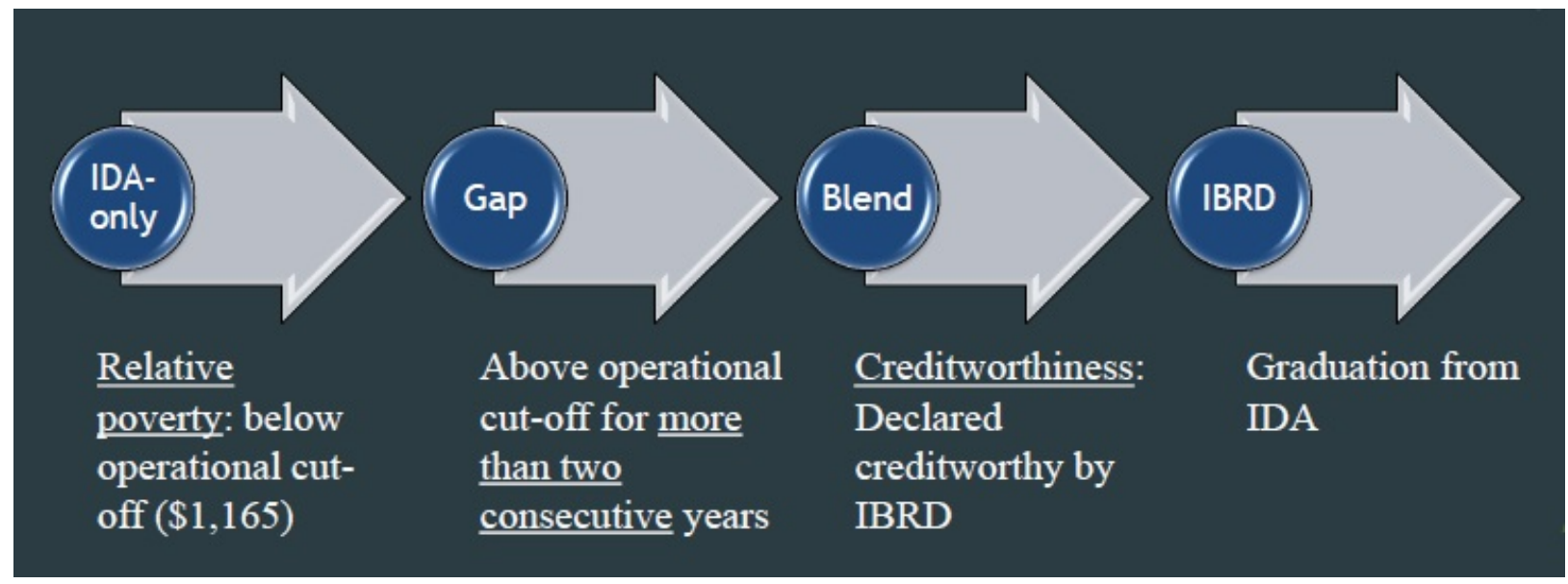

Source: Eigen-Zucchi, Christian (2017). In Support of Bangladesh's Sustainable LDC Graduation, Presentation made at the High Level Meeting of the United Nations Office of the High Representative for the Least Developed Countries, Landlocked Developing Countries and Small Island Developing States on "Achieving Sustainable Graduation for Least Developed Countries", Dhaka, Bangladesh, November 29, 2017, Slide 9. Available at: http://unohrlls.org/custom-content/uploads/2017/12/Christian-Eigen-Zucchi-The-World-Bank.pdf 


\section{Box 1: IDA's eligibility criteria}

Eligibility for IDA support depends first and foremost on a country's relative poverty, defined as GNI per capita below an established threshold that is updated annually ( $\$ 1,165$ in FY2018). IDA also supports some countries, including several small island economies, that are above the operational cutoff but lack the creditworthiness needed to borrow from the IBRD. Some countries, such as Nigeria and Pakistan, are IDA-eligible based on per capita income levels and are also creditworthy, so able to borrow from the IBRD. They are referred to as "blend" countries. As of May 2018, there were 75 countries eligible to receive IDA resources, 59 were IDA-only countries and 16 were blend countries. In some cases, countries that have graduated from IDA (like Vietnam) may receive what is called "transitional non-concessional funding" from IDA at IBRD-like terms, which is, however, not part of the blend country category as these countries have fully graduated from IDA.

Financing terms for IDA-only countries are linked to each country's risk of debt distress, with IDA providing grants to those with a high risk of distress, a mixture of grants and credits to those at moderate risk, and highly concessional credits to those at low risk. Recognizing their unique vulnerabilities, the most concessional IDA lending terms for small-island states were proposed to be available to all IDA-eligible small states in IDA18. For countries that have been above a certain income threshold (the operational cutoff) for more than two years, grant financing is no longer available, and the financing is on slightly harder, but still concessional, "blend terms." These blend terms are also available to those blend countries that have access to both IDA and IBRD support.

In some cases (including Vietnam), recent IDA graduates have received what is called "exceptional transitional IDA funding" after graduating from IDA (i.e., after no longer being blend countries). However, it is important to recognize that even though the funding is coming from the IDA pot in these cases, it is being provided on non-concessional (IBRD-like terms), so the countries do not continue to benefit from the concessionality offered to IDA countries.

Source: Based on information of IDA's website: http://ida.worldbank.org/about/borrowing-countries, and World Bank Group (2016), The IDA18 Replenishment (November), p. 3.

While IDA's GNI per capita criterion is simple, it is also unsatisfactory, as average GNI says very little about poverty in a country due to it not taking inequality into account. Only if there is no inequality would average GNI per capita be a useful indicator for poverty. Lea and Dercon (2016) have suggested replacing the GNI per capita indicator with a poverty gap indicator, ${ }^{49}$ which would be objectively much better as they account for not only poverty rates but also the depth of poverty (i.e., how far on average the poor are from the poverty line). The Human Development Index (HDI) and Inequality-adjusted HDI (IHDI) would also be far better indicators for IDA to use, shifting the focus of development from national income to people-centered policies.

Previous research by Oxfam (2016) shows the persistent need for external assistance in MICs, which are still home to the majority of the world's poor:

Poverty in these countries [MICs] is compounded by high levels of inequality. The poorest people in these countries have not yet been able to secure the resources, opportunities, or public investments to escape poverty and claim their rights. In addition to being home to some of the poorest people, many of these middle-income countries, and in particular those who have just joined this group, face a number of adverse shocks, such as slower growth or governance challenges. Some of them also host large groups of refugees and migrants, putting an additional strain on public budgets and increasing fragility. Donors should be very cautious about pulling out from these countries too fast or without due consideration simply 
because per capita income has risen, meaning a country has achieved middle-income status, when this actually has no relevance to poverty in that country.

While these countries are to a lesser degree dependent on aid than the least developed countries, aid still plays a vital role in these countries to strengthen the citizen-state compact. In doing so, aid is a critical tool for strengthening civic engagement so that people can claim their rights and their share of the benefits of national economic growth. Aid will thus also be needed to support people in these lower-middle-income countries to demand their share of development progress. ${ }^{50}$

Oxfam's suggestions are consistent with conclusions by development economists Ravi Kanbur and Andy Sumner (2012), who asked if aid should go to poor countries or poor people. They came to the conclusion that:

The new geography of global poverty throws into sharp relief development assistance policy towards MICs. A policy of sharply reducing, or entirely stopping, development assistance to MICs needs to be examined closely when the bulk of the world's poor live in these countries. Our discussion shows that there is no justification for a blanket exclusion of MICs from development assistance. Rather, we argue that the policy has to be crafted on a country specific basis, taking into account the detailed nature of poverty in each MIC, and the specific institutional and implementation context of development assistance. ${ }^{51}$

In order to capture a different piece of the story, we contrasted Vietnam's GDP per capita with its wealth per capita, as per the World Bank's new method for capturing the "wealth of nations." Though Vietnam has a comparable GDP per capita to Bolivia and Sri Lanka, Vietnam's wealth per capita in 2014 was $\$ 27,368$, just over half of Bolivia's $(\$ 49,235)$ and slightly less than two-thirds of Sri Lanka's $(\$ 44,970)$. Vietnam's lower wealth per capita is due to its lower human capital.," which is how the World Bank recently began referring to the combination of health and education outcomes in a given country, and which it began to include in its measurement of a nation's "wealth." 52 In addition, there are other important elements not captured, including climate-related and environmental risks. ${ }^{53}$

Despite the evidence that income per capita is a poor indicator to determine aid allocation and aid graduation, IDA's own assessment in March 2016 was that "IDA's flexible and holistic graduation process has helped countries make a successful and lasting exit from IDA. IDA's graduation process is comprehensive and relies on a careful case-by-case analysis of relevant country-specific factors in addition to its GNI per capita and creditworthiness criteria."

Given the extensive critique of IDA's GNI per capita criterion, IDA also stressed that "IDA's operational GNI per capita cutoff is set at an appropriate level and there is no pressing case for modifying it." IDA's own analysis comes to the conclusion that "modifying the GNI cutoff would not alter decisions on graduation, as they are based on creditworthiness and broader country-specific considerations in addition to the GNI cutoff. In fact, a higher GNI cutoff could have an unintended impact on IDA's finances by delaying countries being classified as gap countries, where IDA lends at blend terms." Finally, IDA justifies the use of the GNI per capita indicator by concluding that "indicators additional to GNI per capita are highly correlated with it, not as comprehensive, and not universally available." 54

The only concession IDA (2016) made was that it recommended "a more coordinated approach within and outside the World Bank to smooth transition to non-concessional finance for IDA graduates." IDA's review also notes that while there is a "systematic engagement by the Graduation Task Force with the country teams" within the World Bank, "it could come earlier in the process (when the country becomes blend) to ensure that the authorities are prepared for transition. 
Coordination with other multilateral and bilateral development partners could be further strengthened using existing mechanisms." 55

\section{Box 2: A gradual transition away from IDA}

The World Bank has presented in discussions that deciding a country is ready to graduate is not a simple formula, and confirmed that it assesses a variety of factors when considering IDA graduation, not just GNI per capita. Indeed one document mentions that during the transition from IDA to IBRD status, including through the stages of blended status, actual readiness to graduate to IBRD-only status is based on an assessment of a country's macroeconomic prospects, risk of debt distress, vulnerability to shocks, external debt and liquidity, political stability, levels of poverty, and social indicators. ${ }^{56}$ Despite this, the weight of each of these criteria and the assessment protocols do not appear to be publicly available. It is also important to note that some of the constraints on Vietnam's ability to access additional development resources are a result of the Vietnam government's own policy and planning processes. For example, the country's legal limit on public debt-to-GDP ratio severely constrains the government's ability to borrow. In addition, in the case of Vietnam there are several points to consider with respect to its continued access to various types of financing from the World Bank:

- Countries that graduated at the end of IDA17 are entitled to transitional support from IDA (on IBRD, non-concessional terms) for three additional years;

- The FY2018 IBRD capital increase package includes a commitment to replace 100 percent of IDA financing for IDA graduates on IBRD terms;

- Vietnam will continue to access the disbursements for not yet accessed IDA commitments made in previous years;

- Should any of the approved IDA projects be cancelled during the first six years after graduation, there is a possibility of committing the cancelled IDA resources to other projects on IDA blend terms.

While these recent policies have been introduced to ensure countries do not face an immediate lack of access to finance options once they graduate, the don't solve issues related to availability of finance at concessional rates.

\subsection{LESSONS FROM PREVIOUS IDA GRADUATIONS}

Since IDA was established in 1960, a total of 44 countries have graduated from IDA. However, nine of these 44 graduates (around 20 percent) have since re-entered IDA ${ }^{57}$ indicating the possibility that IDA graduation can happen prematurely. In some cases, the re-entry point was decades after graduation. For example, both Nigeria and Côte d'Ivoire re-entered IDA following political turmoil and violence that undermined development. Nigeria graduated from IDA in FY1965 and re-entered IDA more than 20 years later in FY1989. Similarly, Côte d'Ivoire graduated from IDA in FY1973 and re-entered IDA in FY1992. Both Nigeria and Côte d'Ivoire are currently still eligible to receive IDA resources as blend countries. No date has been set for the graduation of these two countries from IDA.

Azerbaijan graduated from IDA at the end of IDA15 (i.e., on June 30, 2011). Angola, Armenia, Bosnia \& Herzegovina, Georgia, and India graduated at the end of IDA16 (June 30, 2014). And as was already mentioned, Bolivia, Sri Lanka, and Vietnam graduated at the end of IDA17 (June 30, 
2017). The World Bank states that these three countries (Bolivia, Sri Lanka, and Vietnam) will receive transitional support on an exceptional basis through the IDA18 period (FY2018-FY2020). ${ }^{58}$ This transitional support will be provided at non-concessional (IBRD-like) terms. ${ }^{59}$

As stated by Kharas et al. (2014), p. 25: "Countries that graduated from IDA to less concessional World Bank terms (IBRD) hitherto did so relatively abruptly, and this move typically triggered a deeper overall reduction in the volume of external finance. But it usually takes much longer for such graduates to achieve substantial and reliable financial market access, or to develop their own domestic tax base. Meanwhile, these less concessional public windows may not meet the graduate's needs in either volume and/or other terms."

Last but not least, the UN Economic and Social Council (ECOSOC)'s Financing for Development Follow-up in April 2018 acknowledged that "ODA and other concessional finance are still important for a number of middle-income countries." $" 0$ It would therefore be a mistake for the World Bank and its IDA donors not to make at least some improvements to IDA's graduation process. Even though these changes may come too late for Vietnam, they may be even more important for the next cohort of IDA graduates. ${ }^{61}$

One useful reference point for Vietnam and other countries graduating from IDA is the experience of Indonesia, which has been examined in detail by Prizzon et al. (2017). ${ }^{62}$ Indonesia initially graduated from IDA in 1980, re-entered in 1999 after the Asian financial crisis, and then regraduated in 2009. Prizzon et al. (2017) focuses on how the Government of Indonesia has managed the transition from concessional to less-concessional finance. The analysis of the development finance landscape in Indonesia reveals that there have been some significant changes in the relationship with bilateral donors and multilateral donors.

Furthermore, as was analyzed in more detail in Greenhill et al. (2013), 63 the shift from grants to concessional and then non-concessional loans can also alter the way in which aid is allocated among sectors. Given their potential returns and/or ability to generate cash flows, infrastructure projects, such as toll roads and utilities, tend to attract funding that is less concessional. No doubt, oil wealth also helped Indonesia in this transition. The social sectors, however, such as education and health, tend to be supported either by public taxation or grants rather than loans from donor governments.

Prizzon et al. (2017) show that the total amount of ODA fell when Indonesia graduated from IDA the second time in 2009. "The gap was filled, in part, by a rise in OOFs - official funding that does not meet ODA criteria. However, the importance of all official external sources as a share of total external financing, and of GDP and government revenues, has declined sharply since 2000 . The financial impact of 'less concessional' loan terms since 2009 has also been considerably dampened by a long period of exceptionally low global market interest rates - a window which, from early 2017, may be starting to close." Further lessons from Indonesia's IDA graduation are provided in Box 3. 
Box 3: Lessons from Indonesia's IDA graduation (Prizzon et al. 2017)

Adapt flexibly to changing supply terms - which are largely decided unilaterally by the external official finance community - rather than trying to design and implement a deliberate strategy to exit from aid. Indonesia's pragmatism extends to its continued openness to policy advice from external agencies, including those (such as the World Bank) that have long been the focus of political resistance to foreign intrusion.

Practice sophisticated debt management - The tension between rising demand for growthoriented investment and the need for sustained debt discipline must be well managed. Indonesia's debt management and investment planning have been central to its economic policy for some time, becoming increasingly sophisticated. Statutory caps on the central government deficit and overall debt have also imposed political discipline, especially since current revenues have stagnated. However, a note of caution that is not unique to Indonesia must be applied to government encouragement of off-budget financing, particularly direct international borrowing by state-owned enterprises (SOEs) with implicit state guarantees. This tactic circumvents fiscal and debt ceilings in the short term but may pose contingent risks for the future. These need to be monitored effectively.

'Bundle' external finance with support for capacity building - regardless of the financial terms of loans and the speed of loan processing, which may favor some sources over others. Indonesian ministry officials were concerned about poor delivery by some government departments, local administrations, and SOEs. They were particularly concerned about poor project selection, slow downstream execution, and non-competitive pricing, which could wipe out any advantage gained from cheaper loans and/or faster processing. They appreciated the greater support offered by the MDBs and some bilateral donors for project design, feasibility assessment, and monitoring. They also saw technical assistance on cross-cutting issues such as public financial management, decentralization, etc. (even if not directly linked to largescale financial support) - as underpinning it indirectly.

Prioritize mobilization of domestic tax revenue - The transition to lower dependence on foreign aid flows may become riskier if public revenues, particularly tax revenues, fail to grow. As noted, Indonesia exemplifies the "missing middle" conundrum, and the looming 3 percent deficit ceiling piles on the political pressure and uncertainty (e.g., leading to sudden postponement of major investment projects), and leads to creative off-budget financing that can store up problems for the future. An expanded menu of international financing options, however useful, does not overcome the need to mobilize greater domestic tax revenues.

Source: Prizzon et al. (2017), Executive Summary, p. 8.

Some other general lessons from previous aid transitions have been captured by Rose et al. (2017) in the form of strategic recommendations for USAID. ${ }^{64}$ Their first lesson is that USAID should define transition goals, while recognizing US foreign policy objectives. Their second lesson is that USAID should consider options short of complete aid exit. They suggest that phasing out assistance in certain sectors may be an alternative to full exit. Third, they suggest that USAID should recognize that coordination between a number of actors is crucial for effective transition planning, including coordination with other US agencies, various actors in the recipient country, and other donors.

Their fourth lesson, which suggests USAID should assess and mitigate risks to sustain development results, is likely the most important, building on the fact that bilateral donors often pay insufficient attention to the host country's development needs during a transition. "Phasing out grant funding for services and other development programs carries the risk that development gains will be lost," state Rose et al. Hence, "USAID should ensure that one of the goals of transition is protecting the value of its past investments by sustaining and even building upon achieved results. To do so, 
USAID should (a) identify options for priority areas to be advanced by others, whether local entities (public or private) or other donors, and (b) consider how to employ remaining grant funding to prepare the designated actors to take on new managerial roles and/or financial obligations" (p. 14).

Additionally, Rose et al. refer to a review of the UK's aid exits from China, India, Vietnam, and Cambodia, which found that "DFID's former civil society partners had to scale back their activities and felt the loss of the United Kingdom's role in brokering arrangements, generating access, and protecting against actions intended to narrow space for civil society to engage in development issues." In most cases, DFID failed to carry out institutional assessments to identify capacitybuilding needs that would enable the partner country institutions to deal with the transition from aid.

These lessons point to the importance of maintaining relationships before, during, and after exit, with transparent communications with the host country government, civil society organizations, and the media. Whether IDA graduation or a strategic re-alignment of an ODA donor, it is crucial to focus transitional aid on capacity building and ensuring past investments are secured. This is especially true for protecting gains of civil society, movements for gender equality, and other domestic actors who may be left in a vulnerable position. For governments, some of the biggest contributions that exiting donors can make include technical support for boosting DRM and sophisticated debt management tools. 


\section{RECOMMENDATIONS}

\subsection{RECOMMENDATIONS FOCUSING ON VIETNAM}

The first key recommendation is that, despite IDA graduation, Vietnam should continue to receive other sources of ODA focused on improving social development, institutional strengthening, and DRM. This recommendation is, however, not intended to advise a continuation of ODA in its current form. Rather, Oxfam recommends that Vietnam receives ODA that has the appropriate mix of concessional and non-concessional financing, determined through careful analysis, while providing concessional finance towards the programs and policies which most strongly fight poverty, inequality, and gender inequality. A further withdrawal of ODA from Vietnam could have harmful effects for Vietnam's future development. This recommendation is based on a variety of facts:

- First, net ODA flows to Vietnam increased from $\$ 0.18$ billion in 1990 to an all-time high of $\$ 4.23$ billion in 2014, after which it started to decline drastically, reaching $\$ 2.89$ billion in 2016 (see Figure 2). Even though net ODA to Vietnam is now small as a percentage of GDP, 1.41 percent in 2016 and estimated to be 1.35 percent in 2019 (as shown in Figure 3), there is broad agreement that Vietnam's achievements in social development have been fueled by aid but that huge insufficiencies and inequalities remain.

- Second, our analysis has shown that even though Vietnam's government now has some ways to raise non-ODA development finance, there is very limited space to increase or maintain Vietnam's relatively high revenue-to-GDP ratio. Most medium-term projections actually show a decline in revenue/GDP. ${ }^{65}$ And raising development finance either via non-concessional external borrowing or domestic borrowing will severely threaten Vietnam's fiscal debt sustainability (even though external debt sustainability is far from being threatened due to Vietnam's huge export market value). Debt service on public debt cannot, however, be paid by exports but by government revenues. Hence, the usual focus on Vietnam's external debt sustainability is heavily misguiding, as it doesn't account for Vietnam's capacity to pay for sharply increasing debt service payments, including on existing concessional loans.

The second key recommendation is that the GoV needs to be more flexible in enabling ODA to go directly to local initiatives and CSOs that have a proven track record. While there is still a role for ODA to be provided to the government, there are more and more grassroots-based initiatives that are better equipped to provide people-centered development initiatives and support citizen-led accountability efforts that would improve the provision of social services. Given that nearly all gender equity projects in Vietnam have been supported by ODA, exit strategies have to ensure that these projects will be continued and future ones supported.

Third, while there are compelling arguments for the Vietnamese government to have a clear, stateled ODA approach to prioritize the government's identified development needs, the effectiveness of ODA will be enhanced by the involvement of decentralized actors (or in Vietnamese terms, "socialization"), including both state and non-state recipients, helping ensure aid reaches people and communities that still have high levels of poverty.

Fourth, there is a wide range of complementary development finance, which, if effectively tapped, will help Vietnam achieve the SDGs without threatening its fiscal debt sustainability. These resources include foreign direct investments (FDIs), portfolio equity investments (PIs), remittances, sovereign wealth funds, diaspora bonds, and domestic resources held by individuals (e.g., gold). 
Not all of these resources are fully exploited at this time. Governments do, however, need to manage risks and avoid unexpected costs associated with these types of financial flows, as highlighted by recent cases of public-private partnerships. ${ }^{66}$ In order to ensure public resources remain intact to address the policy and sectoral demands of the SDGs, DRM will have to keep pace.

Fifth, given that the international financial system is prone to crisis, Vietnam needs to be more proactive in shaping and implementing crisis prevention strategies at both the regional and international level, ensuring that a temporary financial imbalance does not create a panic. This will become more and more important for Vietnam as it becomes more integrated into the world financial system and consequently becomes more vulnerable to such crises.

Last but not least, though not discussed in detail in this report, given that Vietnam is one of five coastal developing countries most affected by climate change, it needs to increase its efforts to mainstream its climate change response within sectoral and provincial programs, mobilize resources for climate change response activities, promote understanding climate change in the mass media and education system, and invest in the necessary human resources and technical skills to combat the effects of climate change, which typically impact the poorest and most vulnerable the most. ${ }^{67}$

\subsection{RECOMMENDATIONS FOR THE GLOBAL AID SYSTEM}

First, IDA should adjust its graduation indicators, reflecting the indicators and data available today. The GNI per capita indicator was useful in the $20^{\text {th }}$ century, but it is overdue to be replaced by a combination of poverty measures and social indicators. At a minimum, the income per capita criterion should be replaced with the IHDI, which has been reported annually for almost every country in the world since 2010 . These changes should be made and communicated transparently.

Second, the rich countries that do not yet provide 0.7 percent of their GNI as aid need to make good on the promise that has been made repeatedly since it was originally adopted as a UN Resolution in 1970. This would increase the funding for IDA and hence reduce the pressure for countries to graduate from IDA prematurely.

Third, given that the world's leaders adopted Agenda 2030 on September 25, 2015, development partners should affirm that meeting the SDGs is the operational objective for the allocation of aid, with country-level poverty reduction strategies at the heart of development support based on a combination of needs and aid effectiveness criteria. There is also room to better coordinate ODA exit strategies across donors so that valuable technical and financial support via non-IDA ODA continues in an appropriate way after IDA graduation. IDA graduation should not be linked (even informally) to automatic withdrawal of other ODA resources. In fact, this aid becomes more important once IDA resources are no longer available. Beyond coordinating exit strategies, donors should work on synchronizing transition indicators and processes.

Fourth, the recent focus on private sector involvement, even using ODA to bring in the private sector, cannot distract from the need to use ODA for priority public investments in the social sectors to achieve the SDGs, This especially critical where private sector involvement in the social sector is either impossible or has negative impacts on poverty and inequality, for example by introducing service fees the poor cannot afford. While involving the private sector in development makes sense, as there are insufficient funds to finance all the needed investments to achieve the SDGs with 
public resources, this push adds complications considering that private and public resources are not interchangeable.

Fifth, support for greater public DRM is key and should be prioritized, but this takes time, and cannot be seen to be an immediate alternative. It will take multiple IDA cycles for countries to mobilize their domestic resources to the degree that they would replace concessional funding.

Sixth, the dependency on ODA differs across sectors, and hence reduced ODA needs to be prioritized to sectors that are the most vulnerable to a decline in aid and that cannot be effectively replaced by private sector financing. The World Bank and other donors should target concessional funds to the types of programs and policies with a strong focus on fighting inequality and promoting inclusive development. These include universal, high-quality, free public education and healthcare; progressive taxation; strong decent work conditions; and support for capacity building in public goods management, such as agriculture, and other social programs that focus on reducing poverty and inequality, especially gender inequality.

Seventh, ODA should focus more on capacity building and institutional strengthening for the delivery of social services, including via CSOs and working with CSOs to influence policies and delivery of social services. To increase the effectiveness of scarce resources, ODA should be a catalyst rather than the main direct source of funding for services and infrastructure.

Finally, both IDA graduation and ODA withdrawal should be more gradual processes than they are currently, with a mix of concessional and non-concessional finance during an extended transition period. Over this period, the terms of lending should harden gradually, with a steady linear decline in access to ODA (instead of ODA peaking shortly before IDA graduation, as was the case in Vietnam). ${ }^{68}$ Because LMICs often have large numbers of people living in poverty and high levels of inequality, a careful analysis of the appropriate mix of concessional and non-concessional financing is needed. 


\section{ANNEX I: SNAPSHOT OF VIETNAM'S RECENT DEVELOPMENT}

The Đổi Mới (Renewal) reforms, which began in 1986, have led to significant economic policy changes in Vietnam. Private enterprise has developed, along with increasing direct investment from foreign companies. Vietnam has become more integrated into the regional and global economy, including becoming a member of the Association of Southeast Asian Nations (ASEAN) and the World Trade Organization (WTO). There is broad agreement that Vietnam would have benefited overall from the now-suspended Trans-Pacific Partnership, though some sectors such as agriculture would have faced strong competition. However, Kikuchi, Yanagida and Vo $(2018)^{69}$ have stressed that Vietnam will still benefit from other promising regional frameworks, including the recent EU-Vietnam Free Trade Agreement.

Vietnam has experienced rapid economic growth in the last 30 years (averaging 6.4 percent a year from 1985-2016), characterized by rising average incomes and a steady and significant fall in the number of people who are living in poverty. Indeed, from 1992 to 2016 more than 30 million people were lifted out of extreme poverty in Vietnam, defined as living below $\$ 1.90$ a day (2011 PPP). ${ }^{70}$ Vietnam's HDI also increased from 0.48 in 1990 to 0.68 in 2015. In terms of current US dollars, GDP per capita increased from $\$ 95$ in 1990 to $\$ 2,171$ in 2016 . Vietnam attained LMIC status in 2009 and achieved all of the MDGs, with the exception of environmental protection.

While the impact of this rapid growth on inequality in Vietnam has been more modest than in most other countries, as documented in Oxfam's (2017) Vietnam inequality report, economic inequality has been increasing in Vietnam. The challenge of eliminating poverty and achieving economic security (which is internationally defined as having a daily per capita consumption of at least a 2011 PPP of $\$ 5.50$ ) is significant. Despite the rapid poverty reduction Vietnam achieved between 2010 and 2016 (the average deduction in the number of people living below the $\$ 5.50$ poverty line was 21.3 percent every two years between 2010 and 2016), it will take until at least 2031 for the percentage of people living on less than $\$ 5.50$ (2011 PPP) to fall below 5 percent. ${ }^{71}$

As the analysis in this report shows, without continued concessional aid, it is unlikely that Vietnam will continue to grow at the same rate seen during the last few decades, and hence, this might threaten recent accomplishments in the reduction of poverty and further increase economic inequality and gender inequality. The next six sections of this Annex review Vietnam's recent developments in terms of (1) economic growth, (2) human development, (3) poverty reduction, (4) economic inequality, (5) gender equity, and (6) social mobility.

\section{A.I.1 RECENT DEVELOPMENTS IN TERMS OF ECONOMIC GROWTH}

As is well known, Vietnam has made huge progress in increasing its GDP per capita during the last few decades. If considering a fixed 2011 PPP, GDP per capita increased from $\$ 1,453$ in 1990 to $\$ 5,838$ in 2016 . These are close to world record achievements, and are underpinned by exceptionally high GDP growth rates. However, as Figure 23 shows, GDP growth and GDP per 
capita growth have been on a declining trend since the mid-1990s. While the average GDP growth rate during 1990-2016 was 6.4 percent per year, and the average GDP per capita growth rate was 5.4 percent during the same period, during 2011-2016 they dropped to 6 percent and 4.8 percent respectively. The medium-term projected GDP growth rate is between 6.2 and 6.5 percent.

Figure 23: Evolution of annual GDP growth and GDP per capita growth, 1990-2016

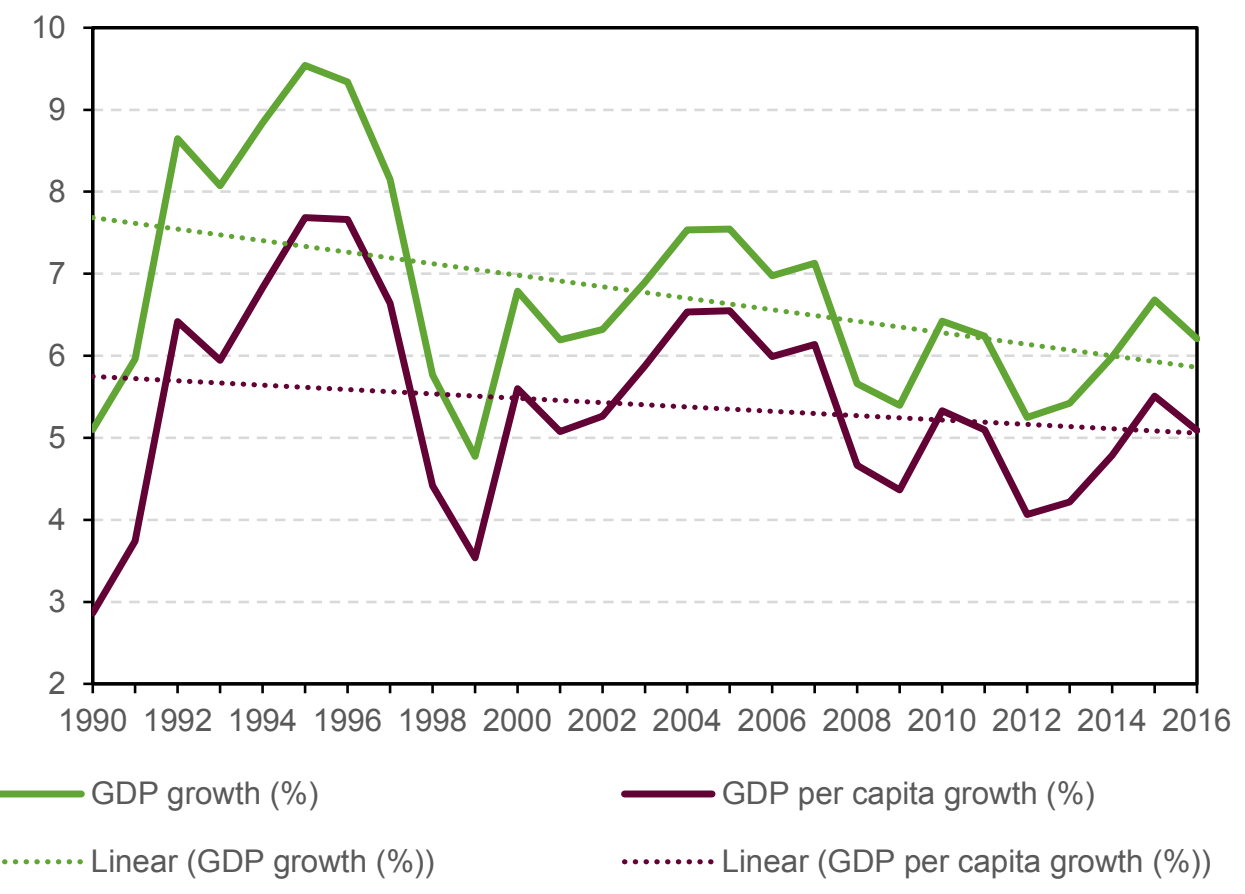

Source: Calculations based on World Bank (2018), WDI/IDS database.

Figure 24: Sources of Vietnam's GDP growth

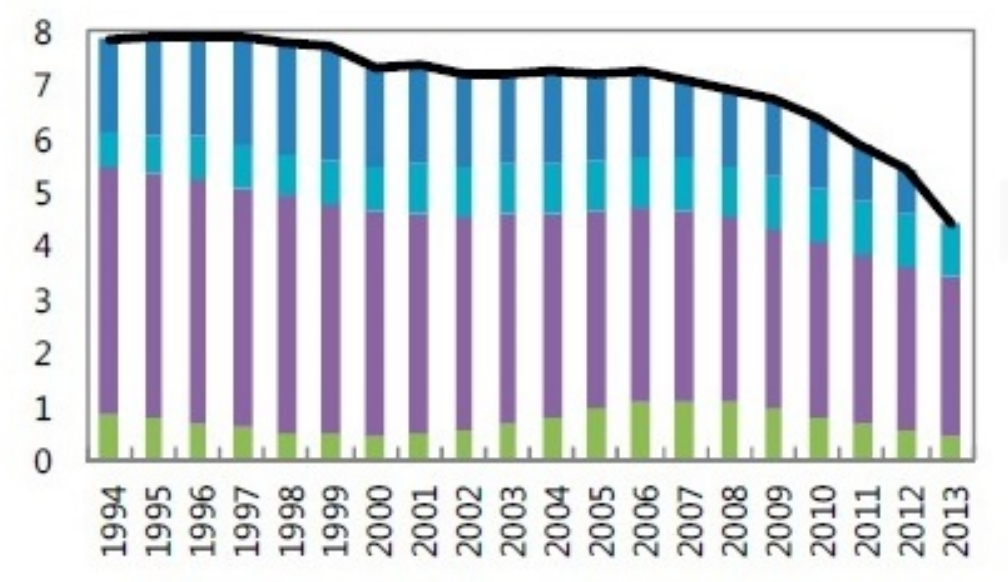

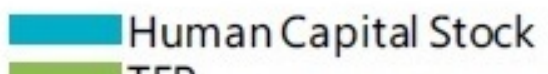

TFP 
As shown in Figure 24, the main source of Vietnam's economic growth over the last few decades has been physical capital accumulation. "The lackluster developments in Vietnam's trend growth may have reflected tighter macroeconomic stabilization policies amid heightened macroeconomic and financial risks as well as inefficiencies associated with the dominance of state-owned enterprises (SOEs)," according to Rahul Anand, et al. (2004). ${ }^{72}$

Building on Anand (2014), Kikuchi, Yanagida and Vo (2018) $)^{73}$ suggest that many sectors may shrink without continued strong capital accumulation, and they therefore suggest that it will be especially important to continue to invest in emerging high-tech manufacturing sectors. Furthermore, while Vietnam might be considered to have been successful in building basic infrastructure in the past, an ADB (2017) report indicates that this might not be the case in the future as the infrastructure needs of middle-income economies evolve. ${ }^{74}$ Furthermore, Vietnam's public debt-to-GDP ratio has been growing at an alarming rate, reaching $63.7 \%$ in 2016 . Limited fiscal space means that tax and administrative reforms are needed as well as greater reliance on public-private partnerships.

The GoV has also raised concerns about Vietnam's future growth rate, suggesting that it needs to address some of the underlying bottlenecks if it wants to achieve more sustainable and inclusive growth. To remove these bottlenecks, the GoV has identified the need to focus on "creating productive employment opportunities, strengthening policy incentives to develop supporting industries and intermediate technology, improving infrastructure and promoting R\&D and innovation." At the same time the education and vocational training systems need to be reformed to provide quality and relevant skills on an equitable basis. Equally, a more effective social protection system is needed to limit vulnerability, counter risk aversion, and to spur economic activity and entrepreneurship. ${ }^{75}$

In 2016, a joint report by UNDP and the Vietnam Academy of Social Sciences (VASS) ${ }^{76}$ found that Vietnam performed well on both human development and economic growth in the early and mid-Đổi Mói years, but that Vietnam's strong performance has waned in recent years, especially after the 2008 global financial crisis. Disparities between regions, provinces and population groups have not been closed. While past growth has brought significant social transformation, people living in poverty are harder to reach, particularly those within remote ethnic minority communities. Growth has also brought social risks and dislocations (as will be detailed in section 6 of this Annex).

According to UNDP and VASS, an inclusive growth strategy can close some of these gaps, advancing human development and providing opportunities for all. Three policy pillars ensure an inclusive growth approach: boosting productive employment opportunities, securing high-quality education and health care for all, and ensuring a high level of social protection coverage. Current government policies do not seem to be achieving these goals. In December 2017, the World Bank stated that "the decline in public investment, falling to 16 percent of total spending in the first nine months of 2017 compared with an average of 25 percent in recent years, may not be sustainable over time, as Vietnam needs significant investments in infrastructure to support future growth."77

Finally, given that Vietnam is one of the countries most vulnerable to climate change, its future growth rate is heavily dependent on the impacts of climate change. Climate change-related disasters, such as annual typhoons and ongoing salinization of the Mekong Delta, tend to reduce growth and could erode decades of progress. While addressing the impacts of climate change on the country's future growth rate, the Vietnamese government will also need to address the environmental risks resulting from its own pursuit of high growth rates as a goal rather than a means of development. ${ }^{78}$ While Vietnam's GDP may continue to grow at a high rate, the country 
faces serious social and environmental risks. The end of access to concessional financing and donor-supported technical assistance removes one important avenue to address these risks.

\section{A.I.2 RECENT DEVELOPMENTS IN TERMS OF HUMAN DEVELOPMENT}

As Figure 25 shows, in 1990, Vietnam had a lower HDI than Bolivia, and a far lower HDI than Sri Lanka. While Vietnam caught up with Bolivia in 2006 (partly due to Bolivia's HDI declining from 2005 to 2006), Vietnam's HDI is still considerably below that of Sri Lanka's. Given that all three countries currently have a similar GDP per capita, the differences in their HDI scores is due to differences in the other two indicators. Since Vietnam's life expectancy at birth (which was 80.9 years in 2016) surpasses that of Sri Lanka (78.6 years in 2016), ${ }^{79}$ Vietnam's lower HDI is due to a considerably lower score in the knowledge dimension of the HDI. ${ }^{80}$

Figure 25: Evolution of Vietnam's HDI compared with Bolivia's and Sri Lanka's, 1990-2015

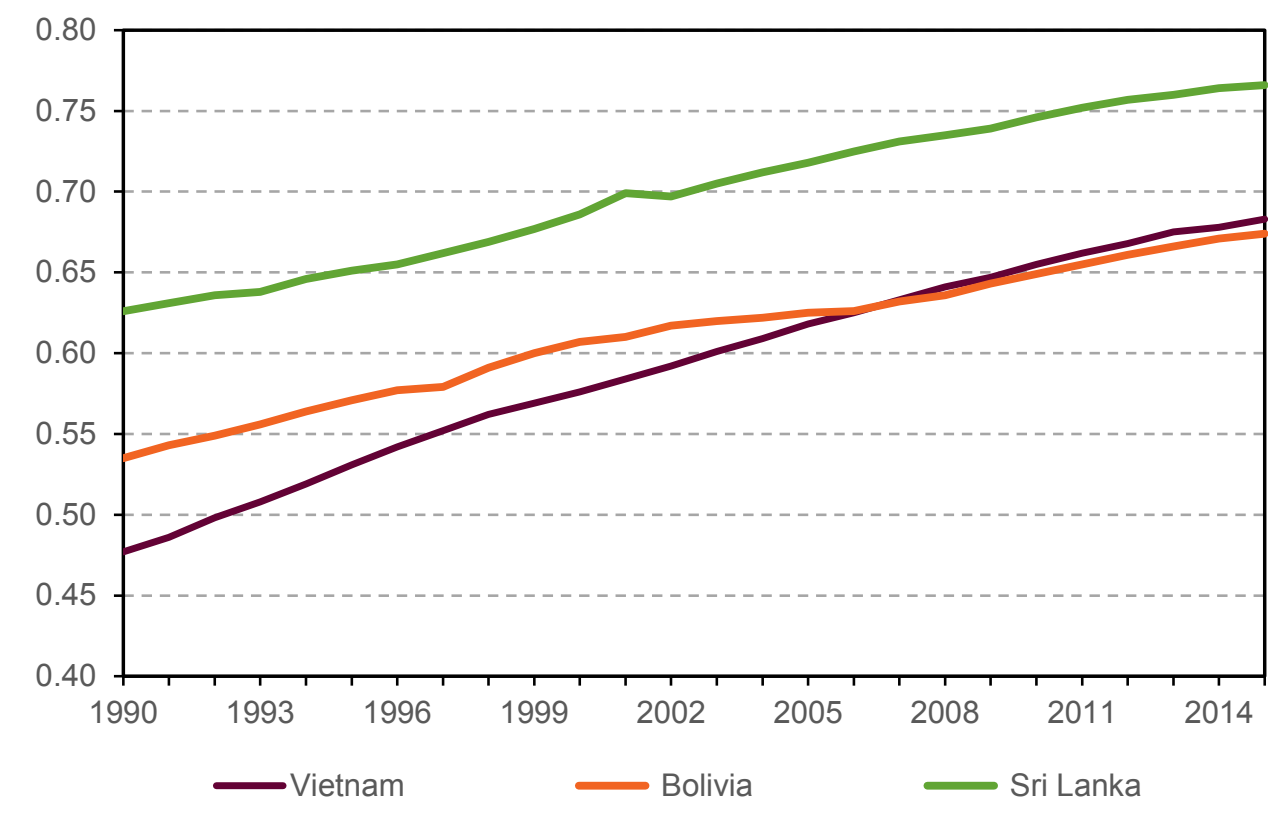

Source: Based on UNDP's Human Development Data website, downloaded June 5, 2018.

The next figure (Figure 26) shows that Vietnam's HDI increased rapidly from 1991 to 1998, but that it has slowed down considerably since. While Vietnam's HDI increased much faster than Bolivia's and Sri Lanka's during most of the 1990s, during the last few years their rates of growth have become similar. Yet, at these current rates, Vietnam and Bolivia will still not catch up with Sri Lanka. 
Figure 26: Increase of Vietnam's HDI (percent), 1991-2015

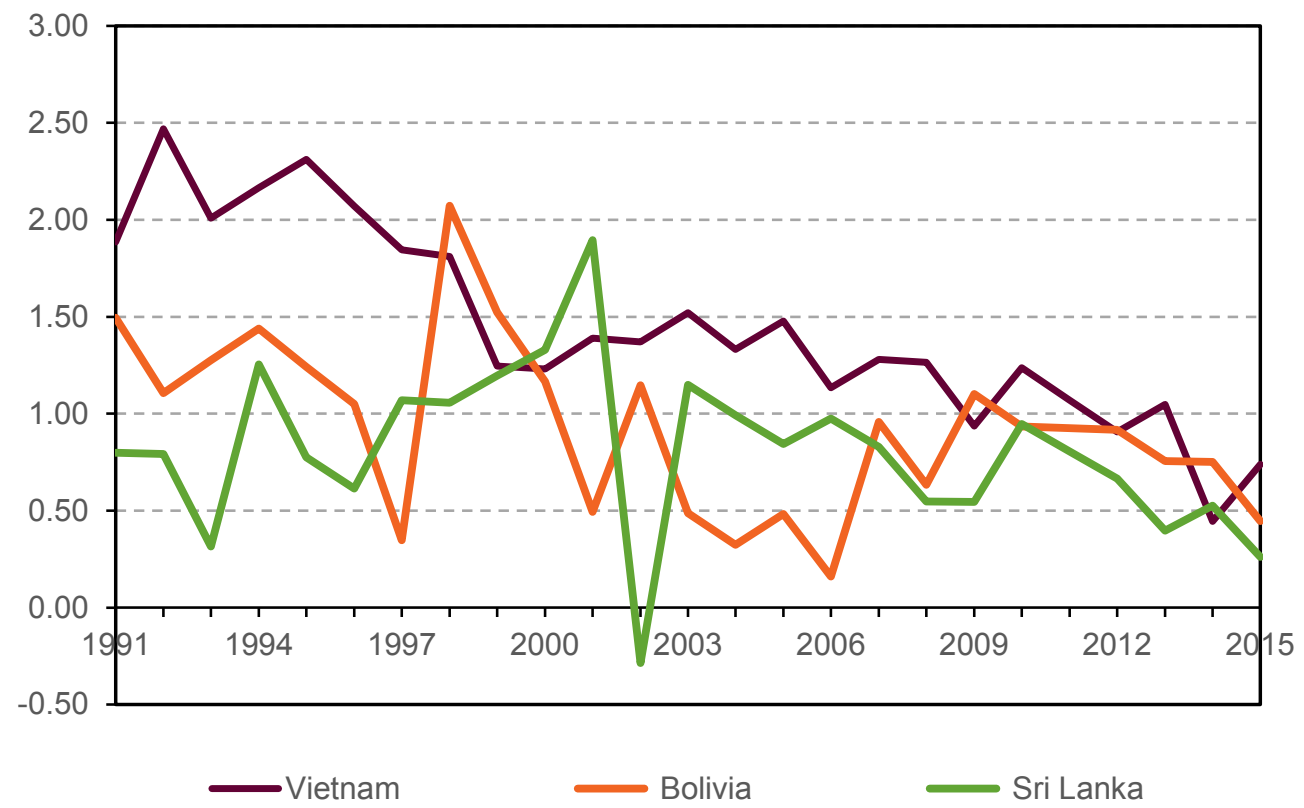

Source: Based on UNDP's Human Development Data website, downloaded June 5, 2018.

\section{A.I.3 RECENT DEVELOPMENTS IN TERMS OF POVERTY REDUCTION}

Figure 27 shows the evolution of all available data for alternative headcount measures of poverty. It includes the three international poverty measures at $\$ 1.90$ a day, $\$ 3.20$ a day, and $\$ 5.50$ a day ${ }^{81}$ (all in 2011 PPP); and the national poverty line, which was 969,167 Vietnamese Dong (VND) per person per month in 2016, equivalent to $\$ 3.34$ per day in 2011 PPP. Based on the official data, there is no doubt that Vietnam has massively reduced its percentage of people living in poverty. 
Figure 27: Evolution of income poverty (all available years)

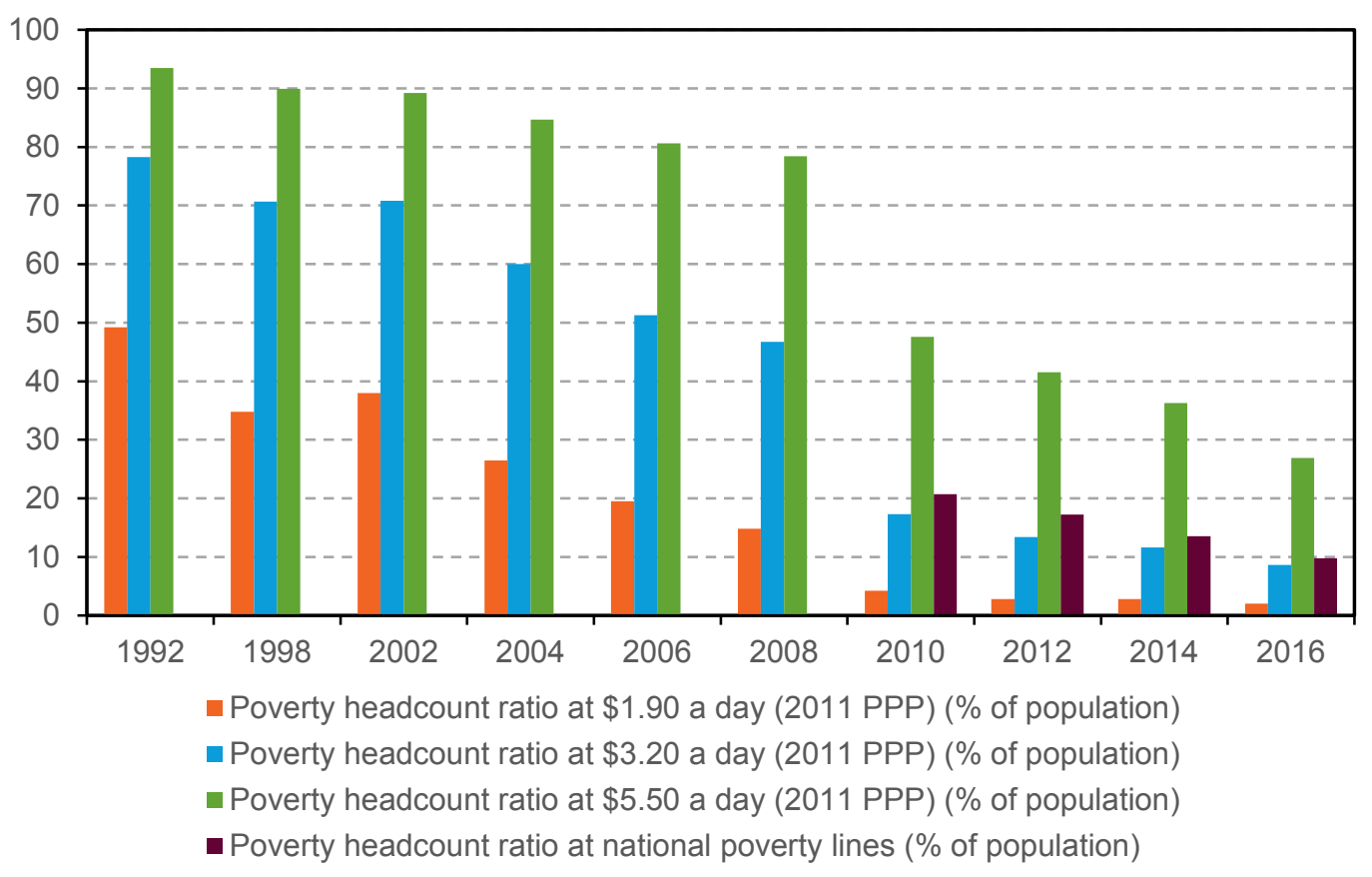

Source: For 1992 to 2014: World Bank (2018), WDI/IDS database (available online; downloaded on April 19, 2018); for 2016 data: World Bank (2018), Poverty Assessment.

When the differences in population size over time are taken into account, Figure 28 shows a slightly different picture. For the $\$ 1.90$ a day poverty measure, the number of Vietnamese people living in poverty decreased from 35 million in 1992 to 27.3 million in 1998, but then increased to 31.1 million in 2002 before declining continuously after that. For the $\$ 3.20$ a day poverty measure, the number of Vietnamese people living in poverty remained about the same in 1992 (55.7 million) and 1998 (55.5 million), though it then increased to 58 million in 2002, after which the number decreased continuously. Looking at the $\$ 5.50$ a day poverty measure, the number of people living in poverty has increased from 66.5 million people in 1992 to 70.5 million in 1998, reaching a maximum of 73.1 million people in 2002, after which it also decreased continuously. 
Figure 28: Evolution of income poverty (in terms of millions of people)

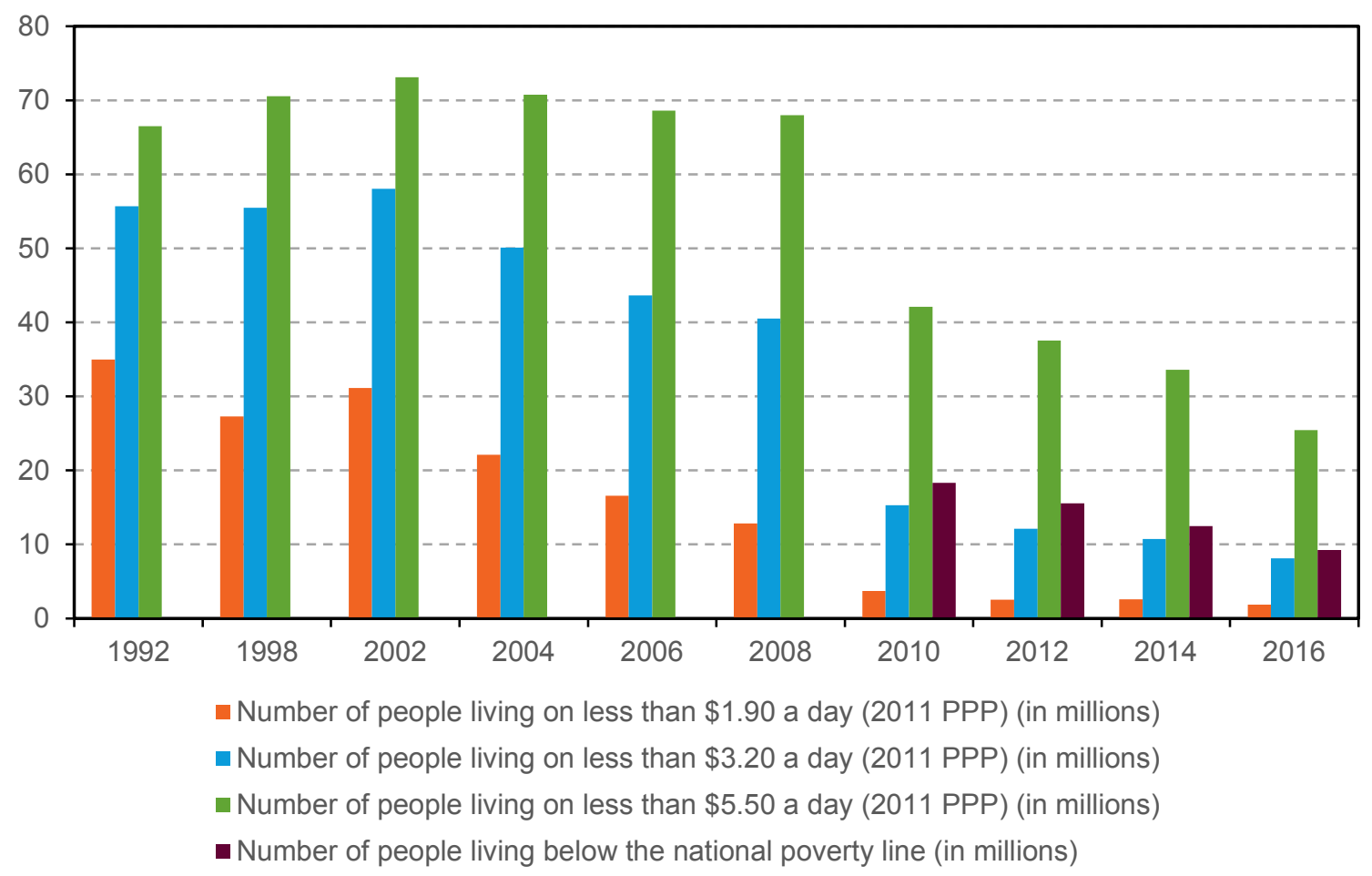

Source: Based on World Bank (2018), WDI/IDS database and World Bank (2018), Poverty Assessment.

As of 2016, 1.9 million Vietnamese lived below $\$ 1.90$ a day, 8.1 million Vietnamese lived below $\$ 3.20$ a day, 9.3 million Vietnamese lived below the national poverty line (which is equivalent to 2011 PPP $\$ 3.34$ a day), and 25.5 million Vietnamese lived below $\$ 5.50$ a day. From 2014 to 2016, poverty declined for all groups, both ethnic minorities and the majority. The poverty gap, which measures how far consumption of the poor is below the poverty line, has also steadily declined, indicating that poverty is becoming less severe among those still living in poverty. However, there is still about 30 percent of Vietnam's population that can be classified as economically insecure (which is defined as having a daily per capita consumption of less than 2011 PPP $\$ 5.50$. Only 13 percent of Vietnam's population have a daily per capita consumption of at least 2011 PPP \$15. Inequalities in opportunities entrench existing gaps between groups. While welfare has improved across the board, inequalities between groups are not closing fast enough. Close to 45 percent of ethnic minorities still live in poverty. Thus, ethnic minorities, who make up only 15 percent of the country's population, constituted 73 percent of the poor in $2016 .{ }^{82}$

The World Bank (2018) has concluded that Vietnam is far from being done with eliminating poverty and that there are various new challenges that need to be addressed. Labor productivity and skills are key to sustaining high-wage income growth. Adapting the social protection system to suit an export-oriented wage economy will be necessary. Strengthening land use rights and legal protections will further unlock the agricultural potential of those living in poverty or near poverty. Ensuring equal education opportunities is central to reducing both poverty and inequality. ${ }^{83}$ 


\section{A.I.4 RECENT DEVELOPMENTS IN TERMS OF ECONOMIC INEQUALITY}

Figure 29 shows the evolution of income inequality measured by the Gini Index and based on the World Bank's World Development Indicators (WDI) database of April 2018, supplemented by data provided in the World Bank's Vietnam 2018 Poverty Assessment. Based on this data, income inequality peaked in 2010, after which it decreased until 2014, and then rose again in 2016.

Figure 29: Evolution of income inequality (measured by Gini Index)

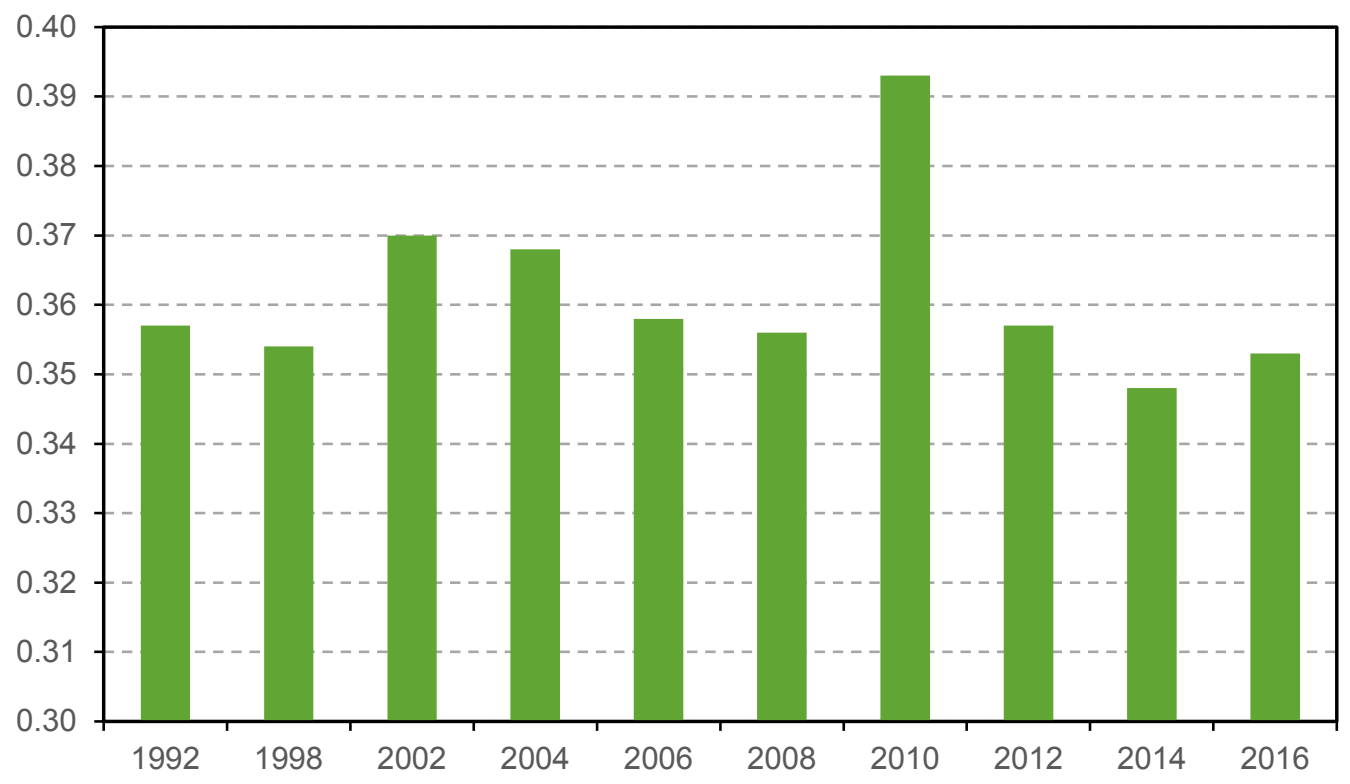

- Gini Index based on World Bank (2018), supplemented by 2018 Poverty Report

Note: A Gini of zero would imply that everybody has exactly the same income; a Gini of one would imply that one person has all the income, all others have no income.

Source: World Bank (2016, 2018), WDI/IDS database; and World Bank (2018), Poverty Report.

Another useful way to examine inequality is to look at the income shares of the poorest and richest deciles (only available until 2014). According to the latest official data, the income share held by the richest 10 percent of people in Vietnam has been relatively volatile (see Figure 30), first increasing from 1992 to 2002, then decreasing between 2002 to 2006, then raising sharply from 2008 to 2010 , just to decline even stronger in the subsequent four years. Overall, the share of the richest 10 percent fluctuated between a minimum of 26.8 percent (in 2014) and a maximum of 30.9 percent (in 2010). The income share of the poorest 10 percent has been less volatile but shows a downward trend. As of 2016, the poorest 10 percent had a share of 2.7 percent of Vietnam's total income. 
Figure 30: Evolution of income shares of top and bottom 10 percent, 1992-2014

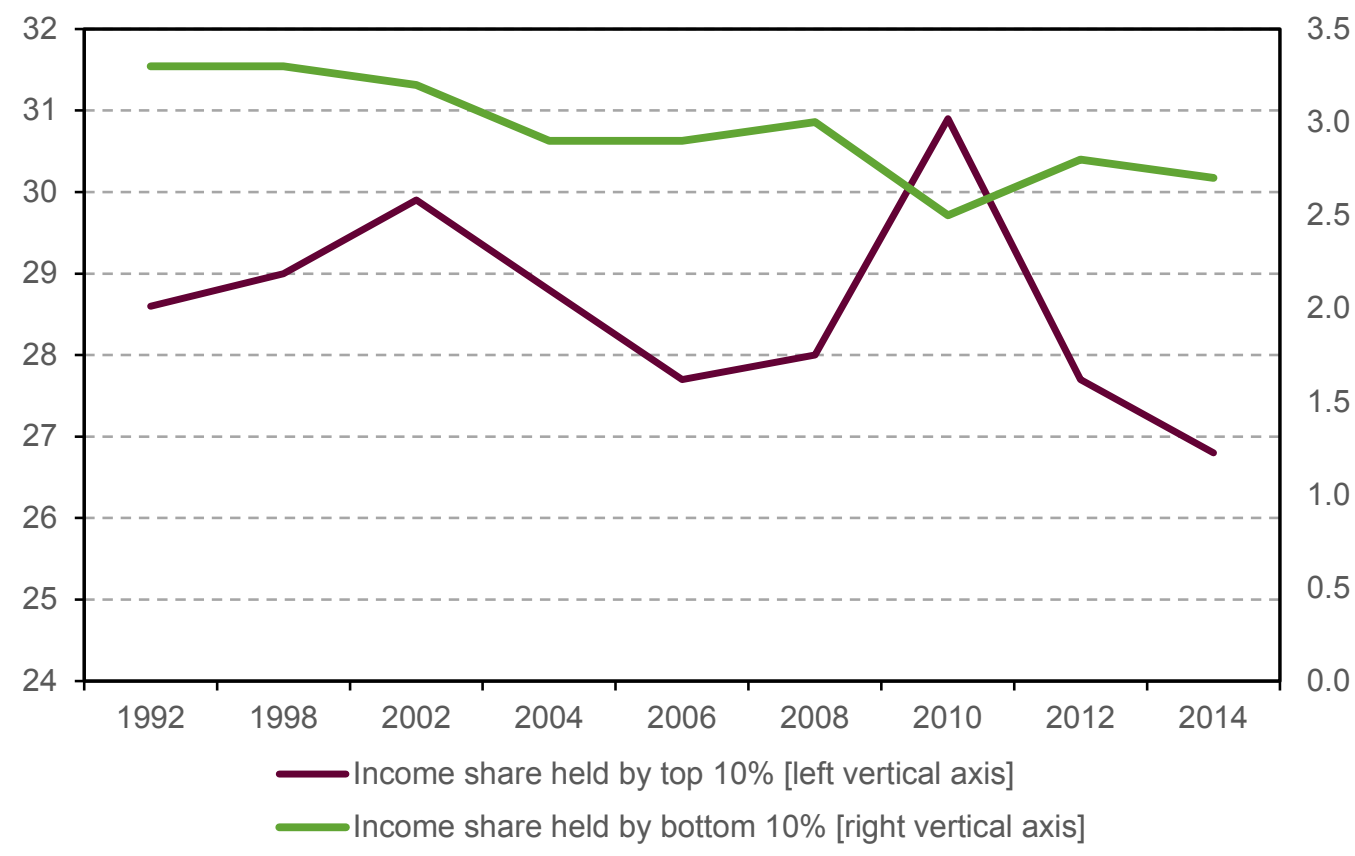

Source: World Bank (2018), WDI/IDS database.

Though not a formal measure of inequality, looking at the evolution of the wealth of the super-rich is another way to get an idea of wealth inequality in Vietnam. Knight Frank (which is a consultancy company in London that has issued Wealth Reports on an annual basis since 2007) reports how the number of super-rich people has changed over time for most countries in the world. One specific definition of a super-rich person is an ultra-high-net-worth individual (UHNWI), which is someone with a net worth of over $\$ 30$ million, excluding the value of their primary residence.

As Figure 31 shows, Vietnam had the highest growth rate in the number of UHNWIs from 2006 to 2016, and it is also expected to have the highest growth rate in the number of UHNWIs from 2016 to 2026. Though Vietnam's record growth rates of UHNWIs are partly explained by the very low number of UHNWIs they started with in 2006 (which was 48 persons, compared with 7,740 for Germany), the projection that Vietnam's number of super-rich people will increase from 200 in 2016 to 540 in 2016 is an indication that Knight Frank expects that inequality will increase massively during the next decade. A joint 2014 report by the United Nations Agencies in Vietnam, the Delegation of the European Union to Vietnam, and the Ministry of Planning and Investment of Vietnam stated: "As Vietnam's economic transition continues, it is inevitable that income inequality will continue to rise." 84 
Figure 31: Evolution of number of UHNWls

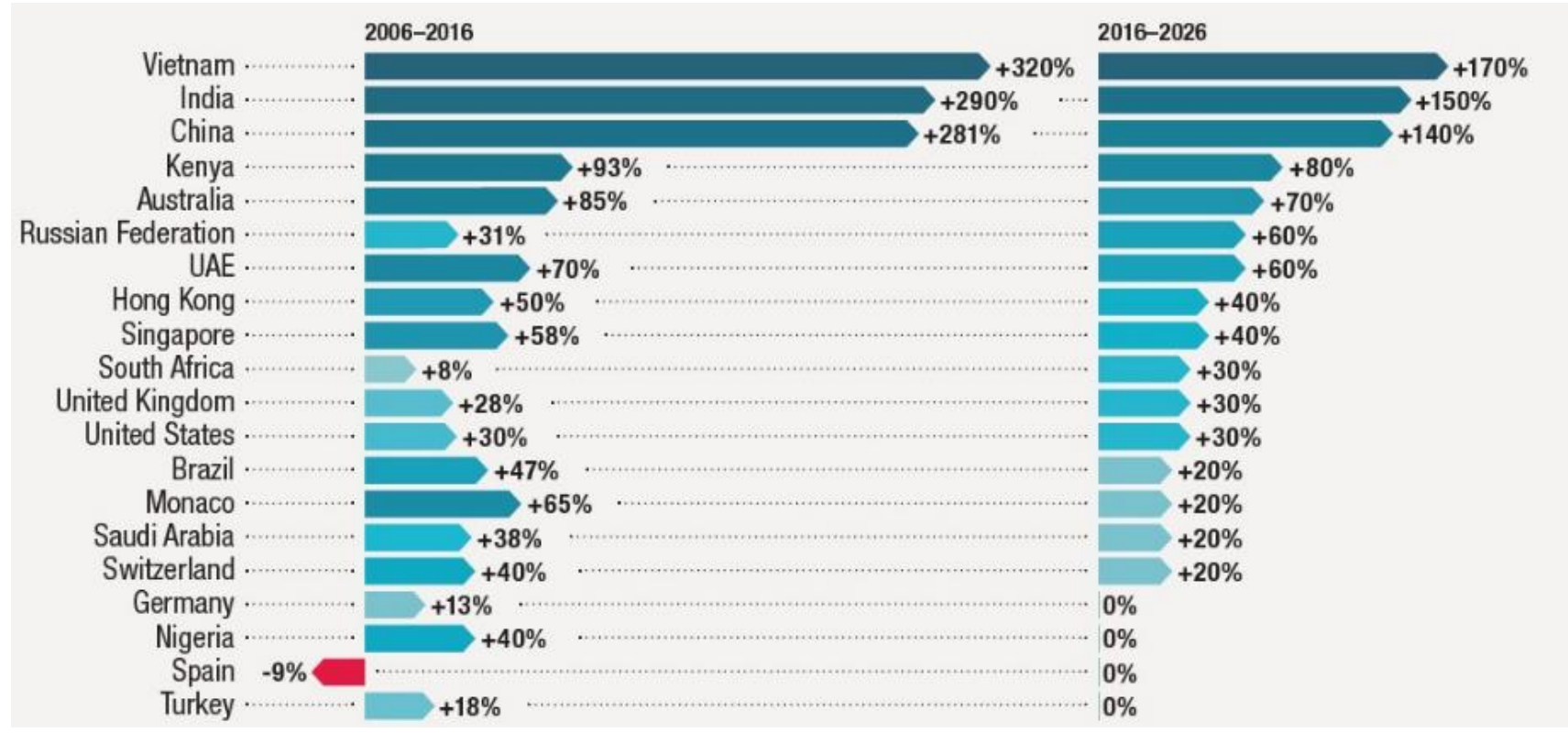

Source: Knight Frank (2017). The Wealth Report 2017, first figure on p. 14.

Instead of focusing on income inequality, the comparison of the HDI and the IHDI is a better and broader measure as it covers inequality in terms of income, quality of life, and knowledge. Though the IHDI is only available for Vietnam since 2010, Figure 32 nevertheless shows a reduction in the gap between the two measures from 2010 to 2011, and a widening gap since 2011, especially from 2013 to 2014, when the HDI continued to rise while the IHDI declined. Overall, the difference between HDI and IHDI increased from 16.3 percent in 2010 to 17.7 percent in 2015, hence, indicating an overall worsening inequality.

To get a better understanding of the relationship between income inequality and inequality in human development, Figure 33 compares the evolution of the Gini Index with the evolution of the difference between HDI and IHDI for all years both data is available (2010-2015). Despite the very limited time period for which we have data for both indicators, there seems to be some consistency in the evolution of these two inequality measures. Both seem to decrease initially, the Gini between 2010 and 2012, and the difference between HDI and IHDI from 2010 to 2011. The Gini then remains more or less stable at around 35 percent between 2012 and 2015, while inequality in human development seems to have increased since 2011.

In Vietnam, inequality exists both within and between urban and rural populations, regions, and ethnic groups, and tends to persist across generations. Additionally, as a new MIC, pressure to ensure equality will emerge as the economy becomes more complex and differentiated. As the GoV has recognized, the negative social effects of inequality are further accentuated by people's perceptions. ${ }^{85}$ It suggested focusing on policies that promote inclusive growth and narrow the gap in opportunities, labor market policies, and the provision of high-quality vocational training. It also recognized that it needs to address access to quality education and health care. ${ }^{86}$ 
Figure 32: Evolution of HDI and IHDI, 2010-2015

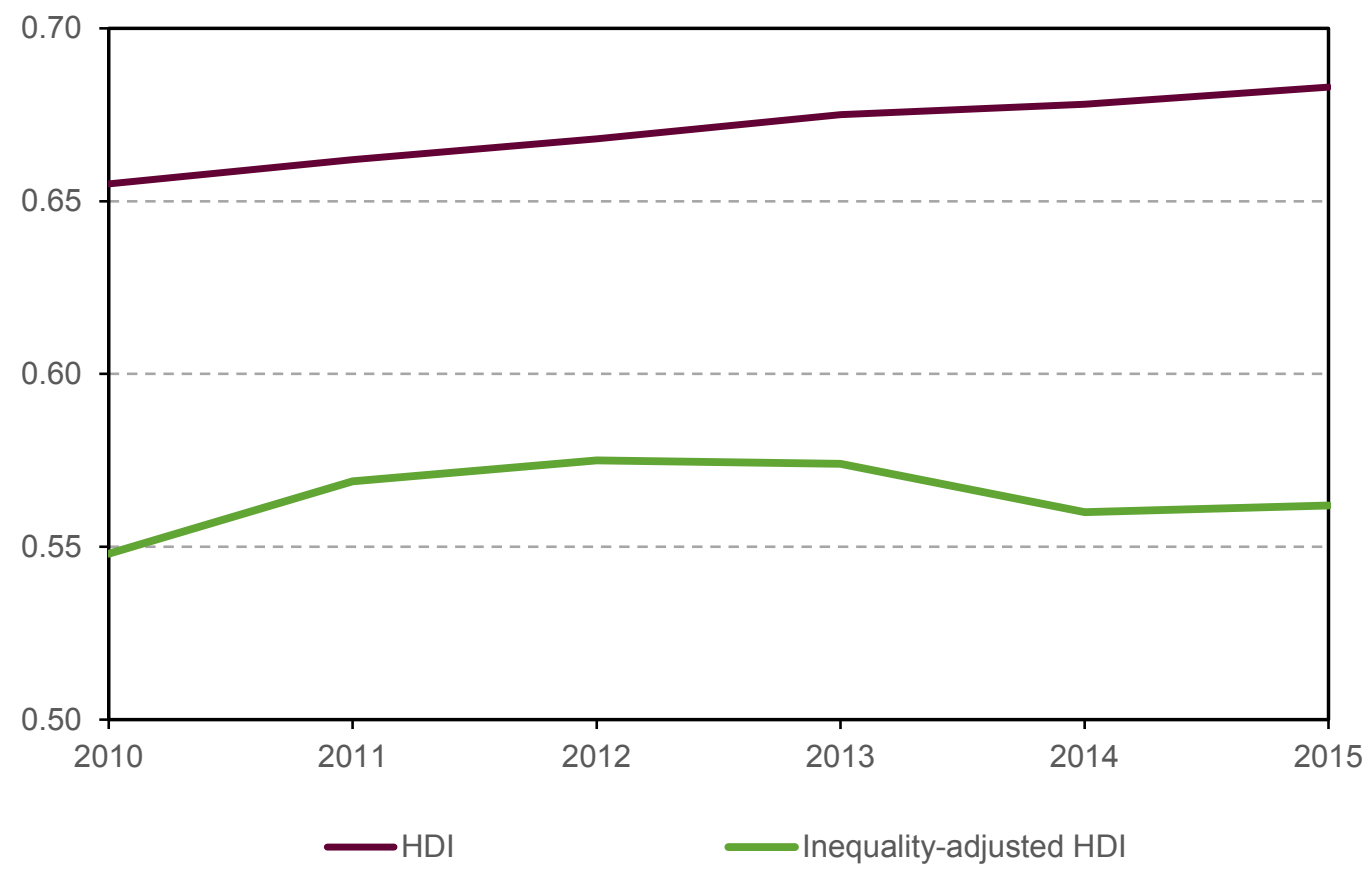

Note: The bigger the difference between HDI and IHDI, the larger is inequality.

Source: Based on UNDP's Human Development Data website, downloaded June 5, 2018.

Figure 33: Inequality in human development and income inequality, 2010-2015

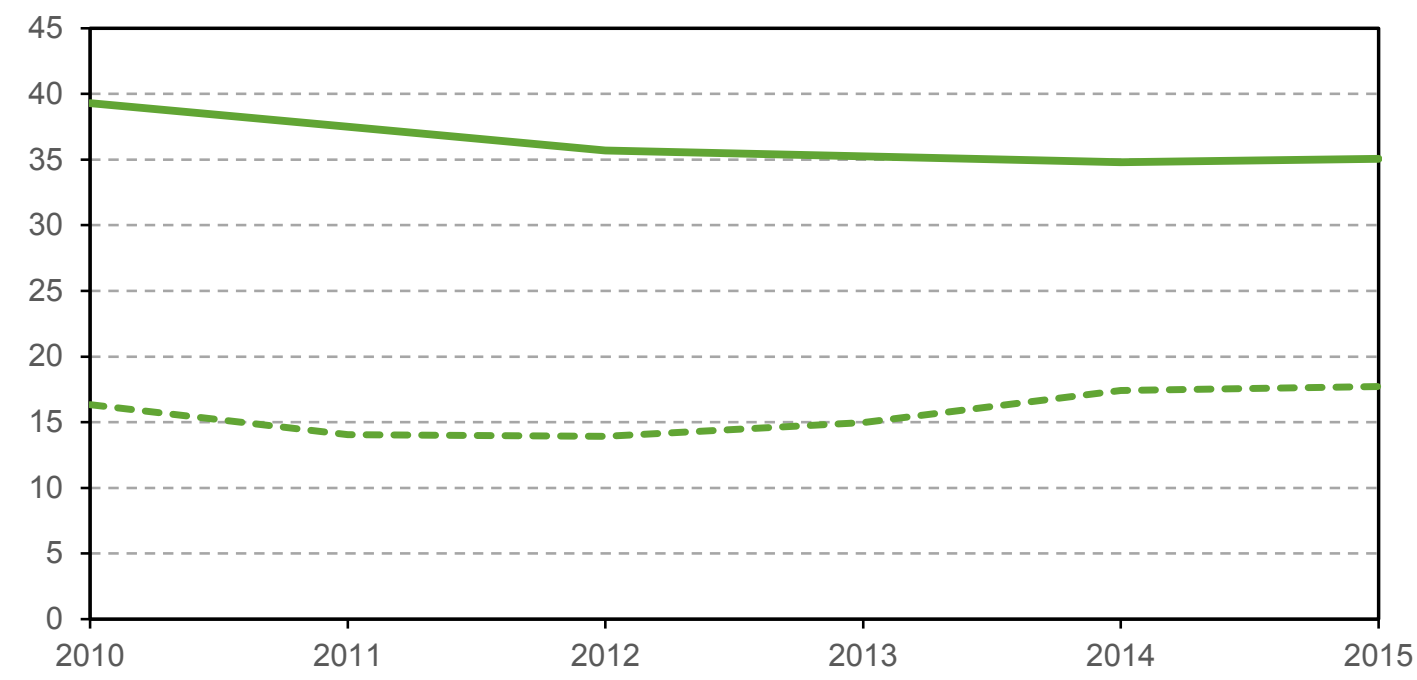

- Difference between HDI and IHDI (\%) [an increase in this \% implies increasing inequality] Gini in \% (World Bank estimate of 2018; odd years are averages of even years)

Source: Calculated based on UNDP's Human Development Data website; World Bank (2018), WDI/IDA database; and World Bank (2018), Poverty Report. 
One recently published study by Dang Thi Thu Hoai $(2018)^{87}$ examines the issue of horizontal inequalities in Vietnam over the past 20 years. Using data from three recent Vietnam population censuses (1989, 1999, and 2009) and three Vietnam Household Living Standard Surveys (1998, 2008, and 2012), the study concludes that horizontal inequality matters in Vietnam (in particular for ethnicity, region, and rural/urban groups), that there has been an improvement in horizontal inequality in education, and that horizontal inequality matters for poverty reduction in Vietnam.

Finally, a joint report by Development Finance International and Oxfam published in October 2018 ranks 157 governments across the world on their efforts in three policy pillars: social spending, taxation, and labor rights and wages to create the Commitment to Reducing Inequality Index. While Vietnam ranked $99^{\text {th }}$ in the overall Commitment to Reducing Inequality Index, it ranked $89^{\text {th }}$ in the social spending pillar, $46^{\text {th }}$ in the tax pillar, and only $126^{\text {th }}$ in the labor rights and wages pillar. ${ }^{88}$

\section{A.I.5 RECENT DEVELOPMENTS IN TERMS OF GENDER EQUITY}

Similar to inequality, progress on gender equity is a disputed issue in Vietnam. While some consider gender equity to have worsened, which may be partly due to many gender issues now being more openly discussed, including within government circles, there are some indicators that show improvements. This sub-section will first present some actual data, then summarize recent contributions that highlight major gender gaps, before closing with some promising signs.

One of the most comprehensive and respected indicators on gender equity is the World Economic Forum (WEF)'s Gender Gap Index. ${ }^{89}$ The WEF's Global Gender Gap Report 2017 benchmarks national gender gaps based on economic, education, health, and political criteria. In summary:

- Vietnam was ranked $69^{\text {th }}$ among a total of 144 nations.

- It scored higher in the sub-area of "Economic Participation and Opportunity," where it ranked $33^{\text {rd }}$.

- It ranked only $97^{\text {th }}$ in both the sub-areas of "Educational Attainment" and "Political Empowerment."

- It ranked at an incredibly low $138^{\text {th }}$ place within the sub-area of "Health and Survival," implying that Vietnam has significant women's health issues.

Figure 34 shows the evolution of Vietnam's overall score for all available years, with a higher score reflecting a smaller gender gap. Despite some volatility, gender inequality seems to have worsened from 2007 to 2011 and improved subsequently, though the 2017 score was slightly below the 2016 score. Future data will show if this was only a temporary decline or the start of a new trend.

Similarly, the World Bank's 2018 report on Poverty Reduction and Shared Prosperity in Vietnam ${ }^{90}$ shows that the ratio for female enrollment in upper secondary education has recently surpassed that of males. Enrollment rates for girls and boys are broadly equal from pre-primary to lowersecondary years and have increased at a similar pace. "In 2010, net enrollment rates in upper secondary education were also equal at about 34 percent, but by 2016 the rate for female students had risen to 43.5 percent, while the rate for male students had reached just 39.6 percent. Similarly, the upper secondary completion rate among females aged 20-24 was 67 percent in 2016, compared to 51 percent for male students" (p. 10). ${ }^{91}$ However, the fact that enrolment rates for girls are higher in tertiary education should not be taken to mean that Vietnam has achieved gender equality. 
Despite making significant progress in enrolment and educational attainment, women in Vietnam continue to earn less than men, which is partly explained by woman having lower-paid occupations. One recent research report found that women in Vietnam may forego higher pay to work in occupations and industries that offer better non-monetary benefits: paid leave, fewer hours, health insurance, and social insurance. This choice may be driven by an unequal distribution of houseand care-work. ${ }^{92}$

Figure 34: Vietnam's score in the WEF's Global Gender Gap Index, 2007-2017

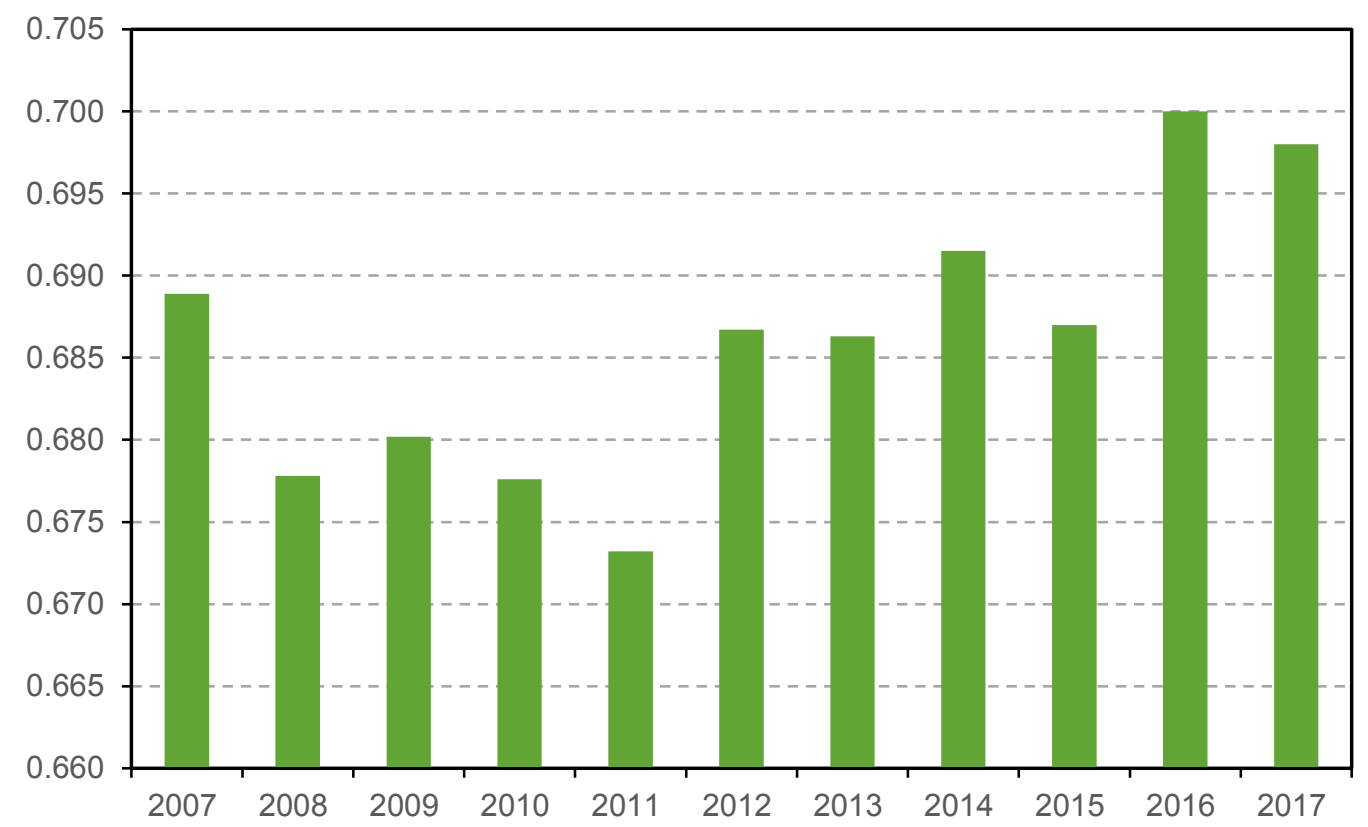

Note: A higher score implies a reduction in gender gap.

Source: Compiled based on data provided in various editions of the WEF's Global Gender Gap Report.

In any case, in 2017, Vietnam's Deputy Prime Minister Phạm Bình Minh said that economic growth can only be sustained if the status of women is improved. In the ASEAN region, gender inequality is causing a loss of 18 percent of ASEAN's GDP each year, which is equal to half a billion US dollars, according to Minh. ${ }^{93}$ Women's labor participation is far lower than that of men, and the gap has increased slightly over time. In 1996, the female labor participation rate was 72.6 percent, while it was 79.4 percent for males, a difference of 6.8 percentage points. In 2016, the female labor participation rate was 72.0 percent for women and 81.5 percent for men, a gender gap of 9.5 percentage points.

Kamal Malhotra, co-chair of the Informal Ambassadors and Heads of Agencies Gender Policy Coordination Group and the Resident Coordinator of the United Nations in Vietnam, has stated that that there are multiple barriers to women in Vietnam enjoying equal access to, participation in, and progress in the labor market. The Labor Code, Vietnam's labor law, reflects the presumption that only women have responsibility for family and home care. This wrongly provides a rationale for excluding women from jobs that are considered unsuitable for them. Furthermore, the Labor Code encourages providing occupational skills training to female employees "that is suitable to their physical and physiological characteristic and their motherhood functions." The notion that a particular skill, job, or industry is better suited to one sex leads to horizontal segregation of the labor market, often clustering women into the informal sector and lower-paying jobs. 
Malhotra also points out that women in Vietnam face the challenge of vertical segregation. In general, the chances for women to reach leadership positions and have a voice of influence in current affairs are limited. One of the bottlenecks is the unequal retirement age for women (55) and men (60) provided for in the Labor Code. Because women are required to retire earlier than men, and are also expected to take time out from work to raise children and care for family members, they are denied an equal chance of career advancement. ${ }^{94}$ In a 2015 reports facilitated by the International Labor Organization, one in five job postings in Vietnam included gender requirements. Among the postings with a gender preference, up to 83 percent of management positions and all director positions specified they wanted male applicants. ${ }^{95}$

Malhotra explains that "such gender segmentation of the labor market also resulted in a widening gender earning gap in Vietnam, contrary to the global trend. The gender gap in the average monthly salary of paid workers is equivalent to women working for free for one month every year. As long as institutions and policies are established or shaped based on traditional stereotypical gender roles, they will continue to shape and inhibit labor market opportunities and incentives for women. Because of these underlying issues, economic gains have not translated into greater gender equality. While international integration and free trade may bring opportunities for growth, they can exacerbate disadvantages already faced in Vietnam. Vietnam's economy is largely built on exporting low value-added products and, therefore, results in a concentration of low-tech and lowskill production that is also labor intensive." In fact, as quoted by Malhotra, International Labour Organization estimates indicate that 85 percent of textile, clothing, and footwear workers in Vietnam are at risk of being replaced by automation and robots. This could have a profound impact on women workers in particular who, across all industries in Vietnam, are 2.4 times more likely than men to be employed in an occupation at high risk of automation.

Figure 35 compares female labor participation rates across countries and is based on surveys and studies conducted by a network for migrant workers called M.net, set up by Oxfam and six Vietnamese non-governmental members. As revealed in a recently released report from the Centre for Development and Integration, some 72 percent of Vietnamese women have joined the labor force, which is higher than the average world percentage (42 percent), and ranking only behind Cambodia (81 percent). According to the report, the number of female laborers (doing unskilled manual work) in Vietnam accounts for 48.4 percent of the total labor force, while male laborers account for 51.6 percent. However, women still face inequalities at work.

As reported by Vietnam News (2018): "Women make up for more than 70 percent of the labor force in the textile, leather shows, and electronics sectors. However, they benefit only a small value of the global supply chain. In the textile sector, labor cost accounts for only 2 percent of the wholesale price of a product, while employers enjoy 16 percent of the profit. Companies cause pressure to reduce labor cost. As a consequence, Vietnamese laborers have to take on a heavy workload, with more working hours but lower wages." 96

Furthermore, the report also points out gender inequality at work in Vietnam: "As many as 7.8 million female laborers of the non-official labor sector work in poor conditions. Nearly 60 percent of unofficial female laborers have to take on work with low wages, bad security at work, and lack of welfare, while the figure for male laborers is only 31.8 percent. There are more barriers for women than men in terms of career development at all skill levels. Only 26 percent of leading positions are occupied by women, while women take on more than 52 percent of simple work and 66.6 percent of household work. Women make up over 57 percent of the unemployed in the group of unskilled laborers and more than half of the group receiving vocational training. Some 55 percent of unemployed women hold a bachelor's degree. Women are paid 11 percent lower than men for similar work. The gap is widened in groups at higher skill levels." ${ }^{97}$ 
Figure 35: Comparison of women in the labor force across countries in 2010

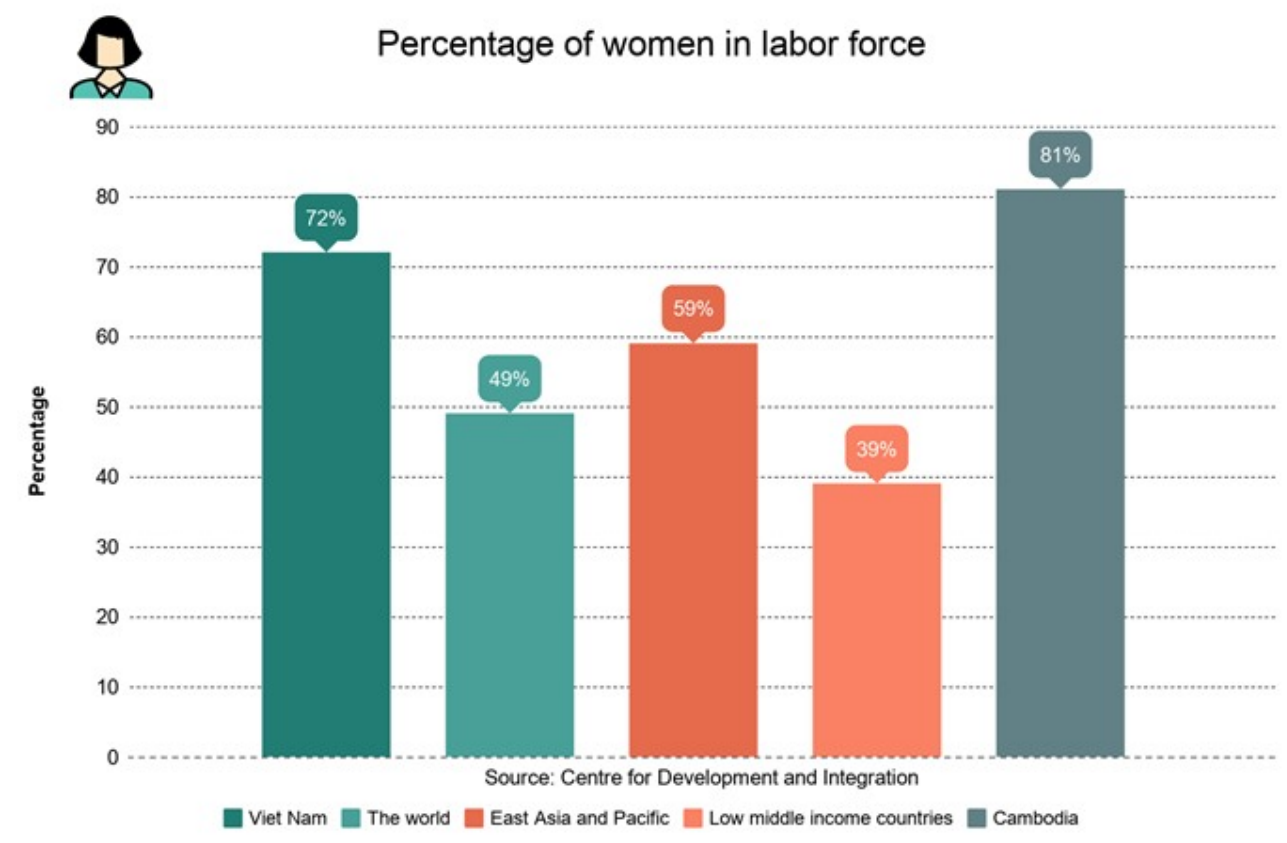

Source: VNS Infographic Khánh Dương. Available at: http://image.vietnamnews.vn//uploadvnnews/Article/2018/1/24/laborinfopgr688113916AM.png

According to the Global Partnership for Effective Development Co-operation: "At this stage, Vietnam has not yet adopted gender-specific and sex-disaggregated indicators to allocate budget and track public expenditures. The new National Action Plan on Gender Equality (NAPGE) 2016-2020 as well as the annual State Budget Law provide a number of entry points to track specific gender equality programmes, which might lead to more sophisticated instruments in the future." 98

In addition to facing discrimination in the work place, women also face domestic abuse. Based on a national survey by the General Statistics Office and supported by the United Nations Agencies in Vietnam, with funding from the Australian Embassy in Vietnam, about 58 percent of ever-married women aged 18-60 have experienced violence in a family setting at least once in their lives.

Furthermore, a huge concern is that up to 87 percent of women suffering from violence do not seek support from public service providers, according to a report from the National Survey on Violence against Women in Vietnam. ${ }^{99}$ Finally, women have poorer access to formal credit than men. ${ }^{100}$

\section{Some promising signs}

Though most of the issues addressed in the last sub-section paint an overall negative picture of gender equity in Vietnam, there are some areas where Vietnam stands out. Globally, 72 percent of men and 65 percent of women had a bank account in 2017, a gender gap of 7 percentage points. The gender gap is similar in developing economies, with 67 percent of men but only 59 percent of women having a bank account in 2017. However, there is no significant gender gap in Vietnam; the percentage of people having a bank account in Vietnam in 2017 was low, at 31 percent, but it was the same for men and women. ${ }^{101}$

Another positive aspect is that Vietnam's Land Law ensures joint titling when land use rights are jointly held and houses jointly owned. Strong property rights and titling schemes encourage asset- 
based lending, or loans secured by collateral. Having titled property is important for women in Vietnam, where entrepreneurship offers a chance to overcome poverty. Sons and daughters, as well as female and male surviving spouses, have equal inheritance rights in Vietnam. ${ }^{102}$

Finally, in 2016, Vietnam introduced five days of paid paternity leave provided by the government, which is rare among LMICs. As well as giving new fathers time with their family, providing paid paternity leave may mean women get more support at home and employers discriminate against hiring women less. ${ }^{103}$

\section{A.I.6 RECENT DEVELOPMENTS IN TERMS OF SOCIAL MOBILITY}

A recent Oxfam (2018) study analyzed the trends and impact factors for social mobility and equality of opportunity in Vietnam. ${ }^{104}$ Some of the key conclusions of the study are as follows.

First, occupational mobility is slow, with 79 percent of agricultural workers in 2004 continuing to work in agriculture in 2008, rising to 83 percent during the 2010-2014 period. Meanwhile, fewer than 8 percent of agricultural workers moved to the industry or service sectors during either period. Furthermore, in both periods (2004-2008 and 2010-2014), only approximately one-fifth of manual or traditional sector workers moved to the skilled workers groups (skilled "blue collar" and nonmanual "white collar" workers. During the 2004-2008 period, the ratio of ethnic minority manual workers moving to blue collar work was 2 percent, while that of Kinh (ethnic Vietnamese) people was 15 percent. Remarkably, a significant proportion of workers moved from industry to agriculture and from skilled jobs (blue collar) to manual/traditional jobs.

Second, intra-generational income mobility has slowed down in recent years. National statistics showed that 45 percent of households in the poorest group in 2004 moved to higher income quintiles after four years (by 2008). From 2010-2014, this proportion was 37 percent. The slowdown is more clearly demonstrated among younger people, as 33 percent of the poorest households headed by people aged 15-30 entered higher income groups in 2008 compared with 2004 , but only 16 percent did so for 2010-2014. In the 31-60 age group, the proportion entering higher income groups declined from 46 percent to 39 percent for the same period. In terms of ethnicity, while 49 percent of the poorest Kinh households in 2010 had entered higher income groups by 2014, only 19 percent of ethnic minority-headed households did the same.

Third, inter-generational occupational mobility is also low. During the 2010-2014 period, 42 percent of people aged 15-60 whose parents worked in the agricultural sector were themselves working in non-agricultural sectors. This was 10 percent higher than in 2004-2008. The mobility rate from agricultural to non-agricultural work was higher among urban residents, women, adults, and the Kinh and Hoa groups than for rural people, men, young people, and ethnic minority groups.

Fourth, the Oxfam (2018) study also examined inter-generational skill mobility, coming to the conclusion that the higher a child's educational attainment, the more skill mobility they have compared with their parents. For children whose parents were unskilled/traditional manual workers, 79 percent of those graduating from college or higher and 42 percent of those with upper secondary diplomas had skilled jobs in 2014 . However, there is disparity in mobility between urban and rural areas, between men and women, between age groups, and particularly between the Kinh and Hoa groups and ethnic minority groups. Finally, examining inter-generational mobility trends in income, the most recent 10 years showed a modest increase. Benchmarking against international cases shows that income mobility of children compared with their parents in Vietnam is at an average level. 
With regards to the factors influencing social mobility, Oxfam (2018) showed that educational attainment is the most important factor that helps foster social mobility. However, there is a strong correlation between parents' socio-economic status and educational attainment and that of their children. A higher family economic status also increases children's chances of finding a job, particularly in areas that have few jobs requiring skilled workers. Besides, multiple forms of community support, particularly among ethnic minority communities, could play a role in the upward mobility of individuals and households. Furthermore, agricultural development is important in order for ethnic minorities to increase their income through optimizing land potential, promoting intensive cultivation to increase productivity, and restructuring their crops and livestock. On the other hand, poor-quality education is a major barrier to accessing skilled jobs, and the disparity in having access to education between poor and rich people adversely affects the social mobility of those living in poverty. 


\section{ANNEX II: RECENT TRENDS IN PRIVATE EXTERNAL DEVELOPMENT FINANCE}

There are a number of different external sources that might finance development. For analytical purposes, external development finance is divided into public and private resources.

- External public resources are resources provided to the GoV and other state entities, such as state-owned enterprises, regardless of whether they come from another government (i.e., bilateral assistance), an international organization (i.e., multilateral assistance), or external private sources (such as foreign commercial banks loans and sovereign bonds). Public external resources can be concessional or non-concessional.

- Concessional resources are provided either via grants or loans with an interest rate below the market interest rate. So-called ODA is either in the form of grants or concessional loans with a grant element of at least 25 percent (using the rules in place for the last few decades, but soon to change).

- Non-concessional public resources are loans (from either foreign governments, international organizations, or foreign commercial banks) or sovereign bonds issued by the Vietnamese government.

- External private resources are defined as resources provided to Vietnamese individuals (like remittances or donations) and/or to the Vietnamese private sector (like loans from foreign commercial banks, private bonds raised in foreign currency, FDIs, and PIs). With the exception of remittances and private donations, private external resources are typically never concessional. While all private external resources may support the Vietnamese economy, private sector loans, FDIs and PIs are typically not considered to be development finance.

Figure 36 breaks down the total net transfers on PPG external debt in terms of bilateral, multilateral, and private creditors. Net transfers are disbursements minus debt service payments (which are the sum of principal repayments and interest payments). Given the relatively high interest rate and amortization payments on private loans to the GoV (or guaranteed by the GoV), we provide data as net transfers. This is because gross disbursements for loans provided by the private sector would give the wrong picture of how much external development finance is effectively available to the GoV.

Figure 36 seems to indicate that bilateral net transfers show a slightly declining trend since 2012 , though the relatively high volatility makes it difficult to come to a conclusion. The same applies to net transfers on multilateral loans, which reached their maximum in 2009 but spiked again in 2013. However, net transfers on multilateral loans have clearly declined since 2013. Net transfers from external private creditors (which include sovereign bonds and commercial banks) are highly volatile and were negative in both 2015 and 2016, that is, the GoV paid more on interest payments and amortizations than it got from private sources. Combining all sources (bilateral, multilateral, and private), net transfers on external loans reached a maximum of $\$ 4.37$ billion in 2013 , after which there was a continual decline, reaching $\$ 1.13$ billion in 2016 .

Figure 36: Net transfers on PPG external debt by creditor (\$ million), 1990-2016 


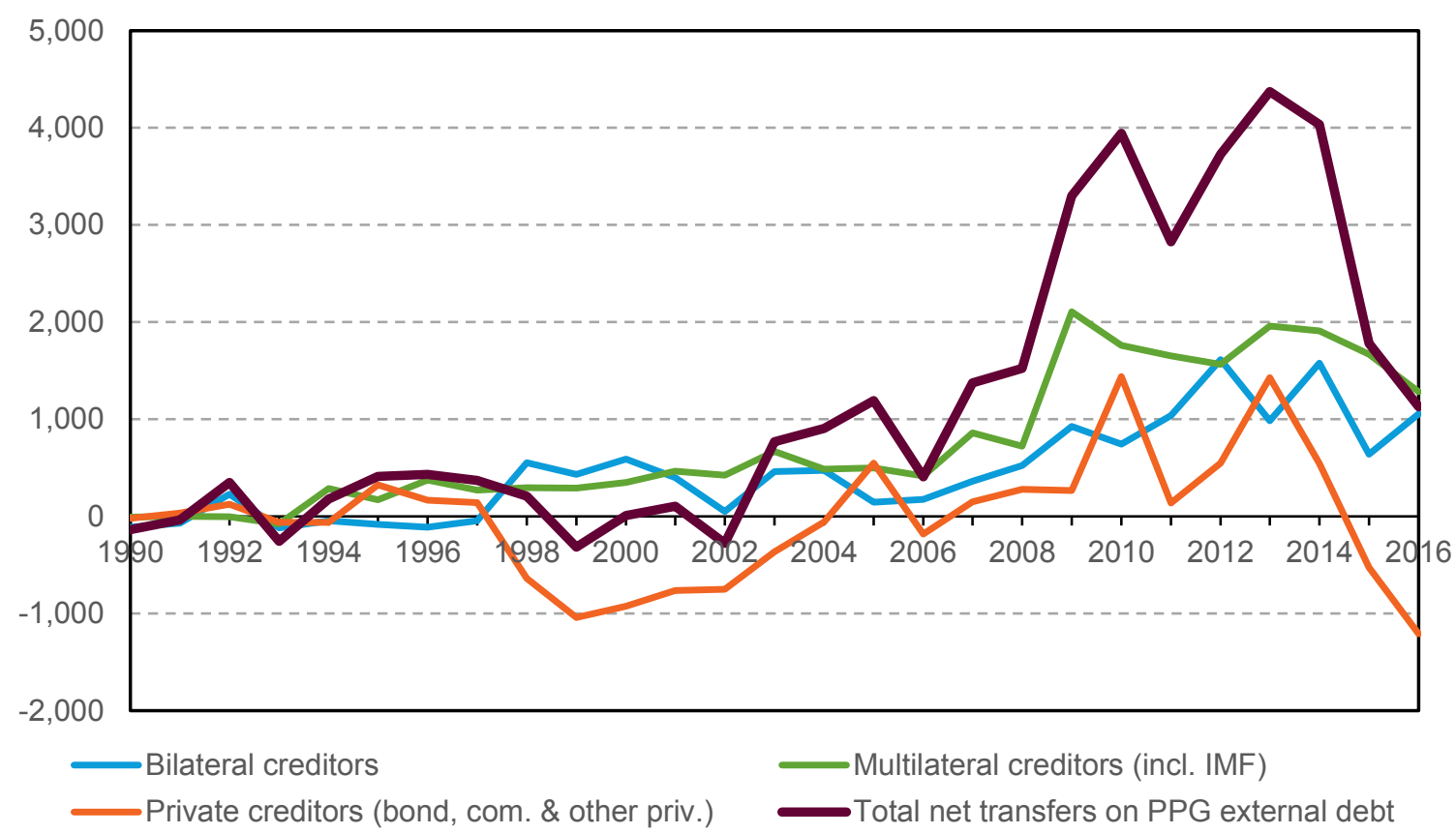

Source: Based on World Bank (2018), WDI/IDS database.

Figure 37 shows the evolution of net transfers on private non-guaranteed (PNG) external debt, net FDI inflows, net PI, and remittances, though we also provide the data for net transfers on PPG external debt to get an idea on the relative size of public and private external development finance.

- Data for PIs is only available from 2005-2015 and seems to be highly volatile. Inflows from this source are typically very low (amounting to an annual average of \$552 million during 20132015), the only two exceptions are 2007 and 2010, when PI inflows reached, respectively, $\$ 6.24$ billion and $\$ 2.38$ billion.

- Though data on PNG external debt is only available since 2010, the graph seems to indicate an increasing trend. Net transfers on PNG external debt were initially small, though they overtook net transfers on PPG external debt in 2015 and 2016.

- Compared with more recent years, FDI inflows were relatively small until 2006, but then skyrocketed in 2007 (reaching $\$ 9.58$ billion), and have shown a solid increasing trend since 2011 , reaching $\$ 12.6$ billion in 2016, which is more than 10 times the very low net transfers on PPG debt in 2016. Excluding 2016, net transfers on PPG external debt have been about half of the net FDI inflows during the last 10 years.

- Remittances (for which data is available since 2000) also show a solid upward trend, despite a slight decline in 2016, and have been the largest source of external development finance from 2010-2015, though given the nature of remittances (i.e., they are directly consumed, meeting basic needs, by the families of migrant workers), they should not be classified as development finance. 
Figure 37: FDI, PI, remittances, and net transfers on PPG and PNG external debt (\$ million), 1990-2016

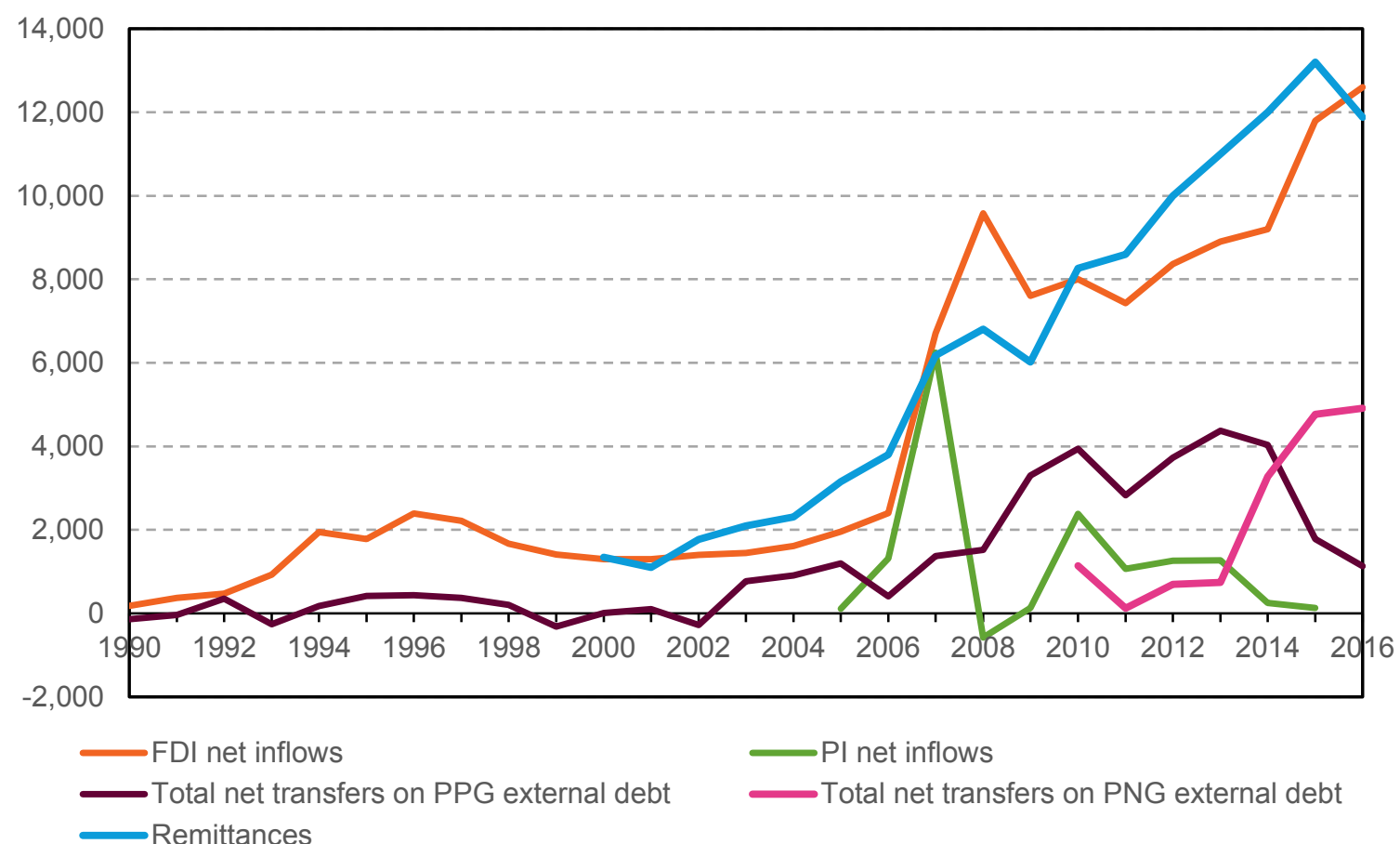

Source: Based on World Bank (2018), WDI/IDS database.

As stated in a joint 2014 report by the United Nations Agencies in Vietnam, the Delegation of the EU to Vietnam, and the Ministry of Planning and Investment of Vietnam, there are some concerns about the quality of FDI in Vietnam: ${ }^{105}$

Investments in low value-added textiles and simple assembly operations still predominate. Many foreign companies bring their components from abroad and export their product, offering few opportunities for private firms to become part of international value chains or acquire new management skills or technology. The danger is that, as wages increase, Vietnam will begin to lose out to lower-wage economies in the region such as Myanmar. FDI levelled out or declined slightly after the global financial crisis but appears to have picked up again since 2013.

To avoid this 'middle-income trap' Vietnam needs to attract a higher quality of foreign and domestic investment into higher productivity industries, enabling it to build up domestic value chains. There are some encouraging signs that this is starting to happen in subsectors such as mobile phones, where a number of major foreign investors have begun to shift production into Vietnam. Generally, however, analysts are concerned that infrastructure bottlenecks, skills shortages and restrictions in the business environment are standing in the way of more substantial growth in high-technology industries. 
Finally, even though some of the resources from so-called public-private partnerships come from domestic enterprises, given that the majority of Vietnam's public-private partnerships have involved foreign enterprises, this paragraph gives a very brief overview of money raised via infrastructure public-private partnerships. According to the World Bank's Private Participation in Infrastructure Database, ${ }^{106}$ there have been 96 such infrastructure projects totaling $\$ 14.7$ billion from 1990-2017. From 2013-2017, there were seven projects, totaling to investments of $\$ 5.3$ billion. This includes a $\$ 2.4$ billion investment in 2017 by the Malaysian company Teknik Janakuasa for the Duyên Hải-2 Thermal Power Plant via a so-called build-operate-transfer (BOT) contract.

Public-private partnerships have been controversial given that they are often non-transparent, antipoor, and ultimately a liability for the public sector. ${ }^{107}$ Public-private partnerships should be scrutinized thoroughly to assess their impact on poverty and inequality as well as their potential financial liability for the public sector. 


\section{ANNEX III: PROSPECTS FOR EXTERNAL DEVELOPMENT FINANCE}

Given that trying to predict future external development finance to Vietnam would involve too much speculation, this sub-section focuses on four issues. First, we review briefly how IDA graduation may affect the lending of other donors and private investment institutions. Second, we review the World Bank's CPF for Vietnam, which covers FY2018 to FY2022. Third, we review the World Bank's new "Maximizing Finance for Development" agenda, and finally, we examine briefly the prospects for future bilateral development finance, including the impact the new DAC ODA rules may have on bilateral flows.

\section{A.III.1 IMPACT OF IDA GRADUATION ON OTHER DONORS AND PRIVATE INVESTMENT}

Though the coordination of aid has improved significantly over the last few decades, there does not seem to be any explicit coordination of each donor's transition process. The decision of a donor to reduce or stop providing aid to any specific country is usually the autonomous decision of each donor. There are, however, some initiatives like Gavi (The Vaccine Alliance) ${ }^{108}$ that now use a country's GNI per capita (according to World Bank data) to determine eligibility. When a country graduates from the UN's LDC classification, there are considerable implications related to various preferential trade agreements, like the European Union's Everything but Arms initiative. ${ }^{109}$ But graduating from LDC status does not directly affect most donors' aid allocation. In any case, according to the United Nations Conference on Trade and Development (UNCTAD), ${ }^{110}$ Vietnam was never classified as an LDC. Most donors refer to terms like LDC, LIC, or MIC in their general aid policies and frameworks, but being re-classified from a LIC to a MIC does not automatically trigger a change in aid allocation. However, it sends a signal to the donors, most of which will then start relooking at their aid allocation to that country.

There are some indications that total net ODA to Vietnam has increased from 2016 to 2017, but will now continue to gradually decrease, especially as (a) IDA made its last concessional contribution to Vietnam in 2017 and (b) Vietnam is scheduled to graduate from concessional financing from the ADB on January 1, 2019. ${ }^{111}$ Given that the OECD (2018) has published data for CPA from 2012 to 2019, we can estimate Vietnam's ODA from 2017-2019 based on the ratio of CPA and net ODA from 2012 to 2016. ${ }^{112}$ As shown in Box 4 below, using this method, the estimated net ODA for Vietnam is $\$ 3.5$ billion, $\$ 3.48$ billion, and $\$ 3.34$ billion for, respectively, 2017,2018 , and 2019 . While this is a little more than the actual average net ODA of 2014-2016, based on all current information, net ODA is expected to slowly decline after 2017.

The information in Box 4 allows us to make some comparisons of recent ODA flows to Vietnam, Bolivia, and Sri Lanka. While Vietnam is getting far more ODA than Bolivia or Sri Lanka in absolute terms, as the 2018 column shows, Vietnam's net ODA per capita of $\$ 36.60$ is between the per capita net ODA received by Bolivia (\$67.20) and Sri Lanka (\$20.40). 
Bolivia still has far higher poverty rates than Vietnam and faces significant challenges on the poverty reduction and shared prosperity agenda. Around 39 percent of Bolivians are still living in poverty and 17 percent living in extreme poverty. A large proportion of households that are now above the poverty line could fall back into poverty if there was a slowdown or any negative shock. ${ }^{113}$

Poverty in Sri Lanka is also higher than in Vietnam. Using Sri Lanka's national poverty line, which is equivalent to about $\$ 1.50$ a day (2011 PPP), the poverty rate fell from 22.7 percent in 2002 to 6.7 percent in 2012-2013. ${ }^{114}$ Using the higher \$1.90-a-day poverty line (2011 PPP), Vietnam's poverty rate in $2012-2013$ was only 2.8 percent.

\section{Box 4: CPA for Vietnam, Bolivia, and Sri Lanka, 2012-2019}

Table 6 shows the actual CPA for Vietnam, Bolivia, and Sri Lanka, which can be compared with actual net ODA receipts for 2012-2016. We then use the country-specific average ratio of CPA to actual ODA receipts for 2014-2016 to estimate net ODA receipts for 2017-2019. While this ratio obviously changes from year to year, it can be used to estimate net ODA receipts for Vietnam, as this ratio has remained relatively stable for the country. Using this method, average annual net ODA receipts for Vietnam for 2017-2019 is estimated at $\$ 4.13$ billion, which compares to an average annual net ODA receipts of $\$ 4.08$ billion for 2014-2016.

Table 6: Net ODA projections for 2017-2019 (based on CPA) in \$ million, unless otherwise indicated

\begin{tabular}{|c|c|c|c|c|c|c|c|c|c|c|c|c|}
\hline & & 2012 & 2013 & 2014 & 2015 & 2016 & 2017 & 2018 & 2019 & $\begin{array}{l}\text { Average } \\
\text { 2014-2016 }\end{array}$ & $\begin{array}{l}\text { Average } \\
\text { 2014-2016 } \\
\text { per capita } \\
\text { (\$) }\end{array}$ & $\begin{array}{l}\text { Average } \\
2017- \\
2019\end{array}$ \\
\hline \multirow[t]{4}{*}{ Vietnam } & CPA & 4,584 & 4,566 & 4,810 & 3,771 & 3,659 & 4,198 & 4,177 & 4,005 & 4,080 & 43.6 & 4,127 \\
\hline & $\begin{array}{l}\text { Actual net ODA } \\
\text { receipts }\end{array}$ & 4,113 & 4,086 & 4,216 & 3,157 & 2,893 & & & & 3,422 & 36.6 & na \\
\hline & $\begin{array}{l}\text { Projected net ODA } \\
\text { receipts }^{*}\end{array}$ & & & & & & 3,498 & 3,481 & 3,337 & na & & 3,439 \\
\hline & $\begin{array}{l}\% \text { of } C P A \text { in net } \\
\text { ODA }\end{array}$ & 111.4 & 111.7 & 114.1 & 119.4 & 126.5 & 120.0 & 120.0 & 120.0 & 120.0 & & 120.0 \\
\hline \multirow[t]{4}{*}{ Bolivia } & CPA & 619 & 664 & 642 & 565 & 600 & 760 & 776 & 799 & 602 & 56.1 & 778 \\
\hline & $\begin{array}{l}\text { Actual net ODA } \\
\text { receipts }\end{array}$ & 662 & 702 & 675 & 791 & 696 & & & & 721 & 67.2 & na \\
\hline & $\begin{array}{l}\text { Projected net ODA } \\
\text { receipts }{ }^{*}\end{array}$ & & & & & & 902 & 921 & 949 & na & & 924 \\
\hline & $\begin{array}{l}\% \text { of } C P A \text { in net } \\
\text { ODA }\end{array}$ & 93.5 & 94.6 & 95.2 & 71.4 & 86.1 & 84.2 & 84.2 & 84.2 & 84.2 & & 84.2 \\
\hline \multirow[t]{4}{*}{ Sri Lanka } & CPA & 902 & 784 & 869 & 696 & 778 & 803 & 798 & 788 & 781 & 37.2 & 796 \\
\hline & $\begin{array}{l}\text { Actual net ODA } \\
\text { receipts }\end{array}$ & 491 & 403 & 492 & 427 & 365 & & & & 428 & 20.4 & na \\
\hline & $\begin{array}{l}\text { Projected net ODA } \\
\text { receipts* }\end{array}$ & & & & & & 436 & 433 & 427 & na & & 432 \\
\hline & $\begin{array}{l}\% \text { of CPA in net } \\
\text { ODA }\end{array}$ & 183.7 & 194.4 & 176.7 & 162.9 & 213.1 & 184.2 & 184.2 & 184.2 & 184.2 & & 184.2 \\
\hline
\end{tabular}

Note: *Based on country-specific CPA-to-ODA ratio from 2014-2016.

Source: OECD (2018). Country Programmable Aid (CPA) (indicator). DOI: 10.1787/69d8099b-en (accessed on 25 May 2018) and OECD Table 25e.

With regards to non-concessional aid flows to Vietnam, the picture is highly uncertain. As will be detailed in the next sub-section, there will be some substitution of concessional loans with nonconcessional loans by the World Bank. Similarly, the ADB has stated that it will compensate Vietnam for the cessation of concessional assistance with non-concessional assistance. ${ }^{115}$ The ADB also stated:

While traditional sources of development assistance are declining, new market-based sources are emerging. The merger of the ADF [Asian Development Fund] with the ADB ordinary capital resources (OCR) balance sheet will allow ADB to expand its market-based 
lending support. At the same time, potential new development finance providers are emerging and there is progress in mobilizing greater private sector investment, including through the use of public-private partnerships. ${ }^{116}$

Finally, with regards to private financial flows to the GoV, a gradual increase can be expected, though the loan amounts and loan terms will depend on the perceived financial stability of the Vietnamese government.

\section{A.III.2 REVIEW OF THE WORLD BANK'S COUNTRY PARTNERSHIP FRAMEWORK}

On May 30, 2017, the World Bank adopted its new CPF for Vietnam, which covers FY2018 to FY2022 (i.e., July 2017 to June 2022). ${ }^{117}$ The CPF states that the GoV has approved $\$ 90$ billion in its 2016-2020 medium-term investment plan (MTIP), of which ODA/less concessional loans make up about $\$ 13.5$ billion. However, since Vietnam graduated from IDA on July 1, 2017, the World Bank has no plans to provide any concessional funds to Vietnam. Instead, the indicative lending program outlined in the CPF for FY2018-FY2020 (first three years) details \$1.56 billion via IDA transitional support on non-concessional (IBRD-like) terms, $\$ 1.84$ billion via IBRD lending, and a non-specified "other" of $\$ 0.22$ billion. Hence, this implies an average annual contribution of $\$ 1.21$ billion during FY2018-FY2020, which is nearly identical to the combined IDA and IBRD annual gross disbursements during calendar years 2014-2016 ( $\$ 1.24$ billion, of which $\$ 1.02$ billion were from the IDA).

The new CPF starts with a typical assertion of Vietnam's achievements, but stresses that development challenges persist. Two paragraphs (18 and 35) are useful to quote in this regard:
Poverty gains in Vietnam are fragile, with a significant portion of the population vulnerable to falling back into poverty. Among 2010's near poor, 17 percent had fallen back into poverty by 2014 . Sources of vulnerability include crop failure, induced by weather or climate shocks, insects or other pests; human disasters, including severe illness, death; and material crisis. In addition, many poor and near-poor households rely on informal sources of income, i.e., family farming, small household enterprises, and causal employment in the wage sector. Earnings in these sectors are typically variable and tend to be lower than in the formal sector. Small shocks can therefore relatively easily send households back into poverty.

Vietnam is one of the world's most vulnerable countries to climate change impact, including sea level rise, longer and more severe droughts and floods, and tropical cyclones; the poorest are the most exposed. By 2050, a 1 percent to 3 percent loss in real GDP is predicted from climate change impacts. Natural disasters have caused average annual economic losses estimated at 1 percent to 1.5 percent of GDP in the last two decades, and more than 70 percent of the population is already exposed to significant natural hazard risk. Ongoing climate disaster events and climate change effects can also set back development gains, particularly as safety net programs have not yet been adapted to support the poor and vulnerable in response to natural hazard shocks.

As is now standard in most donor program documents, the World Bank then stresses that "the CPF is fully aligned with the GoV's 2010-20 Socio-Economic Development Strategy (SEDS) and the recent 2016-20 Socio-Economic Development Plan (SEDP). The CPF responds to priorities for support expressed by the government and builds on the WBG's comparative advantage." With regards to areas the World Bank will provide support to Vietnam, the CPF is organized around three focus areas and 11 objectives, which are detailed in Table 7. 
Table 7: Focus areas and objectives of the World Bank's CPF for Vietnam

\begin{tabular}{|c|c|c|}
\hline $\begin{array}{l}\text { Focus Area 1: } \\
\text { Enable Inclusive Growth and } \\
\text { Private Sector Participation }\end{array}$ & $\begin{array}{l}\text { Focus Area 2: } \\
\text { Invest in People and Knowledge }\end{array}$ & $\begin{array}{c}\text { Focus Area 3: } \\
\text { Ensure Environmental } \\
\text { Sustainability and Resilience }\end{array}$ \\
\hline $\begin{array}{l}\text { 1. Strengthen economic } \\
\text { governance and market } \\
\text { institutions } \\
\text { 2. Promote private sector and } \\
\text { agri-business development } \\
\text { 3. Enhance trade competitiveness, } \\
\text { multi-modal transport } \\
\text { connectivity, and logistics } \\
\text { services } \\
\text { 4mprove planning, } \\
\text { management, and delivery of } \\
\text { infrastructure and land in cities } \\
\text { Broaden economic } \\
\text { participation of ethnic } \\
\text { minorities, women, and } \\
\text { vulnerable groups }\end{array}$ & $\begin{array}{l}\text { 6. Improve access to quality } \\
\text { public and private health } \\
\text { services and reduce } \\
\text { malnutrition } \\
\text { 7. Improve integration and } \\
\text { efficiency of social assistance, } \\
\text { pension, and health insurance } \\
\text { systems } \\
\text { 8. Strengthen the relevance and } \\
\text { quality of tertiary education } \\
\text { and labor market institutions }\end{array}$ & $\begin{array}{l}\text { 9. } \begin{array}{l}\text { Promote low carbon energy } \\
\text { generation, including } \\
\text { renewables and energy } \\
\text { efficiency, and reduce GHG } \\
\text { emissions }\end{array} \\
\text { 10. Increase climate resilience and } \\
\text { strengthen disaster risk } \\
\text { management } \\
\text { 11. Strengthen natural resource } \\
\text { management and improve } \\
\text { water security }\end{array}$ \\
\hline
\end{tabular}

Source: World Bank (2017). Vietnam - Country Partnership Framework, Table 2.

The CPF (paragraph 91) states that the government's detailed project investment plans are under development, and hence, the projects for which the government is seeking World Bank Group (WBG) support have yet to be determined. However, paragraph 56 of the CPF refers to strategic shifts in the WBG's engagement with Vietnam, away from single-issue engagements:

In general, the WBG will, during the CPF period, move away from single-issue, projectfocused engagements, toward support for the development of national platforms and integrated systems. Engagements that may have a demonstrative impact through applying innovative solutions and approaches will also be favored, and there will be an emphasis on improving efficiency, quality, and sustainability of investments and services. Identified strategic shifts in WBG engagement over the CPF period are:

- Comprehensive engagement to strengthen private sector development and participation across sectors

- Support to achieve financial sustainability of public services and transfers

- Support to ethnic minority poverty reduction through livelihood and income generation activities

- Multisector engagements to strengthen linkages between education and the labor market

- Support to promote and stimulate low carbon energy generation

\section{A.III.3 THE WORLD BANK'S MAXIMIZING FINANCE FOR DEVELOPMENT AGENDA}

MFD ${ }^{118}$ is the World Bank Group's new approach to systematically leverage all sources of finance, expertise, and solutions to support developing countries' sustainable growth. The World Bank recognizes that in embracing the SDGs, countries' resource needs surpass their own budgets and 
available donor funding. Hence, the World Bank tries to find ways to harness all possible sources of finance, innovation, and expertise in order to meet the SDG challenge.

Though the World Bank stresses that its MFD is a global effort among countries, international organizations, and financial institutions, the World Bank appears to be in the driver's seat. Indeed, in July 2017, the G20 finance ministers approved a set of principles that gave the World Bank Group and other MDBs a framework for increasing private investment to support countries' development objectives, which implies a much more coordinated approach of the MDBs to the public and private aspects of development.

The World Bank considers its support for policy and regulatory reforms as helping countries access private finance, which many countries could not get in the past due to a lack of the right institutions or markets. The World Bank also states that their instruments can help address risks for investors. The way the MFD works is that the World Bank considers a spectrum of solutions, private as well as public, whenever a project is presented to the World Bank. The World Bank has selected nine countries, which have already requested private sector funds to advance development projects, to be the initial pilot countries. The countries are:

- Vietnam;

- Cameroon (IDA-eligible, but also creditworthy for some IBRD borrowing);

- Côte d'Ivoire (graduated from IDA in FY1973, but re-entered IDA in FY1992 and currently lending from IDA only at blend terms);

- Egypt (graduated from IDA in FY1981, then re-entered IDA in FY1991, and graduated again in FY1999)

- Indonesia (graduated from IDA in FY1980, re-entered IDA in FY1999, and graduated again in FY2008)

- Iraq (has never been an IDA-eligible country);

- Jordan (graduated from IDA in FY1978);

- Kenya (IDA-eligible, but also creditworthy for some IBRD borrowing); and

- Nepal (IDA-only country).

According to the World Bank, ${ }^{119}$ the private sector priority approach formalized through the MFD has already shown results in Colombia, Madagascar, Afghanistan, Turkey, the Solomon Islands, and West Africa.

While the private sector has an important role to play in achieving the SDGs, there is a concern that the focus on the private sector, and even the spending of ODA to bring in the private sector, may distract from using ODA for priority public investments. There is also concern that this focus may incentivize the private sector to operate in sectors which are inappropriate, such as public services, and therefore exacerbate inequalities. We have to keep in mind that there are limits to private sector involvement, and that the costs and benefits of involving the private sector will need to be examined carefully.

\section{A.III.4 PROSPECTS FOR DEVELOPMENT FINANCE FROM BILATERAL CREDITORS}

As was shown in Figures 9 and 10 earlier, net aid flows to Vietnam are on a clearly declining trend for most bilateral donors. While some bilateral aid for Vietnam will likely continue for a while, the 
amounts will decline as more bilateral donors exit. The exit decisions are not simply based on Vietnam reaching a specific landmark, but based on donor-specific criteria and domestic politics in donor countries. As was detailed in the joint 2014 report by the United Nations Agencies in Vietnam, Delegation of the European Union to Vietnam, and the Ministry of Planning and Investment of Vietnam:120 "With the scaling back of assistance comes a clear shift of focus, from poverty reduction to trade and from financial transfers to a post-aid development partnership." Finally, as detailed in Box 5, new DAC rules on sovereign loans from DAC members being counted as ODA may have a major impact on Vietnam's future ODA from Japan and South Korea, who have provided most of their assistance via loans (not grants).

\section{Box 5: New DAC rules on sovereign loans from DAC members being counted as ODA}

At their High Level Meeting in December 2014, DAC members agreed to make-what they called-important improvements in the system. ${ }^{121}$ Whereas in the past the face value of both grants and concessional loans was counted as ODA, they agreed that only grants and the "grant portion" of concessional loans would be considered as ODA, starting in 2018.

This provides a more realistic comparison of loans and grants, and encourages the use of grants and highly concessional loans. The discount rate used in the calculation is also differentiated by developing country groups. Therefore, a loan to a LDC or other LIC will score more ODA than a loan provided under the same conditions extended to a MIC. This is supposed to provide an incentive to either give grants or to lend to poorer countries, as the funding cost of the loan and the increased risks for the provider are taken into account.

To better understand the implications of these changes for a LMIC such as Vietnam, we calculate the NPV of an illustrative example under previous and new rules. Based on the previous rules, a 10-year loan with the nominal amount of $\$ 500,000$ and an interest rate of 3.5 percent had an NPV of $\$ 374,698$, which implies that it had a grant element of at least 25 percent $(\$ 125,000)$, and hence, the whole loan was considered ODA (at least until repayments reduced that). However, under the new rules, which are now standard for reporting from 2018 onwards, the NPV of this loan would be $\$ 425,590$ due to the new discount rate (now only 7 percent, instead of the previous 10 percent). And given that the new minimum grant element for a LMIC is now at least 15 percent ( $\$ 75,000$ in this case), this loan would no longer qualify as ODA for a LMIC. The same loan would, however, qualify as ODA for a LMIC if the interest rate was 3 percent (instead of 3.5 percent) as that would reduce the NPV to $\$ 414,959$. However, based on the new rules, only the grant element of this loan $(\$ 85,041$ under the new rules) would be considered ODA (and repayments have no further impact).

Assuming that these rules will be put into practice, Vietnam is likely to see a massive reduction in ODA, though donors like Japan and South Korea may continue to provide their assistance as usual despite knowing that it will no longer count towards ODA.

\section{Japan}

Japan, which has been Vietnam's largest bilateral aid provider since 1995 is expected to continue to provide a mix of concessional and non-concessional loans to Vietnam. The latest Annual Report of the Japan International Cooperation (JICA) of 2017 praises Vietnam's progress during the last three decades but then stresses that Vietnam needs to develop further if it wants to sustain its progress, which can be interpreted as an intention to continue to support Vietnam:

Viet Nam needs to further develop infrastructure, increase industrial competitiveness, address environmental problems and climate change, and streamline administrative 
functions, among other issues. Aiming at achieving the goal of becoming a modern industrialized country, the Vietnamese government is putting priority on infrastructure development as well as economic and administrative reforms and human resources development.

In this regard, JICA is extending cooperation with a focus on (1) promotion of economic growth and strengthening international competitiveness; (2) response to vulnerability, the negative impacts brought by economic development; and (3) good governance. Specifically, JICA is extending cooperation over a broad range of fields, including infrastructure development, reforms of state-owned enterprises and the banking sector, enhancement of higher education and vocational training, improvement of the urban environment, countermeasures against climate change, promotion of high-value-added agriculture, improvement of health care, and improvement of the judiciary and administrative functions. ${ }^{122}$

\section{South Korea}

South Korea, which was Vietnam's second largest bilateral aid donor from 2012 to 2015, can also be expected to provide a mix of concessional and non-concessional loans to Vietnam in the future, though the provision of concessional loans may be phased out over time. The South Korean president, President Moon visited Vietnam in March 2018 and promised to provide aid for Vietnam's industrialization efforts, though no specific numbers have been mentioned. ${ }^{123}$ The South Korean Samsung Electronics factory in Thai Nguyen is Vietnam's largest firm, employing more than 60,000 people. ${ }^{124}$

\section{US}

The US, which was Vietnam's fourth largest bilateral donor in 2016 (in terms of net ODA) has a country development cooperation strategy via USAID that runs from 2014-2019. ${ }^{125}$ The subsequent strategy will be determined by USAID's new strategic approach, called Journey to Self-Reliance (which is summarized in Box 6 below).

\section{Germany}

Germany, which became Vietnam's second largest bilateral aid donor in 2016 (excluding the uncertain level of Chinese aid) is likely to continue to provide ODA, though it may shift its support towards the Kreditanstalt für Wiederaufbau (KfW), which provides mostly loans at close-toconcessional terms to countries all over the world. For 2017-2018, the volume of German development cooperation was $\$ 193.8$ million. ${ }^{126}$

\section{Australia}

The partnership between Australia and Vietnam extends across political, security, economic, and people-to-people activities. Australians born in Vietnam represent the sixth largest migrant community in Australia, and around 28,000 Vietnamese students enroll in education institutions in Australia each year. Vietnam is one of Australia's fastest-growing trade partners and is central to regional security in South-East Asia. Vietnam's further development as a strong trade and investment partner is in Australia's national interest and vital to the region's prosperity. ${ }^{127}$ With regards to aid, Australia's current Aid Investment Plan covers 2015-16 to 2019-20. The total Australian ODA for $2017-18$ is estimated to be $\$ 82.2$ million, while the total Australian ODA for 2018-19 is estimated at $\$ 84.2$ million. 


\section{Box 6: The Journey to Self-Reliance-USAID's new strategic approach}

USAID believes that two mutually reinforcing factors determine a country's self-reliance: commitment and capacity. Commitment refers to the degree to which a country's laws, policies, actions, and informal governance mechanisms (such as cultures and norms) support progress towards self-reliance. Capacity refers to how far a country has come in its journey of political, social, and economic development, including the ability to work across these sectors. ${ }^{128}$

In October 2018, USAID published their "Country Roadmaps," essentially their visualization of a set of 17 high-level indicators, which they feel best capture commitment and capacity. USAID hopes to use these roadmaps to plot a country's position on a self-reliance spectrum. The results of this will allow USAID to reorient support; inform country strategies; initiate dialogues with governments, implementing partners, and civil society, etc.; and signal when USAID might consider a strategic transition. According to the agency, the metrics are not intended to be determinative, push competition, used in isolation of other types of data, or to act as program indicators. ${ }^{129}$

The seven indicators or components measuring commitment are (1) the Liberal Democracy Index, (2) the World Justice Project Rule of Law Index, (3) the Economic Gender Gap Component, (4) a measure for Social Group Equality in Respect for Civil Liberties, (5) the Business Environment Component, (6) the Index of Economic Freedom, and (7) the Biodiversity and Habitat Protections Subcomponent, Environmental Performance Index.

The 10 indicator or components measuring capacity are (1) the Worldwide Governance Indicators, (2) a measure for the efficiency of the tax administration, (3) the safety and security component, (4) the Diagonal Accountability Index, (5) the Poverty Headcount Ratio (measured as a percentage of the population living on less than a PPP of $\$ 5$ per day), (6) the percentage of students attaining a minimum proficiency in reading at the end of primary school, (7) the child health indicator, (8) PPP-adjusted GDP per capita, (9) the Export Concentration Index, and (10) the Information and communication technology (ICT) use subcomponent of the technological readiness component.

\section{France}

Given France's colonial legacy in Vietnam, the country's ODA is of particular note. Though France's net aid flows dipped in 2015 (to $\$ 85$ million) and even more so in 2016 (to $\$ 41$ million), partly due to repayments of previously disbursed loans, France is expected to continue to provide ODA to Vietnam to the amount of about $\$ 247$ million per year. This aid will go to projects in infrastructure, agriculture, and education, and towards coping with climate change. Particularly, France is co-donor of the first subway line in Ho Chi Minh City, along with the ADB and European Investment Bank (EIB). This is the largest project that France has ever funded in Vietnam and carries an ODA of $€ 514$ million (\$634 million), including $€ 335$ million in preferential loans from the French Treasury and $€ 179$ million from the French Development Agency. ${ }^{130}$

\section{Ireland}

Ireland's objectives in Vietnam have been set out in Ireland's recent Vietnam Mission Strategy 2017-2020 (approved in May 2017), which supports the Government's Socio-Economic Development Plan 2016-2020. The new strategy has an indicative annual budget of $€ 10$ million, though this budget covers four countries: Vietnam, Cambodia, Lao PDR, and Myanmar. ${ }^{131}$ 


\section{Finland}

According to the Finnish Ministry of Foreign Affairs, ${ }^{132}$ Finland's grant-based bilateral development cooperation programs came to an end for Vietnam in 2018, and the focus of bilateral relations between Finland and Vietnam has now shifted towards mutually beneficial cooperation and more comprehensive partnerships. In order to move swiftly and efficiently from aid to trade, a wellplanned and efficiently executed transition strategy is needed. 


\section{ANNEX IV: VIETNAM'S DOMESTIC DEVELOPMENT FINANCE PORTFOLIO}

Vietnam's domestic development finance has traditionally come from government revenues, domestic loans, and domestic bonds, showing that domestic public resources are key. As there are no immediate constraints when the government borrows via domestic loans and domestic bonds, other than Vietnam becoming unsustainably indebted, this section focuses first on government revenues and taxes, and then on aid for DRM.

Based on the synthesis of Oxfam interviews with government officials, representatives from key donors (including from the World Bank, EU, and UNDP), and domestic research institutes, it is evident that during the last few years the GoV has replaced declining concessional financing with domestic loans and bonds. In 2017, of the total government borrowing, slightly over 60 percent came from domestic sources, while slightly less than 40 percent came from external sources. Looking forward, the GoV plans for about 70 percent to 75 percent of its total development finance to come from domestic sources. ${ }^{133}$

\section{A.IV.1 EVOLUTION OF GOVERNMENT REVENUES AND TAXES}

Vietnam's Tax Reform Strategy 2011-20 was approved by the Prime Minister in Decision 723 (dated May 17, 2011). The high-level objectives of the strategy are to secure stable revenue mobilization, reduce compliance costs for taxpayers, and fundamentally improve the business environment. The strategy is being implemented in two phases, 2011-15 and 2016-20. The key objective for tax policy reform is to make the tax system simple, effective, transparent, equitable, and relevant to the market economy. ${ }^{134}$ The emerging challenges the tax system faces were stated as follows:

The tax-to-GDP ratio declined from 22 percent in 2006 to 18 percent in 2013, mainly due to a decline in oil revenues as a result of falling oil prices and oil reserves. Of the difficulties, loss of trade-related tax revenue over the medium term will likely impact medium-term revenues and hence require enhancing income and domestic taxation. One of the key challenges is the existence of several non-neutralities or distortions in both tax policy and tax administration, and a lack of harmonization among taxes: multiplicity of rates, a large number of exemptions, and generous tax incentives. The capital mobility and the increased activity of foreign firms will require the removal of tax-induced burdens on enterprises, and the introduction of better international taxation measures to avoid transfer pricing. These challenges will be riskier in the context of an economic slowdown and high market volatility. ${ }^{135}$

Given that ODA has been decreasing and is overall projected to decrease further for Vietnam, international development organizations have stressed the importance of DRM to finance the still urgently needed development projects to reach the SDGs. However, as Figure 38 shows, both government revenues and tax revenues (as a percentage of GDP) indicate a declining trend, at 
least until 2014 for government revenues and at least until 2015 for tax revenues. The dark dotted line shows government revenues based on the IMF Fiscal Monitor (2016) database, and sits just below the IMF Fiscal Monitor (2018) database line, marked in blue.

Figure 38: Government expenditures, revenues, and tax revenues (percent of GDP)
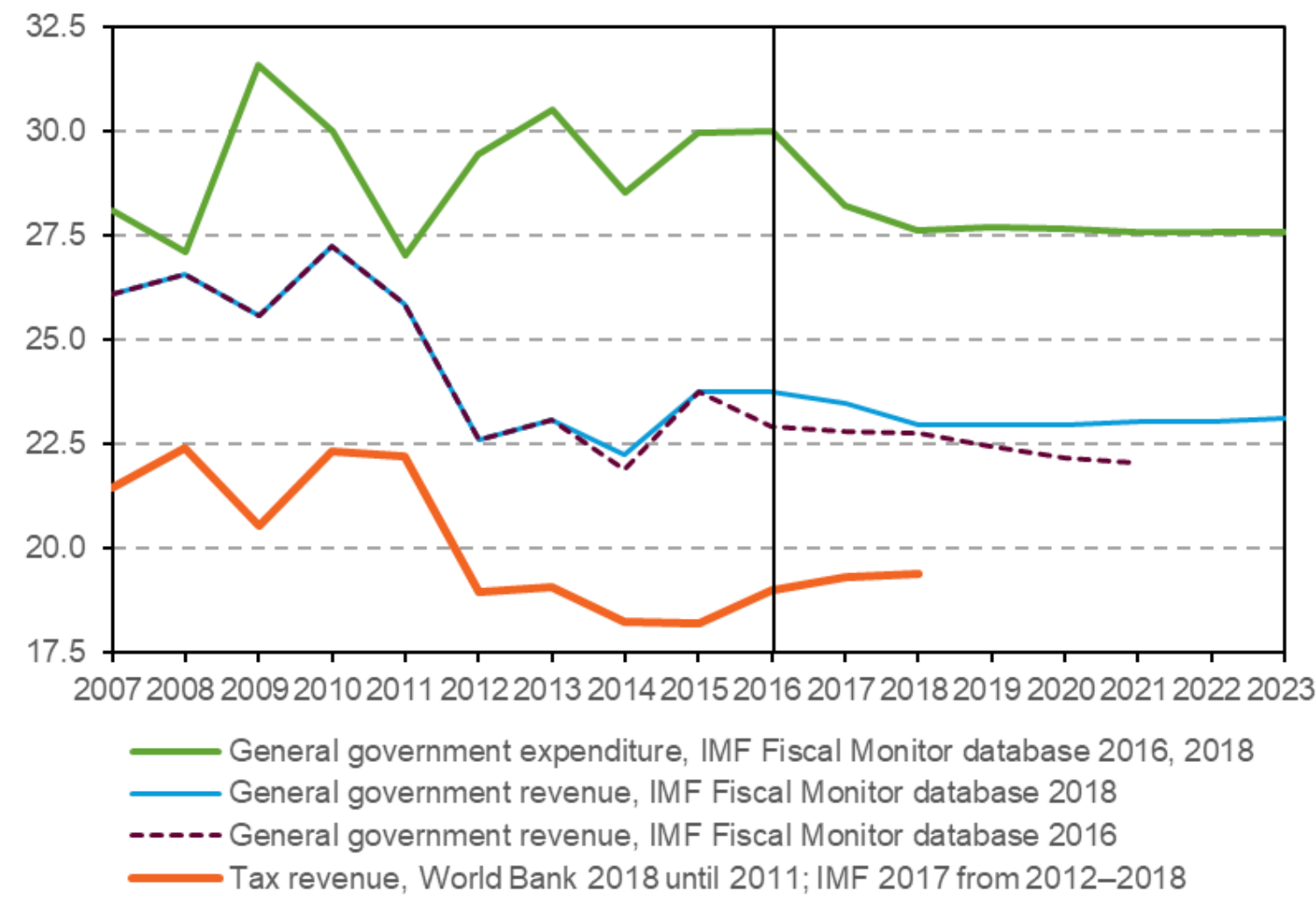

Source: Based on various data sources, see figure key above. ${ }^{136}$

Given the uncertainty involved in estimating government revenues, we show estimates from both the last two editions of the Fiscal Monitor database (2016 and 2018). While the 2018 estimates are slightly higher than the 2016 estimates, government revenues (as percent of GDP) show a declining trend from 2015 to 2018 in both cases. After all the emphasis on DRM, this is not the expected outcome. Box 7 compares Vietnam's government revenues with those of Bolivia and Sri Lanka.

While Vietnam's revenue-to-GDP ratio was projected to decrease after 2018 in the 2016 Fiscal Monitor database, the 2018 Fiscal Monitor database now projects a cumulative increase of 0.16 percentage points from 2018 to 2023 (or an average annual increase of 0.03 percentage points). This can hardly be considered a success in terms of tax reform.

In any case, even if using the slightly higher 2018 estimates of government revenues, the IMF's Fiscal Monitor database estimates a more or less persistent budget deficit of at least 4.5 percent until 2023 , which would need to be covered by either aid or loans. Assuming that aid will decline soon, an increasing share of this government deficit will need to be financed with non-concessional loans and bonds. As will be examined in the next section, this might threaten Vietnam's alreadyfragile fiscal debt sustainability, especially as Vietnam faces pressure to increase government expenditure to achieve the SDGs and cope with the demographic transition it has been facing since 2014 (an increase in its dependency ratio). 


\section{Box 7: Government revenues in Bolivia, Sri Lanka, and Vietnam}

Figure 39 compares the government revenues (as a percentage of GDP) of Vietnam with those of Bolivia and Sri Lanka. The figure shows that Vietnam's government revenues sit between those of Bolivia and Sri Lanka, with the differences across the three countries being considerable and persistent. Vietnam's government revenue-to-GDP ratio is "one of the highest in the region, because the method of calculation in Vietnam is different from that of many other countries. In Vietnam, the state budget revenues cover the state budget revenues from all government levels. In addition, the revenues from oils, land use fees, sale of stateowned houses have been included in the state budget revenues in Vietnam, while they are considered as the capital revenues (from selling natural resources)." ${ }^{137}$ Bolivia's revenue-toGDP ratio is even higher as the Bolivian government controls not only the country's resources, but also the whole economy.

Figure 39: General government revenue (percent of GDP) of Bolivia, Sri Lanka, and Vietnam

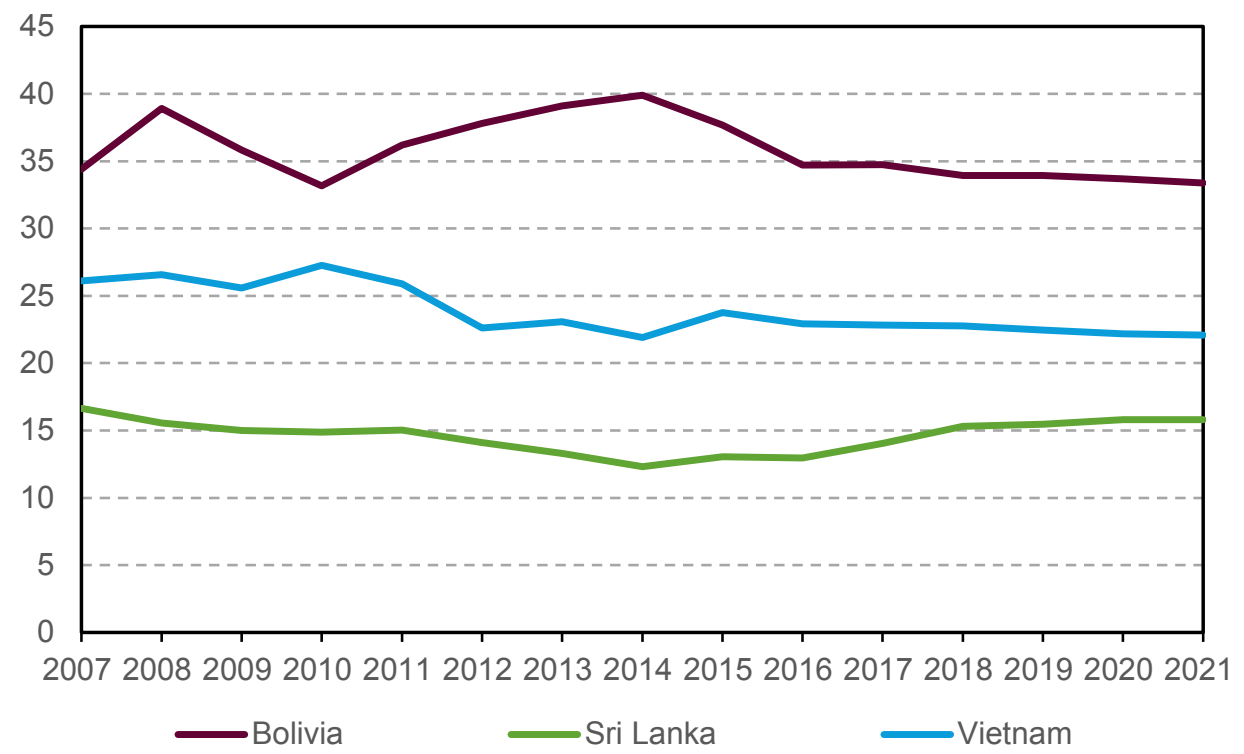

Source: IMF Fiscal Monitor database 2016 (given that the 2018 edition does not have data for Bolivia).

However, more interesting are the projected trends: While Bolivia's government revenues are, like those of Vietnam, projected to decline, Sri Lanka's government revenues are projected to increase considerably. Clearly, the focus on DRM seems to have different outcomes in different countries.

Though Vietnam's tax-to-GDP ratio increased in 2015 and 2016 (Figure 38), the trend before that was clearly negative. It will be very difficult for Vietnam to raise the tax-to-GDP ratio projected for 2017 and 2018 as taxes from trade are expected to decrease further. The percentage of trade tax revenues to trade has declined drastically from 2.83 percent in 2009 to only 0.97 percent in 2016 , even though the trade-to-GDP ratio increased from 135 percent in 2009 to 185 percent in 2016. Similarly, revenues from trade taxes to GDP have declined from 3.81 percent in 2009 to 1.79 percent in 2016. This decline in trade taxes has a relatively large impact on total revenues: The share of revenues from trade taxes in total government revenues has decreased from 18.4 percent in 2009 to only 9.4 percent in $2016 .{ }^{138}$ 
With further trade liberalizations in the making, revenues from trade taxes can be expected to decline further. For example, the new EU-Vietnam Free Trade Agreement, which was signed in June 2019, has been described as the most ambitious deal of its type ever concluded between the EU and a developing country, partly because it is expected to eliminate over 99 percent of customs duties on goods traded between Vietnam and the EU. ${ }^{139}$

While Vietnam has a progressive personal income tax (PIT) ${ }^{140}$ with tax rates from 5 percent (for annual incomes below VND60 million) to 35 percent (for annual incomes above VND960 million), the standard corporate income tax (CIT) is —at currently 20 percent-one of the lowest in the world, see Figure 40 . Vietnam has reduced the standard CIT six times during the last 20 years, from 35 percent in 1997 to 32.5 percent in 2000, then to 32 percent in 2001, 28 percent in 2004, 25 percent in 2009, 22 percent in 2014, and 20 percent in 2016. ${ }^{141}$ Though these reductions are consistent with a worldwide trend of CIT reductions, there seems to be a race to the bottom from which ultimately no country will benefit. Also, given that most other East Asian countries (including China, Indonesia, Japan, Lao PDR, and South Korea) have higher CIT rates, while Cambodia, Thailand, and Taiwan (a province of China) also have a 20 percent CIT rate, Vietnam seems to be more likely to be a leader in the race to the bottom than a follower.

Figure 40: CIT rates in selected economies (percent)

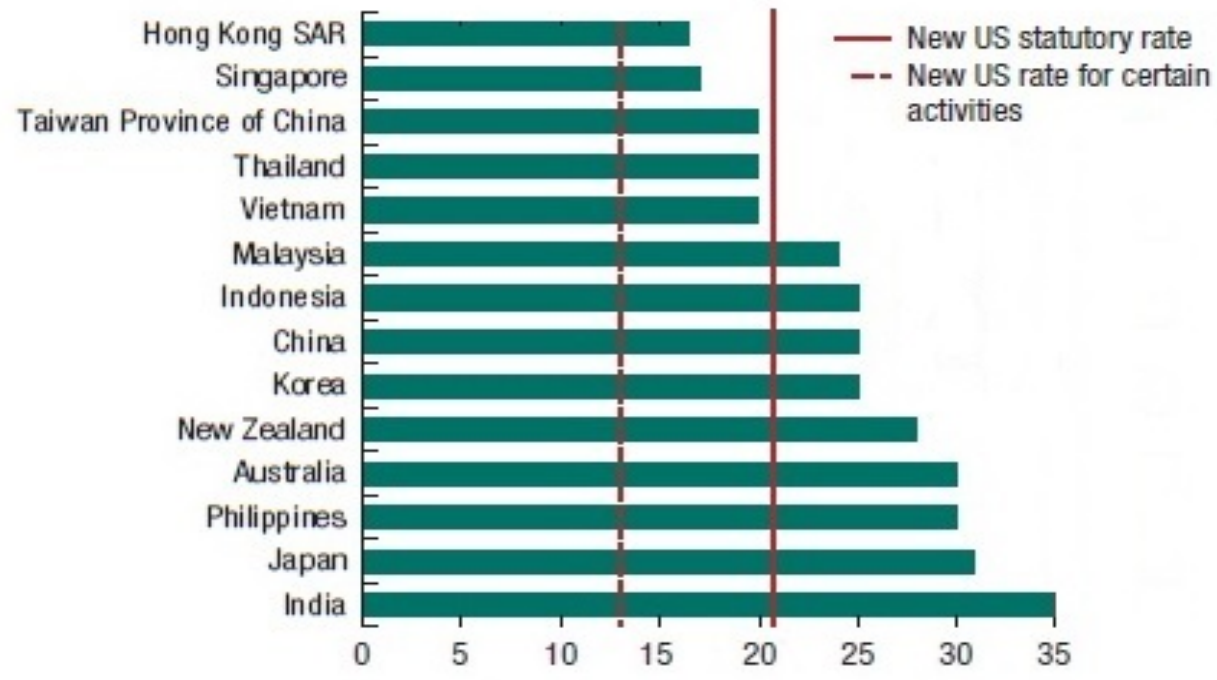

Source: Adapted based on IMF (2018) Regional Economic Outlook - Asia Pacific: Good Times, Uncertain Times, a Time to Prepare, Figure 1.2 .1 (p. 21).

There are more effective ways to boost competitiveness than reducing the CIT rate. For example, the World Economic Forum's Global Competitiveness Report 2017-2018 suggests that Vietnam could boost its competitiveness by closing gaps in innovation with countries at a similar stage of development, such as the Philippines. ${ }^{142}$ The report also states that Vietnam's competitiveness is largely driven by its market size. However, the Global Competitiveness Report 2017-2018 then states that significant improvements are necessary in Vietnam in all areas, notably meeting all basic requirements and increasing higher education levels, as firms perceive the lack of an educated workforce as a significant hurdle for doing business.

Finally, there is no wealth or property tax in Vietnam, which could be a very progressive tax and support Vietnam's goal to reduce inequality. As reported by Knight Frank (2017), in 2016, Vietnam had 14,300 millionaires (having assets of more than $\$ 1$ million), 610 multi-millionaires (having assets of more than $\$ 10$ million), and 200 super-rich (having assets of more than $\$ 30$ million). Knight Frank projects that by 2026, there will be 38,600 millionaires, 1,650 multi-millionaires, and 
540 super-rich people living in Vietnam. Calculations by Oxfam ${ }^{143}$ indicate that charging only these millionaires and multi-millionaires a tiny 0.1 percent wealth tax would have yielded tax revenues of $\$ 45$ million in 2016 and $\$ 121$ million in 2026 . Assuming there were about 335,000 people with assets of at least $\$ 100,000$ in 2016 , expanding the wealth tax to everybody with assets beyond $\$ 100,000$ would have provided a tax revenue of $\$ 112$ million in 2016 . While tiny in relation to overall tax revenues, such a wealth tax could provide substantial cash transfers to the approximately one million ultra-poor children living in Vietnam (as of 2016).

In conclusion, as total resources available to Vietnam are likely to decrease, Vietnam may get stuck in what has been called the "missing middle" of development finance: many of the previous IDA graduates saw their growth constrained as DRM failed to expand fast enough to compensate for the fall in ODA. ${ }^{144}$

\section{A.IV.2 EVOLUTION OF PUBLIC DOMESTIC BORROWING}

So far, the increased public borrowing via domestic loans and bonds has happened with considerably better terms. The maturity of government bonds has increased from 1.84 years in 2011 to 6.71 years in 2017 . Similarly, the average interest rate fell sharply from about 12.1 percent in 2011 to about 6 percent in 2018. The increased issuance of government bonds led to significant changes in the bond market. For example, the share of the commercial banks' bonds declined from 78 percent in 2016 , to 53 percent in 2017 . The rate of holding government bonds by security and insurance companies increased from 19.75 percent in 2016 to 45.95 percent in 2017. ${ }^{145}$ The GoV intends to improve the macroeconomic environment further gain the trust of the people and business community, who put their savings into idle resources like gold and foreign exchange. It has been estimated that these holdings amount to about 500 tons of gold (which are currently worth more than $\$ 20$ billion) and $\$ 10$ billion in foreign exchange. ${ }^{146}$

\section{A.IV.3 REVIEW OF AID FOR DRM}

Being aware of this "missing middle" in development finance, many development agencies have vowed to provide technical assistance programs to help Vietnam and others raise domestic revenues. At the Third Financing for Development (FfD) Conference in 2015, 20 of the world's largest donors signed the Addis Tax Initiative (ATI), committing to double their annual aid for DRM from $\$ 223.7$ million in 2015 to $\$ 447.5$ million by 2020 . While gross disbursements in 2016 accounted for $\$ 358$ million and commitments for $\$ 376$ million, this overall increase is driven primarily by two substantial loans by France. Excluding these loans, ATI development partners' support to DRM in 2016 slightly decreased in comparison to the 2015 baseline. Furthermore, the concentration of support has been more pronounced in 2016 than in 2015, as three countries (Indonesia, Armenia, and the Philippines) received almost half of total ODA for DRM.

Vietnam does not seem to be a major beneficiary of the ATI. There is no reference to Vietnam in the ATI Monitoring Brief 2016 (published in May 2018), nor is there any reference to Bolivia or Sri Lanka. ${ }^{147}$ Indonesia and Armenia were the two countries that received the two large loans from France, receiving $\$ 114$ million and $\$ 45$ million respectively. Countries that received the most ODA support provided by ATI development partners were the Philippines ( $\$ 13$ million), Afghanistan and Ghana (each $\$ 12$ million), Pakistan (\$8.4 million), Kenya (\$8.2 million), Uganda (\$6.9 million), Tanzania (\$5.9 million), and Zambia (\$5.1 million). The database underlying the May $2018 \mathrm{ATI}$ 
Monitoring Brief contains a total of 636 projects (with a total value of $\$ 291$ million). Only six of the 636 projects in the ATI database referred to Vietnam:

- two unspecified grants by the Japanese International Co-operation Agency summing to $\$ 924,000$;

- one regional project by UNDP/OECD Tax Inspectors Without Borders (TIWB) with a commitment of $\$ 885,000$;

- one project by the German government supporting Vietnam's National Green Growth Strategy to the amount of $\$ 642,000$;

- one three-year Oxfam project on Mobilizing Progressive Domestic Resources for Quality Public Services in three countries (of which one is Vietnam) with a planned budget of $\$ 387,000$, financed by the government of Finland;

- and one Study Visit by a delegation from Vietnam's Ministry of Natural Resources and Environment, which was supported by the Italian government with $\$ 1,018$.

However, Vietnam relies on many development partners for implementing proposed tax reforms and has received funds in the past from several donors, including the World Bank, the International Finance Corporation (IFC), the Japan International Cooperation Agency (JICA), IMF, and USAID. So far, the World Bank has been the most active partner in this reform area, providing analytical support and tax policy advice activities, largely via the World Bank-funded Tax Administration Modernization Project (TAMP), which was implemented during 2007-14 and financed with $\$ 80$ million from IDA and a $\$ 5$ million co-financing grant from Japan. However, the TAMP was recently cancelled due to the long-delayed implementation of its most important component, the Integrated Tax Administration Information System (ITAIS). ${ }^{148}$ 


\section{NOTES}

Unless otherwise stated, all URLs were last accessed August 2019.

1 Oxfam, VEPR, BTAP, Viet Nam Fair Tax Monitor 2017, Commitment to Reducing Inequality Index, 2018 https://www.oxfam.org/en/research/commitment-reducing-inequality-index-2018

2 IDA website. Available at: http://ida.worldbank.org/about/what-ida

3 DAC (2017, October 31). DAC High Level Communiqué. Available at: https://www.oecd.org/dac/DAC-HLM2017-Communique.pdf

4 OECD (2018). Cabo Verde Transition Finance Country Pilot. OECD Development Co-operation working papers. Available at: https://www.oecd-ilibrary.org/development/cabo-verde-transition-finance-countrypilot 1affcac6-en

5 USAID (2017, December 18). Statement from USAID Administrator Mark Green on the National Security Strategy. Available at: https://www.usaid.gov/news-information/press-releases/dec-18-2017-statementusaid-administrator-mark-green-national-security-strategy

6 Oxfam (2016). Accountability and Ownership: The role of aid in a post-2015 world. Available at: https://policy-practice.oxfam.org.uk/publications/accountability-and-ownership-the-role-of-aid-in-a-post$\underline{\text { 2015-world-619839 }}$

7 Government of Vietnam (2015). Country Report: 15 years achieving the Viet Nam Millennium Development Goals. Available at: http://www.vn.undp.org/content/vietnam/en/home/library/mdg/country-report-mdg$\underline{\text { 2015.html }}$

8 Calculations based on World Bank (2018), WDI/IDS database (covers data until 2014) and World Bank (2018), Poverty Report (provides data for 2016).

9 United Nations Development Program (UNDP) and Viet Nam Academy of Social Sciences (VASS) (2016). Growth that Works for All: Viet Nam human development report 2015 on inclusive growth. Available at: http://www.vn.undp.org/content/vietnam/en/home/library/poverty/human-development-report-viet-nam$\underline{2015 /}$

10 World Bank (2018). Climbing the Ladder: Poverty reduction and shared prosperity in Vietnam. Available at: https://www.worldbank.org/en/news/speech/2018/04/05/poverty-reduction-and-shared-prosperity-invietnam

11 Based on World Bank (2018), WDI/IDS database and the World Bank (2018), Poverty Report, the average reduction in the percentage of people living below the $\$ 5.50$ poverty line was 21.3 percent (not percentage points) for every two years between 2010 and 2016.

12 World Bank (2018). Poverty Report; Government of Vietnam (2015). Country Report: 15 years achieving the Viet Nam Millennium Development Goals. Available at: http://www.vn.undp.org/content/vietnam/en/home/library/mdg/country-report-mdg-2015.html

13 For further details see The Global Partnership for Effective Development Co-operation (2016). Vietnam: Monitoring profile - October 2016. Available at: http://effectivecooperation.org/wpcontent/uploads/2016/10/Viet Nam 14-10.pdf?s

14 Government of Vietnam (2016). Decision 251/QD-TTg on "Orientation toward attraction, management and use of ODA and concessional loans from foreign donors in 2016-2020 period." 
15 The term total investment capital (TIC) has been used by the GoV in Decision 251, which sets out how to attract, manage, and use ODA during 2016-2020. TIC focuses on investment expenditures (like the building of a new school) instead of consumption expenditures (like the payment of public servants).

16 Viet Nam News (2018, July 6). NGOs Gave VN \$4.3b Over Last Two Decades. Available at: https://vietnamnews.vn/politics-laws/451249/ngos-gave-vn-43b-over-last-twodecades.html\#xW12pO5Hht12Aub3.97

17 Calculated by author based on World Bank (2018) WDI/IDS database estimates for 2017 net ODA, and GoV (2018), Review the Implementation of Decree 12/2012/ND-CP on Registration and Management Activities Foreign Non-governmental Organizations in Vietnam.

18 For more information, please see the joint Oxfam, Irish Aid, DFID and iSEE report, Benchmark Assessment of Civil Society Space in Vietnam (2015), available at http://isee.org.vn/wpcontent/uploads/2018/11/benchmark-assessment-of-civil-society-space-in-vietnam..pdf

19 See EU (2014). EU Cooperation in Viet Nam: An enhanced response to the development challenges. The Multiannual Indicative Programme for Viet Nam 2014 - 2020. Available at: http://eeas.europa.eu/ archives/delegations/vietnam/documents/eu vietnam/20141113 mip en.pdf

Oxfam has been selected as an implementer in this program, but it is now at risk of cancellation because of significant delays.

20 This paragraph is based on an Oxfam interview with a senior EU representative in Vietnam, conducted in June 2018.

21 United Nations Agencies in Vietnam, Delegation of the European Union to Viet Nam, and Ministry of Planning and Investment of Vietnam (2014). Development Finance for Sustainable Development Goals in Middle-Income Vietnam: Financing Vietnam's Development: Meeting the new challenges. Box 1, p. 17. Available at: http://eeas.europa.eu/archives/delegations/vietnam/documents/eu_vietnam/ dev finance en.pdf

22 OECD (2017). Development Co-operation Report 2017: Data for development. Chapter 7, Figure 7.13. Available at: https://www.oecd-ilibrary.org/development/development-co-operation-report-2017 dcr-2017$\underline{\text { en }}$

23 World Bank (2018, April 5). Vietnam Continues to Reduce Poverty, According to WB Report. Available at: http://www.worldbank.org/en/news/press-release/2018/04/05/vietnam-continues-to-reduce-povertyaccording-to-world-bank-report

24 Oxfam (2019) False promises: How delivering education through public-private partnerships risks fuelling inequality instead of achieving quality education for all. Available at: https://www.oxfam.org/en/research/false-promises

25 World Bank (2018). WDI/IDS database.

26 World Bank (2018). World Development Report 2018: Learning to realize education's promise. Washington, DC: World Bank. Available at: https://www.openknowledge.worldbank.org/handle/ $\underline{10986 / 28340}$

27 P.W. Glewwe et al. (2017). What Explains Vietnam's Exceptional Performance in Education Relative to Other Countries? Analysis of the 2012 PISA Data. Paper presented at the RISE Annual Conference, Center for Global Development, Washington, DC, June 15-16.

28 C. Bodewig et al.(2014). Skilling Up Vietnam: Preparing the workforce for a modern market economy. Available at: http://documents.worldbank.org/curated/en/283651468321297015/pdf/ 888950PUB0Box30Iso0829400June172014.pdf 
29 The Global Partnership for Effective Development Co-operation (2016). Vietnam: Monitoring profile October 2016. Available at: http://effectivecooperation.org/wp-content/uploads/2016/10/Viet Nam 1410.pdf?s

30 ADB (2017). Asian Development Outlook (ADO) 2017: Transcending the middle-income challenge. Available at: https://www.adb.org/sites/default/files/publication/237761/ado-2017.pdf

31 J. Sachs et al. (2017). SDG Index and Dashboards Report 2017. New York: Bertelsmann Stiftung and Sustainable Development Solutions Network (SDSN), p.382. Available at: http://www.sdgindex.org/assets/files/2017/2017-SDG-Index-and-Dashboards-Report-regions.pdf

32 This is also supported by Pallas and Nguyen (2018). Donor Withdrawal and Local Civil Society Organizations: An Analysis of the HIVIAIDS Sector in Vietnam. Development Policy Review, 36(1), 131-51.

33 J. Sachs et al. (2017). SDG Index and Dashboards Report 2017. New York: Bertelsmann Stiftung and Sustainable Development Solutions Network (SDSN), p. 382. Available at: http://www.sdgindex.org/assets/files/2017/2017-SDG-Index-and-Dashboards-Report-regions.pdf

34 G. Hutton and M. Varughese (2016). The Costs of Meeting the 2030 Sustainable Development Goal Targets on Drinking Water, Sanitation, and Hygiene. Washington, DC: The World Bank. Available at: http://documents.worldbank.org/curated/en/415441467988938343/pdf/103171-PUB-Box394556B-PUBLICEPI-K8543-ADD-SERIES.pdf

35 World Bank (2018). WDI/IDS database

36 See details in World Bank (2008). World Development Report 2008. Agriculture for Development. Available at: http://siteresources.worldbank.org/INTWDR2008/Resources/2795087-1192111580172/WDROver2008ENG.pdf

37 Thi Thuy Hang Truong (2008). Women's Leadership in Vietnam: Opportunities and Challenges. Signs, 34(1), 16-21.

38 Ibid.

39 Viet Nam News (2018, January 24). Despite High Number of Female Vietnamese Labourers, Inequality Persists. Available at: http://vietnamnews.vn/society/421772/despite-high-number-of-female-vietnameselabourers-inequality-persists.htm|\#Ud7QrJMAxm5doSft.97

40 Ibid.

41 The IMF's 2018 Staff Report projected Vietnam's total public debt for 2018 to be 57.8 percent, after 2017 experienced an exceptionally high growth rate according to official data and subsequent revisions in GDP growth projections.

42 The National Action Plan to implement the 2030 Agenda for SDGs (SDG NAP) was promulgated as per Decision 633 (dated 10 May, 2017) of the Prime Minister, in which the 17 SDGs for Vietnam to achieve by 2030 were set, including 115 specific targets.

43 World Bank and Ministry of Planning and Investment of Vietnam (2016). Vietnam 2035: Toward prosperity, creativity, equity, and democracy. Washington, DC: World Bank, p. 30. Available at: https://openknowledge.worldbank.org/handle/10986/23724

44 Gunter, Bernhard G., Humberto Lopez, Krishnan Ramadas, and Quentin Wodon(2002). SimSIP Debt: $A$ Simulation Tool for Analyzing Debt Sustainability. Latin America and the Caribbean Region. Washington, DC: World Bank.

This simulation module was available on the World Bank website for about a decade and used for many DSAs outside the World Bank. It should be stressed that there is no difference in the methodology this 
module uses for calculating future debt values compared with the IMF debt projection module. What is different (and hence explains different results from different DSAs) are the various assumptions and the time frame for the variables on which the projection is made (like NPV debt or nominal debt) etc.

45 The joint IMF-World Bank DSA framework uses different debt sustainability indicators, depending on if the country is a low- or middle-income country. Given that most of the LICs' debt is concessional debt, the focus is on NPV debt indicators. On the other hand, as most of the MICs' debt is non-concessional, nonNPV debt indicators are used for DSAs of MICs.

46 A table comparing all the macroeconomic indicators and assumptions for the two scenarios is available upon request.

47 This conclusion can be drawn based on experience even though we have not explicitly shown results for different GDP growth rates.

48 See https://selfreliance.usaid.gov/

49 N. Lea and S. Dercon (2016). Benchmarking Aid Allocation: Is the global and multilateral aid allocation poverty-focused? United Kingdom: Department for International Development, Chief Economist's Office.

50 Oxfam (2016). Accountability and Ownership: The role of aid in a post-2015 world. Available at: https://policy-practice.oxfam.org.uk/publications/accountability-and-ownership-the-role-of-aid-in-a-post2015-world-619839

51 R. Kanbur and A. Sumner (2012). Poor Countries or Poor People? Development assistance and the new geography of global poverty. Journal of International Development, 24, 686-95.

See also A. Sumner (2012). Where Will the World's Poor Live? An update on global poverty and the new bottom billion. Washington, DC: Center for Global Development. Available at: http://www.cgdev.org/sites/default/files/1426481 file Sumner where in the world FINAL 0.pdf

52 Based on data provided in G-M. Lange et al. (2018). The Changing Wealth of Nations 2018. Washington, DC: World Bank. Available at: https://openknowledge.worldbank.org/handle/10986/29001

53 Like most multilateral aid agencies, UNDP Vietnam provides a variety of information, see for example: http://www.vn.undp.org/content/vietnam/en/home/ourwork/environmentclimate/overview.html

54 See pp. i-ii of World Bank (2016). Review of IDA's Graduation Policy. Available at: http://documents.worldbank.org/curated/en/605191468191042391/Review-of-IDA-s-graduation-policy

55 Ibid.

56 Ibid.

57 IDA. IDA Graduates. Available at: http://ida.worldbank.org/about/ida-graduates

58 IDA. IDA Borrowing Countries. Footnote 1. Available at: http://ida.worldbank.org/about/borrowing-countries

59 See footnote b of Table 3 of the World Bank (2017). Country Partnership Framework for the Socialist Republic of Vietnam for the Period FY18-FY22. P. 40. Available at: https://elibrary.worldbank.org/doi/abs/10.1596/27146. Replicated as Table 7 in this report.

60 Economic and Social Council (ECOSOC) (2018). Forum on Financing for Development Follow-up. New York, April 23-28, 2018. Adoption of the Intergovernmentally Agreed Conclusions and Recommendations, Final Draft Outcome, No. E/FFDF/2018/L.2 (April 19, 2018). Available at: https://undocs.org/E/FFDF/2018/L.2

61 G. Yamey et al. (2018). Transitioning From Foreign Aid: Is the next cohort of graduating countries ready? Available at: http://centerforpolicyimpact.org/wp-content/uploads/sites/18/2018/03/Transition-from-foreignaid DukeCPIGH-Working-Paper-final.pdf 
62 A. Prizzon et al. (2017). Moving Away From Aid? The case of Indonesia. London: Overseas Development Institute (ODI). Available at: https://www.odi.org/publications/10737-indonesia-debt-management-micmiddle-income-countries-aid

63 R. Greenhill et al. (2013). The Age of Choice: Developing countries in the new aid landscape. A synthesis report. London: ODI. Available at: https://www.odi.org/publications/7163-age-choice-developing-countriesnew-aid-landscape

64 S. Rose et al. (2017). Working Itself Out of a Job: USAID and smart strategic transitions. Available at: https://www.cgdev.org/sites/default/files/working-itself-out-job-usaid-and-smart-strategic-transitions.pdf

65 See, for example, various IMF Fiscal Monitor Reports and Figure 3 (p. 25) of the IMF's Vietnam Staff Report for the 2018 Article IV Consultation. Further details are also provided in Annex IV.

66 Eurodad (2018, October 7). History RePPPeated - How public-private partnerships are failing. Available at: https://eurodad.org/HistoryRePPPeated

67 Government of Vietnam (2015). Country Report: 15 years achieving the Viet Nam Millennium Development Goals. Available at: http://www.vn.undp.org/content/vietnam/en/home/library/mdg/country-report-mdg2015.html

68 In the case of Vietnam, IDA's disbursements peaked in 2014 (see Figure 6), just two and a half years before graduating from IDA.

69 T. Kikuchi et al. (2018). The Effects of Mega-Regional Trade Agreements on Vietnam. Journal of Asian Economics, 55, 4-19.

70 Calculations based on World Bank (2018), WDI/IDS database (which covers data until 2014) and the World Bank (2018), Poverty Report (which provides data for 2016).

71 Based on World Bank (2018), WDI/IDS database and the World Bank (2018), Poverty Report, the average reduction in the percentage of below living below the $\$ 5.50$ poverty line was 21.3 percent (not percentage points) for every two years between 2010 and 2016.

72 R. Anand et al (2014). Potential Growth in Emerging Asia. Washington, DC: International Monetary Fund (IMF), p. 13. Available at: https://www.imf.org/en/Publications/WP/Issues/2016/12/31/Potential-Growth-inEmerging-Asia-41198

73 T. Kikuchi et al. (2018). The Effects of Mega-Regional Trade Agreements on Vietnam. Journal of Asian Economics, 55, 4-19.

74 Asian Development Bank (2017). Meeting Asis's Infrastructure needs. Available at https://www.adb.org/sites/default/files/publication/227496/special-report-infrastructure.pdf

75 Government of Vietnam (2015). Country Report: 15 years achieving the Viet Nam Millennium Development Goals. Available at: http://www.vn.undp.org/content/vietnam/en/home/library/mdg/country-report-mdg2015.html

76 UNDP and VASS (2016). Growth that Works for All: Viet Nam human development report 2015 on inclusive growth. Available at: http://www.vn.undp.org/content/vietnam/en/home/library/poverty/human-developmentreport-viet-nam-2015/

77 World Bank (2017, December 11). Vietnam Sees Stronger Growth Momentum. Available at: http://www.worldbank.org/en/news/press-release/2017/12/11/vietnam-sees-stronger-growth-momentum

78 For further details see The Global Partnership for Effective Development Co-operation (2016). Vietnam: Monitoring profile - October 2016. Available at: http://effectivecooperation.org/wpcontent/uploads/2016/10/Viet Nam 14-10.pdf?s 
79 World Bank (2018), WDI/IDS database.

80 The HDI is based on three dimensions: a long and healthy life, knowledge, and a decent standard of living.

81 Given that the World Bank (2018) Poverty Assessment did not provide data for the 2016 value for the $\$ 5.50$ a day poverty headcount ratio, it has been estimated based on the relative reduction in the $\$ 3.20$ a day headcount ratio from 2014 to 2016 .

82 World Bank (2018). Climbing the Ladder: Poverty reduction and shared prosperity in Vietnam. Available at: https://www.worldbank.org/en/news/speech/2018/04/05/poverty-reduction-and-shared-prosperity-invietnam

83 These challenges and recommendations are adopted from the World Bank (2018), Poverty Report.

84 United Nations Agencies in Vietnam, Delegation of the European Union to Viet Nam, and Ministry of Planning and Investment of Vietnam (2014). Development Finance for Sustainable Development Goals in Middle-Income Vietnam: Financing Vietnam's Development: Meeting the new challenges. Available at: http://eeas.europa.eu/archives/delegations/vietnam/documents/eu vietnam/dev finance en.pdf

85 Government of Vietnam (2015). Country Report: 15 years achieving the Viet Nam Millennium Development Goals. Available at: http://www.vn.undp.org/content/vietnam/en/home/library/mdg/country-report-mdg$\underline{2015 . h t m l}$

86 lbid.

87 Dang Thi Thu Hoai (2018). Does Horizontal Inequality Matter in Vietnam? Social Indicators Research. Available at: https://doi.org/10.1007/s11205-018-1896-1

88 See M. Lawson and M. Martin (2018). Commitment to Reducing Inequality Index. Available at: https://www.oxfam.org/en/research/commitment-reducing-inequality-index-2018

89 World Economic Forum (2017). The Global Gender Gap Report 2017. Cologny/Geneva: World Economic Forum. Available at: http://www3.weforum.org/docs/WEF GGGR 2017.pdf

90 World Bank (2018). Climbing the Ladder: Poverty reduction and shared prosperity in Vietnam. Available at: https://www.worldbank.org/en/news/speech/2018/04/05/poverty-reduction-and-shared-prosperity-invietnam

91 Ibid.

92 I.A. Chowdhury et al. (2018). Gender Gap in Earnings in Vietnam: Why do Vietnamese women work in lower paid occupations? Available at: http://documents.worldbank.org/curated/en/685791521537975174/ pdf/124438-BRI-19-3-2018-11-16-51-EAPVietnamBriefWEBv.pdf

93 Viet Nam News (2017, September 16). Improved Status of Women Vital for Economic Growth: Deputy PM. Available at: http://vietnamnews.vn/society/393861/improved-status-of-women-vital-for-economic-growthdeputy-pm.htm|\#l2FmFC2zitvippYx.97

94 K. Malhotra (2017, October 20). Gender Inequality Slows VN Economy. Viet Nam News. Available at: http://vietnamnews.vn/opinion/405824/gender-inequality-slows-vn-economy.html\#sSR0CUiLzC9YS1gi.97

95 International Labour Organization and Navigos Search (2015, March). Gender Equality in recruitment and promotion practices in Viet Nam. Available at https://www.ilo.org/wcmsp5/groups/public/---asia/---robangkok/---ilo-hanoi/documents/publication/wcms 349666.pdf

96 Viet Nam News (2018, January 24). Despite High Number of Female Vietnamese Labourers, Inequality Persists. Available at: http://vietnamnews.vn/society/421772/despite-high-number-of-female-vietnameselabourers-inequality-persists.htm|\#Ud7QrJMAxm5doSft.97 
97 Ibid.

98 The Global Partnership for Effective Development Co-operation (2016). Vietnam: Monitoring profile October 2016. P. 3. Available at: http://effectivecooperation.org/wp-content/uploads/2016/10/Viet Nam 1410.pdf?s. See Indicator 8, Gender Empowerment.

99 Viet Nam News (2018, January 27). 58\% of Wed Women in VN Abused: Study. Available at: http://vietnamnews.vn/society/421886/58-of-wed-women-in-vn-abused-study.html\#31vpA2BleX7WgBr6.97

100 Thi Kieu Van Tran et al. (2018). Gender Differences in Formal Credit Approaches: Rural households in Vietnam. Asian-Pacific Economic Literature, 32(1) (May), 131-38.

101 A. Demirguc-Kunt et al. (2018). Global Findex Database 2017: Measuring financial inclusion and the fintech revolution. Washington, DC: World Bank. Available at: https://www.openknowledge.worldbank.org/handle/10986/29510

102 World Bank Group (2018). Women, Business and the Law 2018. Washington, DC: World Bank. Available at: https://www.openknowledge.worldbank.org/handle/10986/29498

103 Ibid., p. 41.

104 Oxfam (2018). Social Mobility and Equality of Opportunity in Vietnam: Trends and impact factors. Available at https://vietnam.oxfam.org/policy paper/social-mobility-and-equality-opportunity-vietnam-trends-andimpact-factors

105 United Nations Agencies in Vietnam, Delegation of the European Union to Viet Nam, and Ministry of Planning and Investment of Vietnam (2014). Development Finance for Sustainable Development Goals in Middle-Income Vietnam: Financing Vietnam's Development: Meeting the new challenges. P. 6. Available at: http://eeas.europa.eu/archives/delegations/vietnam/documents/eu vietnam/dev finance en.pdf

106 World Bank. World Bank's Private Participation in Infrastructure Database. Available at: https://ppi.worldbank.org/data. Accessed on June 14, 2018.

107 M. J. Romero (2015). What Lies Beneath? A critical assessment of PPPs and their impact on sustainable development. Available at: http://eurodad.org/files/pdf/559e6c832c087.pdf

108 The scale and nature of Gavi's support changes as GNI per capita increases over time. From the beginning of Gavi support, governments are expected to co-finance vaccines by financing a fraction of the needed doses. Gradually, as national income per capita levels grow, co-financing levels for governments increase. Gavi's detailed eligibility and transition policy can be found at: https://www.gavi.org/about/Program-policies/eligibility-and-transition/

109 https://trade.ec.europa.eu/tradehelp/everything-arms

110 United Nations Conference on Trade and Development. UN recognition of Least Developed Countries (LDC). Available at: http://unctad.org/en/Pages/ALDC/Least\%20Developed\%20Countries/UN-recognitionof-LDCs.aspx

111 Asian Development Bank (2016). Viet Nam: Country Partnership Strategy (2016-2020). Paragraph 23. Available at: https://www.adb.org/documents/viet-nam-country-partnership-strategy-2016-2020

112 CPA is all aid programmable to a country, even if it has not been disbursed; see https://data.oecd.org/oda/country-programmable-aid-cpa.htm

113 Based on the World Bank's (2015) CPF for Bolivia, p. 8.

114 According to the World Bank's (2016) CFP for Sri Lanka, pp. 8-9.

115 Asian Development Bank (2016). Viet Nam: Country Partnership Strategy (2016-2020). Paragraph 35. 
Available at: https://www.adb.org/documents/viet-nam-country-partnership-strategy-2016-2020

116 Ibid., paragraph 23.

117 World Bank Group (2017). Vietnam - Country Partnership Framework for the Period FY18-FY22. Washington, DC: World Bank. Available at: http://documents.worldbank.org/curated/en/173771496368868576/Vietnam-Country-partnershipframework-for-the-period-FY18-FY22

118 World Bank. Maximizing Finance for Development (MFD). Overview. Available at: http://www.worldbank.org/en/about/partners/maximizing-finance-for-development

119 World Bank. Maximizing Finance for Development (MFD). Country-level interventions. Available at: http://www.worldbank.org/en/about/partners/maximizing-finance-for-development\#2

120 United Nations Agencies in Vietnam, Delegation of the European Union to Viet Nam, and Ministry of Planning and Investment of Vietnam (2014). Development Finance for Sustainable Development Goals in Middle-Income Vietnam: Financing Vietnam's Development: Meeting the new challenges. Box 1, p. 17. Available at: http://eeas.europa.eu/archives/delegations/vietnam/documents/eu vietnam/ dev finance en.pdf

121 OECD Development Assistance Committee (DAC) (2015). Why Modernise Official Development Assistance? Flyer provided at the Third International Conference on Financing for Development in Addis Ababa (July 2015). Available at: http://www.oecd.org/dac/financing-sustainabledevelopment/Addis\%20flyer\%20-\%200DA.pdf

122 Excerpts from pp. 29-30 of Japan International Cooperation Agency (JICA) (2017). JICA 2017 Annual Report. Tokyo: JICA. Available at: https://www.jica.go.jp/english/publications/ reports/annual/2017/c8h0vm0000bws721-att/2017 all.pdf

123 Tuổi Trẻ News (2018, March 23). South Korea Promises Aid For Vietnam's Industrialization Efforts Available at: https://tuoitrenews.vn/news/politics/20180323/south-korea-promises-aid-for-vietnamsindustrialization-efforts/44699.htm

124 The Economist (2018, April 12). Why Samsung of South Korea is the Biggest Firm in Vietnam. Available at: https://www.economist.com/asia/2018/04/12/why-samsung-of-south-korea-is-the-biggest-firm-in-vietnam

125 USAID (2014). Country Development Cooperation Strategy for Vietnam 2014-2019. Available at: https://www.usaid.gov/sites/default/files/documents/1861/CDCS Vietnam 2014-2019 final.pdf

126 Using an end 2017 \$/EURO exchange rate of 1.2003; https://www.bmz.de/en/countries regions/asien/vietnam/profil.html

127 Australian Government. Development assistance in Vietnam. Available at: http://dfat.gov.au/geo/vietnam/development-assistance/Pages/development-assistance-in-vietnam.aspx

128 https://selfreliance.usaid.gov/docs/USAID Self-Reliance Metrics FY 2019 Methodology Guide.pdf

129 USAID. The Journey to Self-Reliance: Country roadmaps. Available at: https://selfreliance.usaid.gov/

130 Vietnam Investment Review (2018, January 25). Strengthening French-Vietnamese Co-Operation in Infrastructure and Satellite Development. Available at: http://www.vir.com.vn/strengthening-frenchvietnamese-co-operation-in-infrastructure-and-satellite-development-55874.html

131 See further details at Irish Aid. Vietnam. Available at: https://www.irishaid.ie/what-we-do/countries-wherewe-work/our-partner-countries/vietnam/

132 https://um.fi/development-cooperation-vietnam

133 Including from the Ministry of Finance (MoF), the Ministry of Planning and Investment (MPI), the National 
Assembly's Committee of Finance and Budget Affairs (CFBA), and Vietnam's Bank for Social Policies (VBSP).

134 Government of Vietnam (2015). Tax Policy and Administration Reform. Posted on the Ministry of Finance website on December 30, 2015. Paragraph 3. Available at: http://www.mof.gov.vn/webcenter/portal/mof/r/lvtc/htqt/pfgp/dopfpg/dopfpg chitiet?dDocName=MOF14945 0\&dID=3172\& afrLoop=3560738605089389\#!\%40\%40\%3F afrLoop\%3D3560738605089389\%26dDocNa me\%3DMOF149450\%26dID\%3D3172\%26showFooter\%3Dfalse\%26showHeader\%3Dfalse \%26 adf.ctrlstate\%3D44j5y0a1p 4

135 lbid., Paragraph 6.

136 Actual data on government expenditures, revenues, and taxes are only available until 2016; data shown beyond 2016 (marked with the vertical line) are either estimates or projections. The 2017 and 2018 data for tax revenues have been taken from the IMF (2017), Staff Report on Vietnam; the estimates for 2017 onwards for government expenditures have been taken from the last two editions (2016 and 2018) of the IMF Fiscal Monitor database.

137 United Nations Agencies in Vietnam, Delegation of the European Union to Viet Nam, and Ministry of Planning and Investment of Vietnam (2014). Development Finance for Sustainable Development Goals in Middle-Income Vietnam: Financing Vietnam's Development: Meeting the new challenges. P. 11. Available at: http://eeas.europa.eu/archives/delegations/vietnam/documents/eu vietnam/dev finance en.pdf

138 Based on World Bank (2018) WDI / IDS database.

139 European Parliament Think Tank (2018, February 14). International Agreements in Progress: EU-Vietnam Free Trade Agreement. Available at: http://www.europarl.europa.eu/thinktank/en/ document.html?reference=EPRS BRI(2018)614702

140 The PIT law took effect on January 1, 2009, replacing the previous ordinance and regulations covering Income Tax of High-Income Earners.

141 K. Pomerleau (2014, August 20). Corporate Income Tax Rates around the World, 2014. Available at: https://taxfoundation.org/corporate-income-tax-rates-around-world-2014/

142 See p. 26 of World Economic Forum (2018), The Global Competitiveness Report 2017-2018.

143 The assumptions underlying these calculations are relatively conservative: Using the number of millionaires, multi-millionaires and super-rich as given by Knight Frank (2017), it is assumed that the average wealth of a millionaire is $\$ 2$ million, the average wealth of a multi-millionaire is $\$ 15$ million, and the average wealth of an ultra-rich person is $\$ 35$ million.

144 See H. Kharas, et al (2014). Financing the Post-2015 Sustainable Development Goals: A rough roadmap. Available at: https://www.odi.org/sites/odi.org.uk/files/odi-assets/publications-opinion-files/9374.pdf

145 Sai Gon Economic Times cited MOF Minister Dinh Tien Dung's speech at the National Assembly session on May 26, 2018 on restructuring the state budget.

146 Vietam Net (2017, November 16). Thống đốc huy động 500 tấn vàng trong dân như thế nào? Available at: http://vietnamnet.vn/vn/thoi-su/quoc-hoi/thong-doc-huy-dong-500-tan-vang-trong-dan-nhu-the-nao411358.html

147 Addis Tax Initiative (ATI) and International Tax Compact (ITC) (2018). ATI Monitoring Brief 2016: ATI Commitment 1. Bonn: ITC). Available at: https://www.addistaxinitiative.net/resource/ati-monitoring-brief2016-ati-commitment-1

148 Government of Vietnam (2015). Tax Policy and Administration Reform. Posted on the Ministry of Finance website on December 30, 2015. 


\section{Oxfam Discussion Papers}

Oxfam Discussion Papers are written to contribute to public debate and to invite feedback on development and humanitarian policy issues. They are 'work in progress' documents, and do not necessarily constitute final publications or reflect Oxfam policy positions. The views and recommendations expressed are those of the author and not necessarily those of Oxfam. The paper was commissioned by Andrew Wells Dang, Hoa Quynh, Nadia Daar and Tariq Ahmad. Research was conducted by Bernhard Gunter with significant contributions by the Oxfam in Vietnam country team and Trịnh Tiến Dũng.

For more information, or to comment on this paper, email Tariq.Ahmad@oxfam.org

(c) Oxfam International October 2019.

This publication is copyright but the text may be used free of charge for the purposes of advocacy, campaigning, education, and research, provided that the source is acknowledged in full. The copyright holder requests that all such use be registered with them for impact assessment purposes. For copying in any other circumstances, or for re-use in other publications, or for translation or adaptation, permission must be secured and a fee may be charged. Email policyandpractice@oxfam.org.uk.

The information in this publication is correct at the time of going to press.

Published by Oxfam GB for Oxfam International under ISBN 978-1-78748-501-3 in October 2019.

DOI: $10.21201 / 2019.5013$

Oxfam GB, Oxfam House, John Smith Drive, Cowley, Oxford, OX4 2JY, UK.

\section{OXFAM}

Oxfam is an international confederation of 19 organizations networked together in more than 90 countries, as part of a global movement for change, to build a future free from the injustice of poverty. Please write to any of the agencies for further information, or visit www.oxfam.org.

Oxfam America (www.oxfamamerica.org)

Oxfam Australia (www.oxfam.org.au)

Oxfam-in-Belgium (www.oxfamsol.be)

Oxfam Brasil (www.oxfam.org.br)

Oxfam Canada (www.oxfam.ca)

Oxfam France (www.oxfamfrance.org)

Oxfam Germany (www.oxfam.de)

Oxfam GB (www.oxfam.org.uk)

Oxfam Hong Kong (www.oxfam.org.hk)

Oxfam IBIS (Denmark) (www.oxfamibis.dk)

Observer: KEDV (Oxfam Turkey)
Oxfam India (www.oxfamindia.org)

Oxfam Intermón (Spain) (www.oxfamintermon.org)

Oxfam Ireland (www.oxfamireland.org)

Oxfam Italy (www.oxfamitalia.org)

Oxfam Mexico (www.oxfammexico.org)

Oxfam New Zealand (www.oxfam.org.nz)

Oxfam Novib (Netherlands) (www.oxfamnovib.nl)

Oxfam Québec (www.oxfam.qc.ca)

Oxfam South Africa (www.oxfam.org.za) 